\title{
THE ARNOLD NEWMAN COLLECTION \\ OF PHOTOGRAPHS \\ AT THE ART GALLERY OF ONTARIO \\ FINDING AID
}

by
Sean Fraser Corscadden, BFA, Mount Allison University, 2009

A Thesis Project

Presented to Ryerson University and the Art Gallery of Ontario

\author{
in partial fulfillment of the \\ requirements for the degree of \\ Masters of Arts \\ in the program of
}

Photographic Preservation and Collections Management

Toronto, Ontario, Canada, 2013

(C) Sean Fraser Corscadden, 2013 
I hereby declare that I am the sole author of this thesis or dissertation.

I authorize Ryerson University to lend this thesis or dissertation to other institutions or individuals for the purpose of scholarly research.

\section{SEAN CORSCADDEN}

I further authorize Ryerson University to reproduce this thesis or dissertation by photocopying or by other means, in total or in part, at the request of other institutions or individuals for the purpose of scholarly research.

\section{SEAN CORSCADDEN}


The Arnold Newman Collection of Photographs

at the Art Gallery of Ontario

Finding Aid

Masters of Arts 2013

Sean Fraser Corscadden

Photographic Preservation and Collections Management

Ryerson University / George Eastman House

\section{Abstract}

The Arnold Newman Collection of Photographs consists of 4820 photographs taken by photographer Arnold Newman between the years 1938 and 2004. This thesis acts as a research project investigating the collection and making it accessible to researchers and collections management at the Art Gallery of Ontario. The project includes research on the sitting subjects, an overview of the physical photographs, an annotated bibliography and the organization and housing of the collection for permanent accession into the Art Gallery of Ontario's photography collection.

The paper consists of an analytical portion which outlines the methodology of creating the finding aid. The finding aid acts as a standalone paper designed to assist researchers navigating the collection. 


\section{Acknowledgements}

I would like to thank:

Maia-Mari Sutnik, for introducing me to the Arnold Newman Collection of Photographs and for giving me the freedom to make the collection my own.

Robert Burley, for his efforts in refining my thesis.

Arnold Newman, for reminding me to take pictures every day.

Alison Nordstrom, for never holding back.

Thaddeus Holownia, for introducing me to silver.

Laura Stephenson, for your support and encouragement.

Finally, my parents, without whose help I would not have made it this far. 
Table of Contents

THE ARNOLD NEWMAN COLLECTION .........................................................................................................I

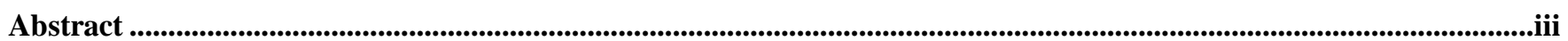

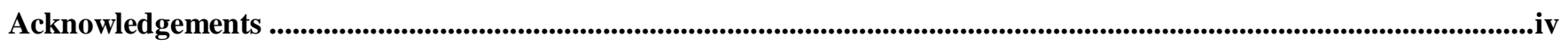

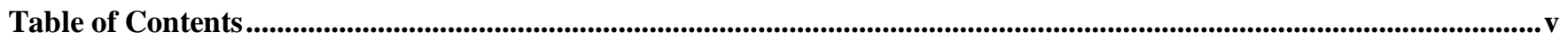

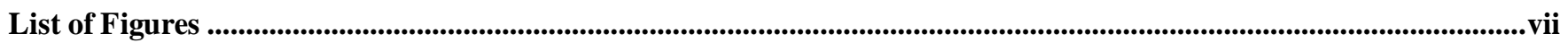

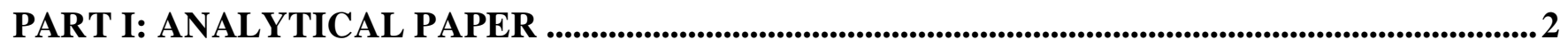

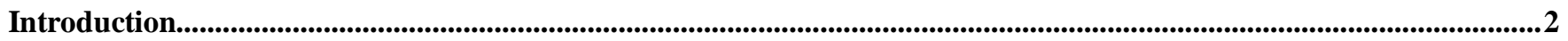

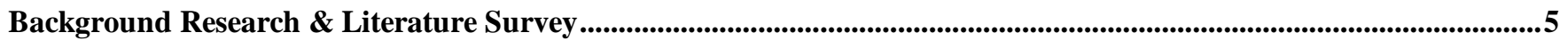

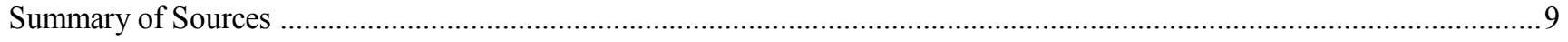

Creating the Finding Aid ...................................................................................................................................................................

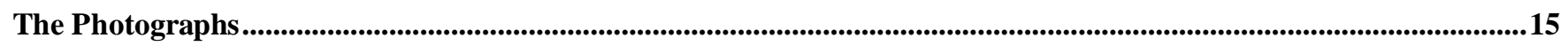

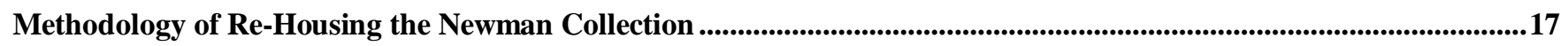

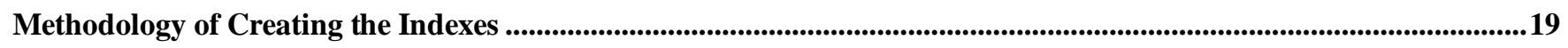

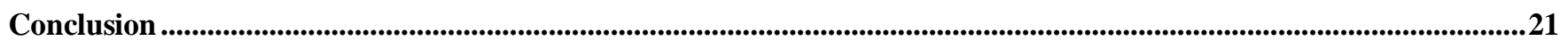

PART II: THE ARNOLD NEWMAN COLLECTIONS OF PHOTOGRAPHS FINDING AID ... 22

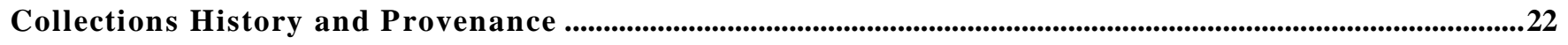

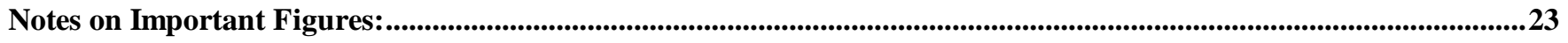

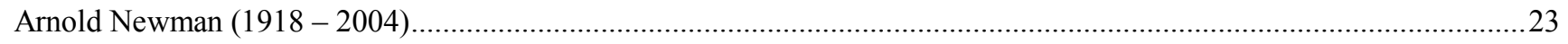

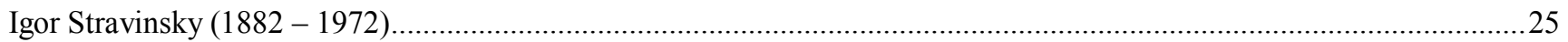

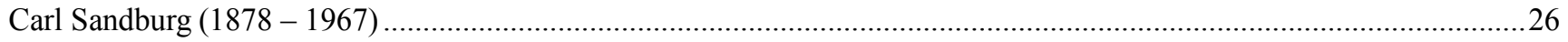

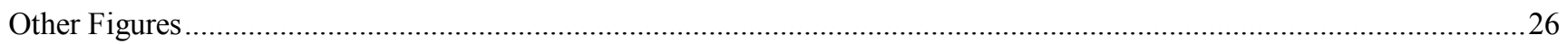

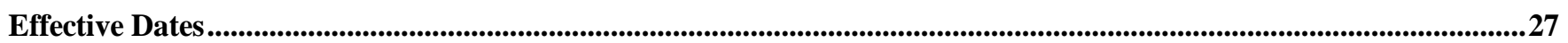

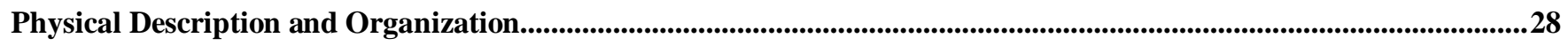

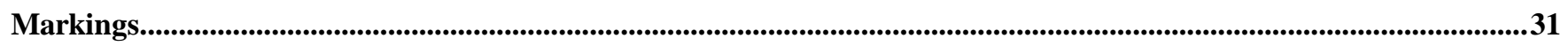

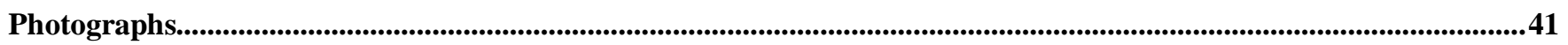

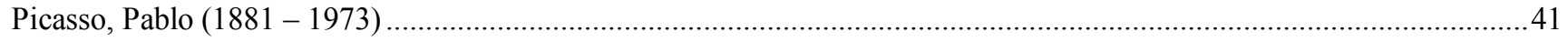


Stravinsky, Igor (1882 - 1971).

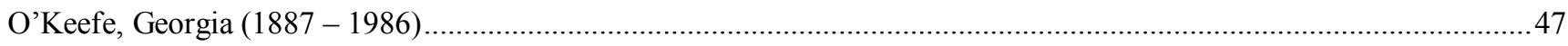

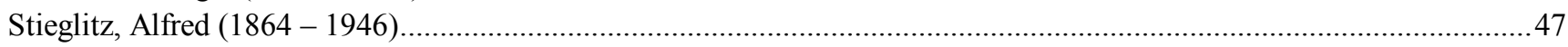

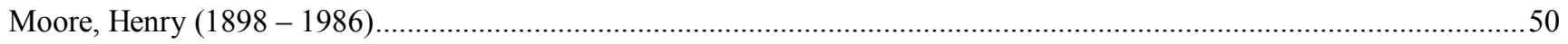

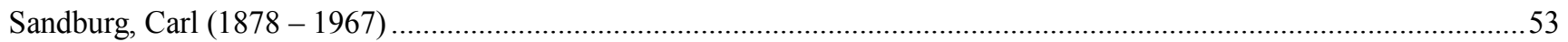

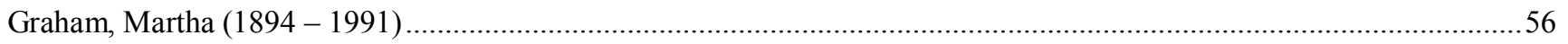

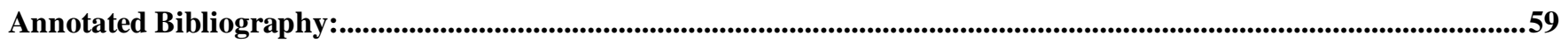

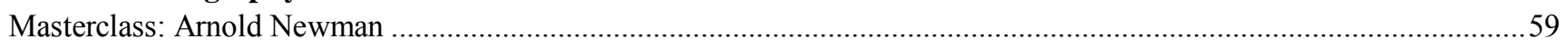

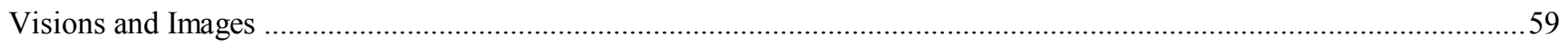

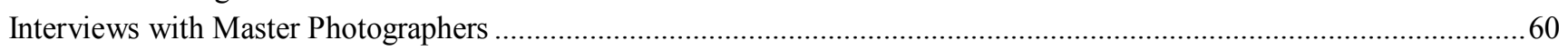

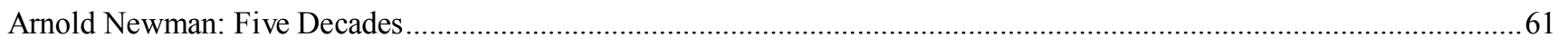

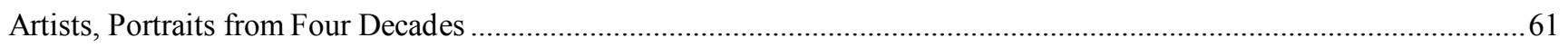

Arnold Newman, Photo District News by Anthony Lasala .....................................................................................62

One Mind's Eye: The Portraits and Other Photographs of Arnold Newman ..............................................................62

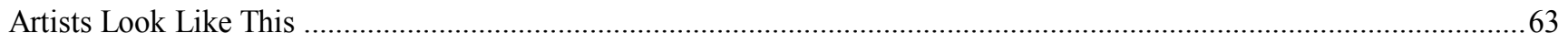

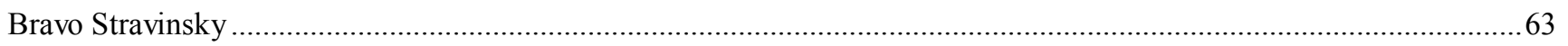

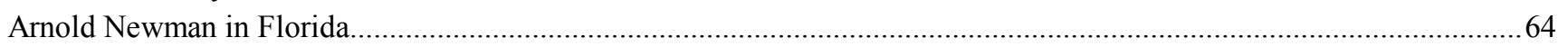

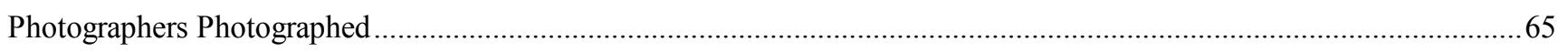

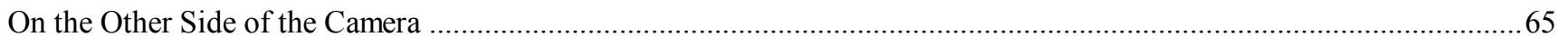

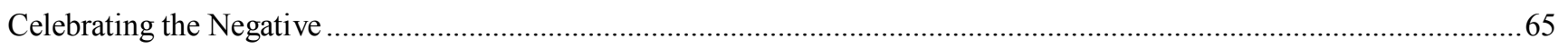

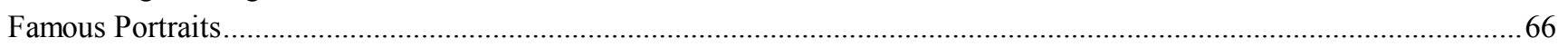

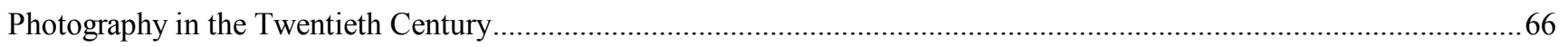

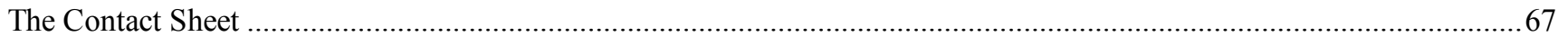

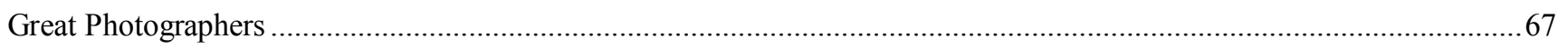

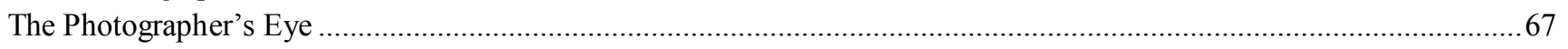

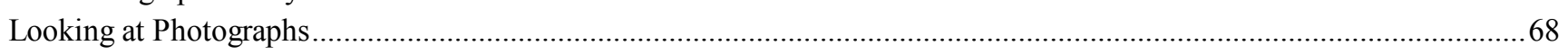

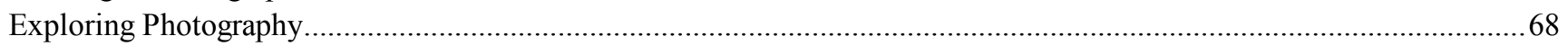

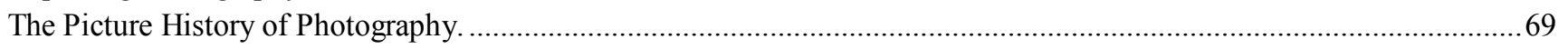

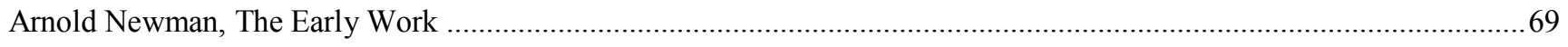

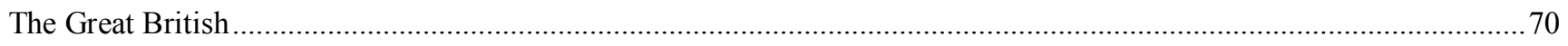

Faces USA.

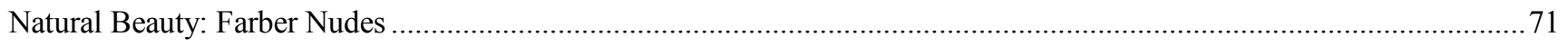

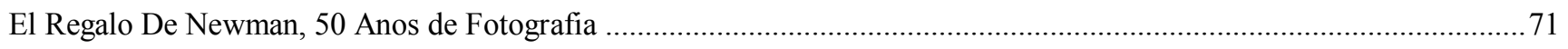

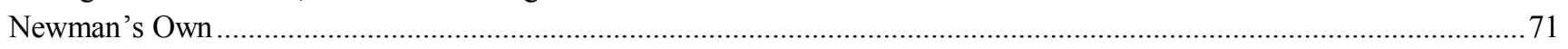

Everyone who was anyone: Arnold Newman photographed the heroes of the 20th century, from Truman to Marilyn

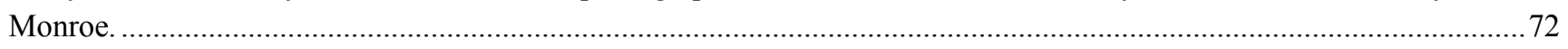

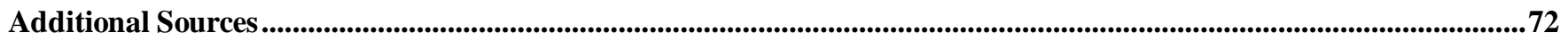

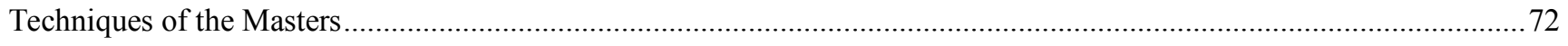

Interview: Photographer Arnold Newman Discusses his Photography and his Book, Arnold Newman ...............................73

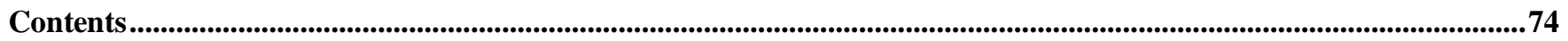

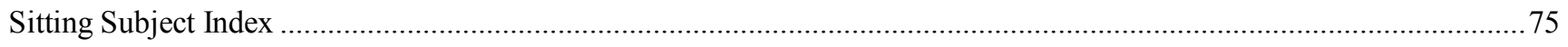

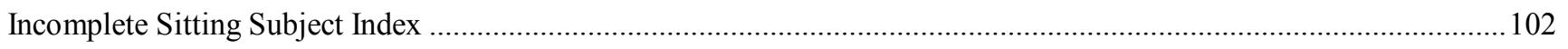

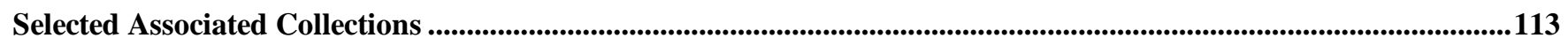

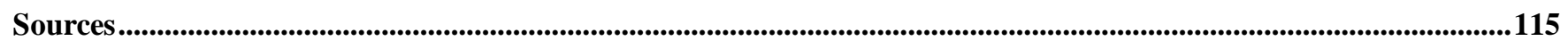




\section{List of Figures}

Figure 1: Recto, AGO.106498 “Arnold Newman - Self Portrait” Print number: 3537 Neg. date: 10/19/1987 ......................23

Figure 2: Verso, AGO.107501 "Pablo Picasso" Print number: 4730 Neg. date: 02/06/1954 ..............................................33

Figure 3: Verso, AGO.107445 “Alexander Calder” Print number: 4674 Neg. date: 20/09/1943 ….....................................33

Figure 4: Verso, AGO.107819 “"Atlantic City” Print number: 5604 Neg. date: 06/04/1947 ...............................................33

Figure 5: Verso, AGO.107291 “I.M. Pei” Print number: 4520 Neg. date: 23/09/1967 …....................................................... 33

Figure 6 :Verso, AGO.104197 “General Dwight D. Eisenhower” Print number: 374 Neg. date: 01/03/1950 ..........................33

Figure 7: Verso, AGO.104483 "Harriman” Print number: 761 Neg. date: 08/09/1954 ……………...................................33

Figure 8: Verso, AGO.103996 “John Hancock” Print number: 129 Neg. date: 10/09/1946 .................................................34

Figure 9: Verso, AGO.104416 "Richard M. Nixon” Print number: 672 Neg. date: 28/09/1953 ..........................................34

Figure 10: Verso, AGO.108067 “Alfred Kinsey” Print number: 5852 Neg. date: 15/05/1948 …........................................34

Figure 11: Verso, AGO.108073 “Jean Picard Ledoux” Print number: 5858 Neg. date: Unknown .......................................34

Figure 12: Verso, AGO.104901 "Milton Avery" Print number: 1345 Neg. date: 06/01/1961 ..............................................35

Figure 13: Verso, AGO.104880 "Edward and Jo Hopper" Print number: 1320 Neg. date: 14/08/1960................................35

Figure 14: Verso, AGO.104739 “Louis Mumford” Print number: 1142 Neg. date: 03/02/1959.........................................35

Figure 15: Verso, AGO.106077 “Arnold Newman - Self Portrait” Print number: 2962 Neg. date: 16/08/1979 .......................35

Figure 16: Verso, AGO.107629 “David Hockney” Print number: 4858 Neg. date: 25/09/1978 ...........................................36

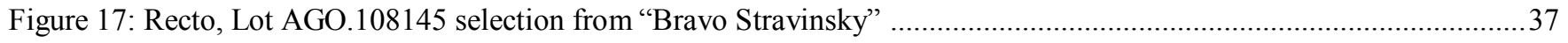

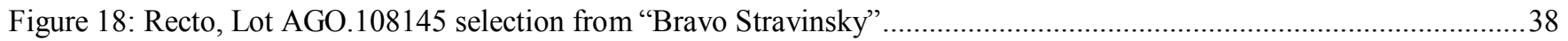

Figure 19: Recto, Lot AGO.108145 selection from "Bravo Stravinsky”. ...........................................................................38

Figure 20: Verso, AGO.107635 "Andrew Lloyd Weber and Tim Rice” Print number: 4864 Neg. date: 13/06/1978...............40

Figure 21: Recto, AGO.107524 "Pablo Picasso" Print number: 4753 Neg. date: 02/06/1954 ............................................42

Figure 22: Recto, AGO.107538 "Pablo Picasso" Print number: 4767 Neg. date: 02/06/1954 ............................................42

Figure 23: Recto, AGO.107518 "Pablo Picasso" Print number: 4747 Neg. date: 02/06/1954 .................................................42

Figure 24: Recto, AGO.107501 "Pablo Picasso" Print number: 4730 Neg. date: 02/06/1954 ...........................................42

Figure 25: Recto, AGO.107505 "Igor Stravinsky” Print number: 4734 Neg. date: 01/12/1946 ….....................................45

Figure 26: Recto, AGO.107511 "Igor Stravinsky” Print number: 4740 Neg. date: 13/12/1966 .........................................45

Figure 27: Recto, AGO.107530 "Igor Stravinsky and Balanchine” Print number: 4759 Neg. date: 08/01/1967 .....................45

Figure 28: Recto, AGO.107544 "Igor Stravinsky” Print number: 4773 Neg. date: 01/12/1946 ..........................................45

Figure 29: Recto, AGO.107492 “Alfred Stieglitz and Georgia O’Keeffe” Print number: 4721 Neg. date: 17/04/1944 ...........48

Figure 30: Recto, AGO.107404 “Georgia O’Keeffe” Print number: 4671 Neg. date: 02/08/1968 .........................................48

Figure 31: Recto, AGO.107493 “Alfred Stieglitz” Print number: 4722 Neg. date: 05/04/1944 ............................................4

Figure 32: Recto, AGO.107405 “Georgia O’Keeffe” Print number: 4670 Neg. date: 02/08/1968 ........................................48

Figure 33: Recto, AGO.106017 "Henry Moore” Print number: 2886 Neg. date: 22/10/1977 ..............................................51

Figure 34: Recto, AGO.106018 "Henry Moore” Print number: 2887 Neg. date: 22/10/1977 ................................................51

Figure 35: Recto, AGO.105260 “Henry Moore” Print number: 1852 Neg. date: 25/06/1966 ….......................................51

Figure 36: Recto, AGO.105261 "Henry Moore” Print number: 1853 Neg. date: 25/06/1966 …........................................51

Figure 37: Recto, AGO.104527 “Carl Sandburg” Print number: 833 Neg. date: 03/11/1955 ….............................................54

Figure 38: Recto, AGO.104528 “Carl Sandburg” Print number: 834 Neg. date: 03/11/1955 ...............................................54

Figure 39: Recto, AGO.104529 “Carl Sandburg” Print number: 835 Neg. date: 03/11/1955 ...............................................54

Figure 40: Recto, AGO.104530 “Carl Sandburg” Print number: 836 Neg. date: 03/11/1955 .............................................54

Figure 41: Recto, AGO.107363 “Martha Graham” Print number: 4592 Neg. date: 02/03/1961 ...........................................57

Figure 42: Recto, AGO.107412 “Martha Graham” Print number: 4683 Neg. date: 02/03/1961 ........................................57

Figure 43: Recto, AGO.107411 "Martha Graham” Print number: 4712 Neg. date: 02/03/1961 ….....................................57

Figure 44: Recto, AGO.107413 “Martha Graham” Print number: 47639 Neg. date: 02/03/1961 .......................................57 


\section{Part I: Analytical Paper}

\section{Introduction}

While there are many different types of finding aids that have been created by various institutions, each has tailored these aids to suit their individual collections and mandates. For the purposes of this thesis project, a finding aid will be defined as "a descriptive document created to allow retrieval. Types of finding aids include file lists, inventories and guides." ${ }^{11}$ As such, this paper's goal is to outline an investigation into the series of decisions made during the development of the Arnold Newman Collection of Photographs Finding Aid at the Art Gallery of Ontario. In doing so I plan to establish, expand upon and clarify the decisions I made throughout the development of this project.

The Newman Collection was acquired by the Art Gallery of Ontario, in Toronto, Canada, in the summer of 2012. Donated anonymously, the collection contained 4820 of Arnold Newman's photographs created between 1938 and 2004. The collection was composed of a main body of work which included portraits, a Bravo Stravinsky book dummy, photographs for a book on Carl Sandburg which never came to fruition, a group of prints documenting Newman's exhibitions and a group of photographs which are inscribed by the documented sitting subjects. ${ }^{2}$ The Newman Collection represents a large-scale body of work produced by a seminal American portrait photographer who captured historically prominent figures from the $20^{\text {th }}$ century. Therefore, this is an important collection for the Art Gallery of Ontario and was the basis of my graduate research project.

I was introduced to the collection in the summer of 2012 by Art Gallery of Ontario curator Maia Sutnik during the course of an internship where I completed a preliminary catalogue of the majority of

\footnotetext{
${ }^{1}$ The University of Toronto Library system defines finding aids in this manner. Many other academic institutions, including Ryerson University use similar vocabulary. "Glossary." UofT Archives \& Records Management Services. Web. 30 June 2013. <http://www.library.utoronto.ca/utarms/info/glossary.html>.

${ }^{2}$ Due to confidentiality agreements, further information may not be provided regarding the collection's history, the collector, the interactions between the collector and the Art Gallery of Ontario or the collection's monetary value.
} 
the photographic objects in the Newman Collection. During this time it became apparent that the collection would benefit from additional research and more thorough organization. I proposed that I continue working on the collection by creating a finding aid, making the collection more accessible by providing research on Newman and the portrait subjects found within the collection.

The collection arrived in disarray, housed in a variety of boxes with the majority of the prints stacked in banker's boxes. The Newman Collection is interesting when compared to other archival collections of comparable sizes in that it does not contain much diversity in terms of materials and/or the sizes of the photographs. The collection is entirely composed of photographic objects, which are largely black and white gelatin silver prints on "standard" sized paper. ${ }^{3}$ These are work, reference and exhibitions prints. There are no negatives or handwritten letters, and there are no drawings or technological objects. The furthest deviation from this standard is a book dummy, which is largely composed of silver gelatin black and white photographs with an accompanying draft of written content. As a result, dividing the collection by material or providing brief descriptions of the material objects would not effectively assist a researcher approaching the collection for the first time due to the fact that this information becomes increasingly redundant. ${ }^{4}$ The homogeneity of this collection ultimately affected how this finding aid was constructed.

The remainder of this essay will elaborate on the research conducted and the steps I took in creating the Newman Collection Finding Aid. To begin the construction of this finding aid, one needs to imagine how the collection would be used in the future. How would a researcher interact with this material? Considering Newman's history as an internationally renowned portrait photographer, it is safe

\footnotetext{
${ }^{3}$ Standard sized photographic paper tend to be $5^{\prime \prime} \times 7 ", 8$ " X 10", 11" X $14^{\prime \prime}, 16^{\prime \prime} \times 20^{\prime \prime}$ and $20^{\prime \prime} \times 24$ ".

${ }^{4}$ For example, if a researcher was to use a TMS excel spreadsheet to organize the information by media type, approximately 12 entries would show up as chromogenic prints, followed by over 4,700 entries labelled as silver gelatin prints that are either mounted or un-mounted.
} 
to assume that just as many, if not more, researchers would be interested in the subjects of the images as they would be interested in the photographs themselves as expressive objects. In fact, researchers are more likely to be using the collection as a resource for photographs of influential $20^{\text {th }}$ century personalities. This being said, this paper will also cover the photographic objects, what problems were encountered regarding organization and time constraints. Further, this finding aid may be of service to those who wish to navigate the collection without having to search through the thousands of associated records within The Museum System (TMS) database; the current collections information system of the Art Gallery of Ontario. The paper will end by detailing currently unresolved issues that may be explored by future managers of the Newman Collection. 


\section{Background Research \& Literature Survey}

As stated in my introduction, there are very few sources on best practice when constructing a finding aid. This may be attributed to the wide variety of institutions and mandates governing the innumerable collections that exist in the international archival and collections world. The guides that do exist tend to be either too vague for the purposes of this project, or defined for a collection that includes a broader range of archival materials. It might also be suggested that standards for finding aids are difficult to determine because institutions often customise these tools to suit their specific collections and practices.

In conducting a literature review on the subject of creating finding aids, I searched through online collections of finding aids, most notably the Library of Congress and other finding aids constructed by international collections managers and theses written by past students of the Ryerson Photographic Preservation and Collections Management program at both the Art Gallery of Ontario and George Eastman House. Considering the range of finding aid construction guides created by different institutions, this literature survey will not attempt to cover all of these sources, but instead give some examples that have affected the decisions made in completing this project.

The Library of Congress has a significant collection of finding aids, all of which follow electronic archival description (EAD) methodologies. ${ }^{5}$ These sets of standards were helpful in constructing this finding aid, in that it highlighted a number of elements that should be included, such as scope and content, effective dates, biographical sketches, and arrangement. This being said, the methodology is designed to create a standardized format of finding aid creation for the institution, as

\footnotetext{
${ }^{5}$ Library of Congress has an online website dedicated to explaining the standards that make up the Electronic Archival Description program, including the XML schema it outlines. This can be found at: "EAD Best Practices." Library of Congress Finding Aids. Library of Congress, Web. 30 June 2013. <http://www.loc.gov/rr/ead/lcp/>.
} 
there are numerous searchable finding aids online. There are certain code properties that have been established to ensure content can easily be transferred online. Furthermore, the database appears to have been developed to suit the purposes of creating a general collection summary as opposed to an object by object finding aid. This is understandable considering that the collection of objects within the Library of Congress varies significantly by type.

An additional source for finding aid construction that was useful in creating the Arnold Newman Collection Finding Aid was the construction guidelines used by the Benson Ford Research Centre. ${ }^{6}$ While the collections held at this institution are historical in nature, the construction guidelines outline an effective way to organize the content in a finding aid. However, much of the information is not applicable to this project, as they use very different cataloguing procedures for documenting their objects. The Historical Society of Western Pennsylvania created a finding aid that is very similar to the ones described above, ${ }^{7}$ and this construction guide also influenced some minor aspects of my finding aid.

Lisa C. Henessey, a former student of the PPCM program, assembled a thorough finding aid for a collection of photographs held at George Eastman House in Rochester, New York. ${ }^{8}$ Using her finding aid as a basic model, I decided to include additional areas of research into the finding aid I otherwise would not have. For example, Hennessey's choice to include an independent analytical paper outlining the creation of the finding aid directly inspired the format of my research project. However, there are categorical differences between our two collections that prevented me from using her model as a

\footnotetext{
${ }^{6}$ Stuchell, Lance. Creating Finding Aids at the Benson Ford Research Center. Benson Ford Research Centre 1.1. Michigan: 2012

${ }^{7}$ University of Wisconcin. Style Manual for Archival Finding Aids for the University of Wisconsin Digital Collections Center. University of Winsoncin: 2002.

${ }^{8}$ Hennessey, Lisa C. The Mark A. Freeman Collection of World War II Photographs At George Eastman House. Diss. Ryerson University, 2007. Toronto, Ontario: Ryerson University, 2007.
} 
complete foundation. Hennessey was working with a smaller number of photographs, allowing her to go into greater detail with her cataloguing. Further, the photographs Hennessey studied have a unifying subject matter, World War II, which provided her with different research opportunities. Hennessey was able to undertake research on the singular subject matter alongside the creation of detailed catalogue entries. Working with approximately five times the number of photographs in the Newman Collection precluded detailed catalogue entries. Further, the range of subjects and unfamiliarity with the subject matter of each individual print limited my research to identification and index creation-the essential tasks of my project.

Finally, the last source of information that affected the development of the Arnold Newman Collection Finding Aid was Arnold Newman's Sitting Book. ${ }^{9}$ Using simple tables, the artist wrote down basic information regarding certain sitters, such as when he took specific photographs and the names of his clients. Creating a complimentary finding aid with the sitting book would increase the finding aid's interoperability with collections of Newman's work at other institutions.

The finding aid includes an annotated bibliography which helped inform the finding aid's shape and construction. Newman's numerous photographic publications have many organizational qualities that remain consistent throughout the various books. A sitting subject index is almost always included; this is especially true of those publications which focus on Newman's photographs exclusively. Including a similar index would assist researchers in finding particular prints that may be found within the Newman Collection. Some of the more prominent publications that scholars should investigate when researching Newman include: Arnold Newman: Five Decades, One Mind's Eye: The Portraits and Other Photographs of Arnold Newman, Bravo Stravinsky, Arnold Newman in Florida, Interviews with

\footnotetext{
${ }^{9}$ Newman, Arnold. The Arnold Newman Sitting Book. Arnold Newman Archives, Web. June 302012. <http://www.arnoldnewmanarchive.com/index.php?option=com_content\&view=article\&id=151\&ltemid=33>.
} 
Master Photographers and the Eastman Kodak video publication Techniques of the Masters. All of these sources have been expanded upon in the annotated bibliography section of the finding aid.

There are a wide variety of subjects and publications that inspired the format of this finding aid. Based on the information and literature that would be applicable to the construction of the Newman Finding Aid, I selected individual elements that would be useful in navigating the Newman Collection of 4820 photographs. These elements include biographies on important figures, an overview of the various markings that can be found on the Newman photographs, an overview of some of Newman's portraits, an index containing approximately 1,300 captured subjects and an annotated bibliography covering Newman's published works and interviews. 


\section{Summary of Sources}

"EAD Best Practices." Library of Congress Finding Aids.Library of Congress, Web. 30 June 2013.

$<$ http://www.loc.gov/rr/ead/lcp/>

"Glossary." U ofT Archives \& Records Management Services. Web. 30 June 2013.

<http://www.library.utoronto.ca/utarms/info/glossary.html>

"Style Manual for Archival Finding Aids for the University of Wisconsin Digital Collections Center." University of Winsoncin (2002): Print.

Cox, Richard. "Revisiting the Archival Finding Aid." Journal of Archival Organization 5.4 (2008): 5-32. Print.

Gallery Systems. Web. 30 June 2013. <http://www.gallerysystems.com/contact>.

Danziger, James, and Barnaby Conrad. Interviews with Master Photographers. New York: Paddington, 1977.

Eastman Kodak Corporation "Techniques of the Masters.Arnold Newman and Andreas Heumann." Kodak Business

Television. KBTV. Rochester, New York, 1990.

Hennessey, Lisa C. The Mark A. Freeman Collection of World War II Photographs At George Eastman House. Diss. Ryerson University, 2007. Toronto, Ontario: Ryerson University, 2007. Print.

Newman, Arnold. The Arnold Newman Sitting Book. Arnold Newman Archives, Web. 30 June 2013.

<http://www.arnoldnewmanarchive.com/index.php?option=com_content\&view=article\&id=151\&ltemid=33>

Newman, Arnold, Richard A. Madigan and Bruce Weber. Arnold Newman in Florida. Boston, MA: D.R. Godine in Association with Norton Gallery of Art, 1988.

Newman, Arnold, Robert Craft, Francis Steegmuller, and Igor Stravinsky. Bravo Stravinsky. Cleveland: World Pub., 1967.

Newman, Arnold, and Robert Sobieszek. One Mind's Eye: The Portraits and Other Photographs of Arnold Newman. Boston: D. R. Godine, 1974.

Ollman, Arthur, and Arnold Newman. Arnold Newman: Five Decades. San Diego: Harcourt Brace Jovanovich Publ., 1986.

Stuchell, Lance. Creating Finding Aids at the Benson Ford Research Center. Benson Ford Research Centre 1.1. Michigan: 2012 


\section{Creating the Finding Aid}

At the inception of this project I approached the Art Gallery of Ontario's curator Maia Sutnik and the gallery's collection management staff and proposed the creation of a finding aid for the Newman Collection. I felt this was an ideal Master's thesis project as I spent the summer of 2012 cataloguing the photographs contained within the collection. Achieving this goal would require a substantial amount of research on finding aid construction, investigating associated catalogue records and the sitting subjects within the collection, in addition to research on Newman himself. My initial research on Newman was broad, based on his photographic career and his iconic portrait sessions. Including the large publications on Newman alongside smaller interviews within the annotated bibliography would help give researchers context to his published material.

To begin, many finding aid construction guides and archival researchers note the increasing number of systems and databases being used by archival institutions. ${ }^{10}$ The catalogue of accession entries is perhaps the most well known and most used system of abstracting object information into a searchable database. As such, understanding the cataloguing program used by the Art Gallery of Ontario and how it functions within the institution are factors that were fundamental to the construction of this finding aid.

The Art Gallery of Ontario uses TMS as their cataloguing program of choice, which operates according to a series of tables that allow for input of information in any number of formats. These individual records can be printed off and viewed, or a large number can be consolidated into excel spreadsheets. However, these tables present researchers with a large amount of data that could be difficult to navigate. Having had to sort through and interpret similar spreadsheets in the creation of this finding aid, I became familiar with this complex system throughout the development of this project.

\footnotetext{
${ }^{10}$ Cox, Richard. "Revisiting the Archival Finding Aid." Journal of Archival Organization 5.4 (2008): 5-32. Print.
} 
TMS is not a user-friendly search engine, as it requires accurate description for record retrieval. ${ }^{11}$ The program is constantly being revised, requiring continuing education for collections managers. If an untrained researcher were allowed to freely navigate this program they would most likely have trouble finding the information or the photograph they needed. What is even more troublesome is that they might accidentally destroy important information in the catalogue. Finally, TMS is a proprietary program relying on the continued existence of its developing company. ${ }^{12}$ Creating an effective research alternative not only increases efficiency for researchers, but will also provide a searchable alternative for those unfamiliar with the TMS database system. Knowing this, my finding aid is to be accessible for navigation and a reliable source of information and as such it will need to be organized in a different way from the Art Gallery of Ontario’s TMS database.

I did not want the Newman Finding Aid to be completely independent from TMS; if the program were ever to become obsolete, a finding aid would be the only alternative to accessing the collection. Saying this, I readily acknowledge that the chances of TMS crashing or losing all the information contained within are quite minimal. Interoperability with information from TMS will improve the finding aid and will ensure that the aid provides a reliable alternative for the future. If this is to be achieved, the finding aid must have complete coverage of the collection in one form or another. To do this, I have broken down the collection by subject (sitter, place, subject matter) and have then listed the location, negative date and number of photographs for each sitter. By doing this alphabetically, one can easily navigate the collection and find the required information in an effective and intuitive manner. This

\footnotetext{
${ }^{11}$ Searching for particular prints in TMS requires that one is aware of particular print qualities beforehand. For the Newman prints, this can be problematic when you consider the physical homogeneity of the collection. Knowing that there is an 8 "X10" print of an American politician in the collection will do little good during a search unless you know additional specific details.

12 The Museum System is a product produced by Gallery Systems, a company based out of New York City, New York, The United States of America. "Contact Us." Gallery Systems.Web. 30 June 2013. <http://www.gallerysystems.com/contact>.
} 
decision was also influenced by publications containing Arnold Newman photographs which often include a similar index. ${ }^{13}$

Covering the collection and creating a finding aid has a greater impact than simply providing researchers with a navigation tool. There will likely be a wide variety of researchers accessing this finding aid with differing intentions, and therefore there needs to be a variety of approaches in establishing coverage of the collection. As such, the finding aid was designed using a top-down approach to ensure the success of interested researchers. This has been achieved by providing an overview of the entire collection, ${ }^{14}$ each sub-collection and each box. ${ }^{15}$ Furthermore, by using a largescale index, I have provided an overview of the portrait subjects that can be found, down to the number of associated objects. ${ }^{16}$ In accordance with best practices at the AGO, a box summary has been included with each box that gives a breakdown of the objects contained within. The Newman Collection will be accompanied by a compact disc that will include excel spreadsheets of all box summaries alongside digital file formats of the finding aid.

Creating a finding aid that can be easily edited or changed by collections managers and skilled users is a very important aspect of this project. As there are no pre-written guidelines created by the Art Gallery of Ontario in establishing a finding aid for a project of this size, I took initiative in working with already established aspects of their cataloguing system. By doing so I have created a finding aid that could be used to further benefit cataloguers who wish to work on the collection in the future, as it is evident that there will be additional work that can be pursued with this collection in TMS. I have also used basic programs such as Microsoft Word and Microsoft Excel to ensure that future users can edit the

\footnotetext{
${ }^{13}$ See the Annotated Bibliography section of the Finding Aid. Publications which contain these sitting subject lists have a note at the end of the annotation.

${ }^{14}$ See Scope and Content in the finding aid.

${ }^{15}$ See Physical Description and Organization in the finding.

${ }^{16}$ See Subject Index in the finding.
} 
finding aid to better suit their needs. For example, the TMS catalogue records for the Arnold Newman Collection of Photographs contain all of the titles of the sitting subjects; however, records for these approximately 1300 constituents have not yet been created. By using my finding aid, cataloguers can create basic constituent records for the sitting subjects without having to do additional research to identify the sitter.

Changing technology within archival institutions is inevitable, as is technological obsolescence. Communicating simple information as efficiently as possible would ensure that the information could be edited and adapted in the future. This is especially true for the index I have designed. I accomplished this by breaking up my finding aid into a number of highly compatible file formats and have kept all of this information within the collection itself in archival CD format and a USB thumb drive, alongside a printed hard copy. ${ }^{17}$ The included instructions on how to edit and use this information will assist future users in editing and modifying the finding aid to suit their own needs.

Finally, one of the more important aspects of creating a finding aid is the amount of time an institution can dedicate to its creation. For many institutions, dedicating the time necessary to create an object-by-object finding aid is not possible. This is especially true when dealing with approximately 5000 objects. In many situations, a catalogue record can act as an alternative to the finding aid for those who regularly access the collection. As discussed earlier, this is not an effective solution for encouraging researchers to investigate the collection, and does not translate well to those unfamiliar with TMS vocabulary.

\footnotetext{
${ }^{17}$ The CD-Rom that accompanies this finding aid will have all the source material in their primary formats (.doc and .xlxs) and will also be in an open source format. (.pdf) This has been done to help future proof the digital copies from becoming obsolete.
} 
An additional source of information that I felt was necessary to include was an annotated bibliography. Newman was a significant post-war American photographer who was widely collected and exhibited by major fine art museums. As such, he had to opportunity to publish a number of monographs of his work and he was included in many anthologies about photography and portraiture. Annotating the major publications associated with Arnold Newman and including an overview of his interviews will inform researchers of the many publications associated with Arnold Newman and his photographs.

One of the goals of this project, was to dedicate a significant amount of time to creating a finding aid, while diverting minimal resources from the AGO. This is one of the major reasons I felt creating a finding aid would be a useful and necessary project, as it could be largely completed offsite with minimal supervision. This being said, there are a number of steps that will need to be taken in the future to ensure the preservation of this collection. Due to the size of the collection and limited resources, there were some preservation and collections management practices that could not be fulfilled. These steps include applying accession numbers to the prints, fully expanding each catalogue entry, expanding the lots for the Carl Sandburg, Bravo Stravinsky and Exhibition Prints, and ensuring each object has been housed in archival mylar sleeves. I have expanded upon and provided possible solutions to these shortcomings in the conclusion section of the finding aid. 


\section{The Photographs}

The photographs in the Newman Collection are fairly uniform in terms of their physical characteristics. There are a small number of chromogenic colour prints; however, the majority of the prints are black and white silver gelatin, both toned and un-toned, and can be found loose, mounted on board, masonite or matted. The prints are generally found in good condition, a few are yellowing with age and some have visible fingerprints. However, researchers will more than likely be investigating this collection for the content of the photographs rather than the physical characteristics of the prints. This being said, another area for potential interest and research beyond the subjective interpretation of the photographs are the markings located on both the recto and verso of the photographs.

These marks and inscriptions have all been successfully documented and transferred into the TMS database; however, this information is abstract and without any context may be difficult to understand. A section in the finding aid has been dedicated to briefly analyzing a number of different photographs which display these markings. I have included brief descriptions of the markings, which photographs are being shown and where they may be found. While writing this section it became clear to me that explanations of the markings alone would not be sufficient. Vocabulary that is deeply rooted in photographic practice must be used on a regular basis and in light of this I have provided some basic definitions to assist researchers who may not be aware of the full range of photographic techniques and terms. Burning, dodging, recto and verso are some of the basic terms that have been defined. A large selection of artist stamps used by Newman throughout his career has been incorporated alongside the different styles of signatures. Print number and sitting book numbers have been explained, and some information on image surface marks has been provided. 
Although many of Newman's photographs are well recognized and considered to be iconic images, including a selection of five to six studio sessions will inform researchers who may not be aware of Newman's photographic legacy. Brief descriptions underneath the images will provide context. By showing photographs that are represented in the collection alongside a number of variants, researchers will get an idea of Newman's photographic approach without actually having to access the collection. It is important to include the markings and photographs sections because all of the publications I have investigated in the annotated bibliography fail to thoroughly investigate the markings or the myriad of variants that exist for particular images. Including this information may satisfy a researcher enough that they will not need to inspect the Newman collection physically. 


\section{Methodology of Re-Housing the Newman Collection}

In the summer of 2012, I had the opportunity to work with the Newman collection over a twelveweek internship. During this time I learned the role of collections management at the AGO. I was asked to complete a basic catalogue ${ }^{18}$ of the photographs and work on these objects over the course of my placement, during which time I catalogued the vast majority of the collection. Knowing that there was simply far too much material for a single student to deal with in 12 weeks, I proposed to continue working on the collection for my thesis project, with the plan to eventually create a finding aid.

In order for this to be a useful finding aid, a reorganization of the collection had to occur. This was made evident to the curator and collections management during the acquisition process. The photographs had been stored in a variety of boxes, including banker's boxes. The original owner inscribed print numbers in ascending order onto these photographs; however, this arrangement has yet to be identified as having any organizational advantages. This problem lead to the decision that a total reorganization of the collection would be required, which was determined by a group that included the curator, the collections managers and myself. My responsibilities included an initial assessment of the collection as well as the creation of a more effective physical and intellectual arrangement through cataloguing the objects. I proposed a more thorough project, thereby improving the functionality of the collection, as my thesis.

This was completed by printing out a list of each subject's name that was reformatted into a last name, first name table which was then alphabetized. The list was then matched to the 4820 photographs assembled for inspection and the prints were slowly and carefully reorganized based upon the box number assigned to each photograph. Particular prints were removed based on their subject matter (i.e.

\footnotetext{
${ }^{18}$ These TMS records includes Title, Date, Markings, Inscriptions, Size and Medium data entries.
} 
abstractions) and then each box was given a certain number of prints dependent upon how many were mounted and how many were un-mounted. ${ }^{19}$ This was not done for the sub lots for Bravo Stravinsky, Carl Sandburg, the Arnold Newman Exhibition Prints or the inscribed photographs, as these are to be catalogued individually at a later date.

Each box contains approximately 45-65 prints, depending on space requirements, and each box has been arranged in a pyramid scheme, meaning that the largest photographs are at the bottom, with subsequently smaller photographs stacked on top. Considering that the majority of photographs in the collection are standard sizes, this means that most boxes are organized 8 "x10" on top of 11 "x14" on top of 16 "x20" photographs. ${ }^{20}$ Each size has been organized alphabetically from top to bottom. There are one to two boxes for oversized prints. The box indexes located in each box have been organized in this way and contain basic information located in TMS alongside them. The individual Newman prints have been assigned Art Gallery of Ontario Identification (AGO ID) numbers for primary tracking and accountability for registration inventory, and have placement holders assigned for accession numbers to be subsequently tagged and labeled onto the prints. While incompletely accessioned at the time of developing the organizational structure for the collection, each index row will link the AGO ID number to the corresponding print number, which is written in pencil in the bottom left hand corner of each photograph. This will easily allow future work on the collection to address these issues.

\footnotetext{
${ }^{19}$ A mounted print could take up to 5 times the amount of space an un-mounted photograph would.

${ }^{20}$ This style of organization for objects of multiple sizes is considered best practice by many photographic institutions, including the Art Gallery of Ontario and George Eastman House.
} 


\section{Methodology of Creating the Indexes}

Going into this project, I was of the opinion that the success of the finding aid would hinge on the quality of the indexes. Ensuring complete coverage of the collection meant I would have to determine the final arrangement of the indexes beforehand, as going back to add any additional information would take many hours. Choosing what information to include was determined through investigating a number of sources. As I mentioned earlier in this paper, I wanted the finding aid to work with TMS, but still remain completely independent. To do this, I examined TMS to see what information could not be included, or had yet to be included in the records. The largest area that is missing from the TMS records is constituent entries for the sitting subjects. Including brief information on each sitting subject would assist researchers in identification and also act as a source for when collections management decide to attach constituent records for each object in the future.

There was a list containing hundreds of sitting subjects that was provided with the collection upon acquisition. Knowing that Arnold Newman generally took photographs of well-known public figures made identifying these subjects fairly straightforward. This being said, there were a number of subjects that I was unable to identify due to a number of reasons, including Newman misspelling names, the previous collector providing the AGO with incorrect data, or lacking sufficient information to successfully identify the sitter. I decided to include nationality and life dates, because these are basic records in TMS for constituents. I also decided to include occupation; this decision was informed by Newman's sitting book, which would intermittently include this information next to a subject's name. ${ }^{21}$

Most of the identification process was completed by researching a variety of sources, including but not limited to encyclopaedia articles, library of congress records, death certificates, newspaper

\footnotetext{
${ }^{21}$ Newman, Arnold. The Arnold Newman Sitting Book. Arnold Newman Archives, Web. 30 June 2013. <http://www.arnoldnewmanarchive.com/index.php?option=com_content\&view=article\&id=151\&ltemid=33>.
} 
articles, obituaries, artist websites, gallery websites, and so on. Any sitting subject name that brought up multiple identities was noted for visual identification at a later date. If no pertinent information could be obtained then the subject was marked as unidentified. Many subjects marked as unidentified are based upon the format of the name provided. i.e. Dr. Smith could be any number of Dr. Smith's, and considering the large number of incomplete names (almost 300), attempting to visually identify each one at this time in the project would be an inefficient use of available time. 


\section{Conclusion}

This finding aid has been constructed through my personal experiences while familiarizing myself with this extensive collection. When the Arnold Newman Collection of Photographs arrived at the AGO it was disorganized, poorly housed, not catalogued and difficult to navigate. At the beginning of this project I had one primary goal, which was to make the collection accessible. I have hoped to achieve this through a thorough, albeit basic, catalogue of each object, a thorough reorganization, an object by object inventory with basic research completed on every subject alongside an overarching investigation into Arnold Newman, publications on his work, and some major projects that are found within this collection.

There are still a number of tasks that need to be completed within the collection. For future users and managers of the collection, each object should be more thoroughly catalogued. By using the sitting subject index as a reference tool, collections management can easily apply relevant constituent information to each photograph. By using the box lists included with the physical photographs one can easily apply accession numbers onto the photographs. Finally, the basic cataloguing information will help inform future preservation projects, such as housing each object in an archival mylar sleeve. 


\section{Part II: The Arnold Newman Collections of Photographs Finding Aid Collections History and Provenance}

The Arnold Newman Collection of Photographs was donated by a single anonymous donor in the fall of 2012. The core collection was managed by Ron Kurtz on behalf of the estate of the artist. The collection has been appraised for fair market value by two independent and accredited appraisers. Information regarding the donation of the collection and the appraisal process is currently confidential. When and if this information becomes publically available it will be added to the finding aid. As such, this information may not be included in the Arnold Newman Finding Aid. At the time of the creation of this finding aid, the vast majority of the collection has been accounted for with basic catalogue data. Copyright of the images in the Arnold Newman Collection of Photographs resides with the Arnold Newman Estate. The Art Gallery of Ontario has license to reproduce these images for all purposes related to the collection and its use at the Art Gallery of Ontario. 


\section{Notes on Important Figures:}

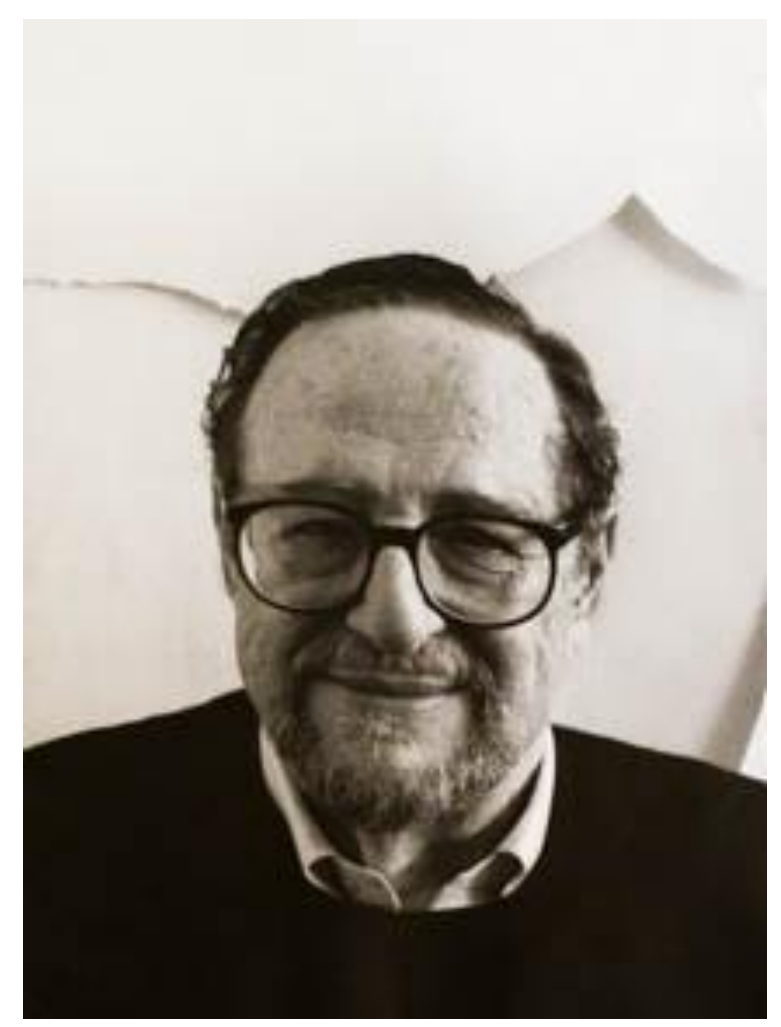

Figure 1

Arnold Newman (1918 - 2004)

Arnold Newman was an American photographer with a career spanning over 60 years. His signature style, described as "environmental portraiture," defined his photographic practice. Arnold was born in 1918 to Freda and Isador Newman in the Manhattan district of New York City. The family lived there briefly before relocating to Atlantic City and eventually settling in Miami, Florida. In 1936 at the age of 18, Newman enrolled at the University of Miami where, for the first time, he began to seriously study art; initially drawn to sculpture, painting and drawing. In Newman's second year of university he ran out of funds to continue studying and applied for work at a photographic studio owned by Leon A. Perskie in Philadelphia, where he made 49 cent portraits. While working in Philadelphia, portraiture not 
only became Newman's primary income, but emerged as his primary source of creative and artistic expression.

In 1939 Newman received a job offer for a management position at a photographic studio in West Palm Beach, Florida. This move marked the beginning of Newman's career as a nationally recognized portrait photographer and his reputation grew with a number of commissions by prominent clients eager to have him capture their likeness. Many of the photographs he took during his time in West Palm Beach are represented by the Arnold Newman Collection of Photographs. Several of the prints are labelled as being taken in West Palm Beach; however, there is the possibility that many other photographs went unlabeled by Newman and as such may appear throughout the collection.

In the mid-1940s Newman invested in a large format press camera, and was offered a joint exhibition with Ben Rose at the A-D Gallery in 1941. Over the next two years he built up a portfolio of portraits and expanded his photographic skillset while living in New York City. In 1942 he moved back to West Palm Beach and opened up a commercially successful portrait studio.

In 1946 Newman returned to New York City and began working for many large publications, including Newsweek, Life Magazine and Fortune Magazine. He defined himself through portraits of international public figures from a wide range of professions. His signature style, "environmental portraiture," captured subjects in their day-to-day lives. Some of the more famous examples from this period can be found in the Examples of Photographs section of the finding aid.

Newman's career continued to skyrocket through the 1950's to the 1970's. He photographed five American Presidents, hundreds of artists, politicians, musicians and royalty from around the world. His portraits represent a significant record of faces from the $20^{\text {th }}$ century. He passed away in New York City in 2004, leaving behind his wife and two sons. 
While Newman is best known for his portraits of well-known public figures and celebrities, the Newman Collection also contains a number of self-portraits taken throughout his life. After closing his studio, Newman continued to take photographs for pleasure, recording personal events and gatherings with friends and family. A selection of examples from the Newman Collection can be found in the Photographs section of the finding aid.

\section{Igor Stravinsky (1882 - 1972)}

The Newman Collection contains many photographs of Igor Stravinsky, including a book dummy entitled "Bravo Stravinsky." The box containing this book dummy can be found within the Physical Organization section of the finding aid. Arnold Newman owes much of his professional success to a photograph of Igor Stravinsky, which gained much critical acclaim. This photograph, including variants, can be found in the Photographs section of the finding aid. Additional photographs can be found in the sitting subject index.

Igor Stravinsky was a Russian born composer who gained notoriety through his three compositions, The Firebird, Petrushka and The Rite of Spring, which were performed in Paris between 1910 and 1913. At the outbreak of World War I, Stravinsky lived in Switzerland, continuing to write and compose. However, with the numerous social and political issues associated with World War I, he had a difficult time collecting royalties on his compositions and theatrical works, especially on plays performed within his homeland of Russia. In his later years he lived and composed in America with the Los Angeles Philharmonic Orchestra and Paramount Pictures, among others. 


\section{Carl Sandburg (1878 - 1967)}

Carl Sandburg was an American born author and writer. After dropping out of school at the age of 13, he continued his education later in life by enrolling in a local college in his hometown of Galesburg. His career as a writer began at the Chicago Daily News. A self-identified socialist, he was an avid member of the Social Democratic Party during his years living in Milwaukee. He married Lilian Steichen, the sister of Edward Steichen, during this period. Carl Sandburg is remembered for his poetry and his children's literature, most notably, Rootabaga Stories. Sandburg was awarded a Pulitzer prizes for his works The Complete Poems of Carl Sandburg, and Abraham Lincoln: The War Years.

The Arnold Newman Collection of Photographs contains an especially large number of photographs of Carl Sandburg, and it also contains a sub-collection specifically dedicated to works depicting Sandburg and his life. These photographs can be found within the Physical Organization section of the finding aid. For additional photographs of Carl Sandburg not located within this section, please refer to the sitting subject index.

\section{Other Figures}

The Arnold Newman Collection of Photographs consists of 4820 photographs of a variety of subjects, including over 1,300 identifiable sitting subjects. Due to the logistical impossibility of writing biographical notes on each sitting subject, one can find concise information regarding all identified sitting subjects in the subject index. Names, life dates, nationality and occupations have been included in this subject index. Biographical references to Igor Stravinsky and Carl Sandburg have been expanded due to their relative importance within the collection. 


\section{Effective Dates}

The dates listed for each photograph were provided by the Newman estate administration and have been verified by independent accredited appraisers. They reflect the negative dates, the time and place Arnold Newman captured the photograph but not the date of printing. The estate has identified the vintage for individual prints and this has been confirmed by accredited appraisers.

The earliest negative date is the $24^{\text {th }}$ of January, 1938 and the last negative date is the $22^{\text {nd }}$ of August, 2004. These negative dates are listed in the subject index next to the number of associated photographs for this negative date. Further, within the subject index one can find the life dates next to each identified sitter written as (BIRTH - DEATH). 


\section{Physical Description and Organization}

The Arnold New Collection of Photographs is composed of 4820 photographs. They are almost exclusively black and white gelatin silver prints, with only twelve chromogenic photographic prints. The vast majority of the photographs are printed on paper in "standard' sizes, i.e. 5"X7", 8"X10", 11"X14", 16"X20" and 20"X24". They have been arranged into a number of archival boxes.

The collection itself is composed of five individual groups of photographs:

1. The Bravo Stravinsky Book photographs.

2. The Carl Sandburg photographs.

3. Newman's Exhibition photographs.

4. Inscribed Photographs.

5. The main collection of his work.
a. Abstract photographs and landscapes.
b. Portraits.

The list below will give the reader a brief outline of the contents of each box. Detailed box lists that include individual object information can be found in each corresponding box. This will include the original print number, Newman's sitting number, AGO identification number, negative date, title and medium. A full document containing the box-list inventory can be found in archival CD form, located in Box 1, alongside a digital version of this finding aid. This CD can be copied onto one's computer, burned, or printed off at request by gallery employees. 
- $\quad$ Box 1

- $\quad$ Box 2

- $\quad$ Box 3

- $\quad$ Box 4

- $\quad$ Box 5

- $\quad$ Box 6

- $\quad$ Box 7

- $\quad$ Box 8

- $\quad$ Box 9

- Box 10

- Box 11

- Box 12

- Box 13

- Box 14

- Box 15

- Box 16

- Box 17

- Box 18

- Box 19

- Box 20

- Box 21

- Box 22

- Box 23

- $\quad$ Box 24

- Box 25

- Box 26

- $\quad$ Box 27

- Box 28

- Box 29

- Box 30

- Box 31

- Box 32

- Box 33

- Box 34

- Box 35

- $\quad$ Box 36

- Box 37

- Box 38

- $\quad$ Box 39

- Box 40

- Box 41

- Box 42

- Box 43

- Box 44
Abbado - Albers

Albright - Arman

Armitage - Avery

Bacon - Bemmelmens

Ben Gurion - Blitzstein

Bloch - Braque

Brassai - Bunschaft

Burch - Byrd

Caesarea - Caro

Carroll - Cheshire

Chicago - Comden

Commonwealth - Coward

Cowels - Davies

Davis - Desmet

DeWaart - Du Pont

Dubuffet - Ehrlich

Eisenhower - Evergood

Executive - Fleshner

Florida - Frankenthaler

Frankfurter - Geddes

Geldzhaler - Ginsberg

Glass - Gould

Graffman - Groth

Grube - Harriman

Harrison - Hiquily

Hirschfield - Holm

Holton - Indiana

Ingraham - John

Johns - Kadishman

Kahane - Kerns

Kertesz - Korman

Koussevitzky - Land

Lasker - Leether

Leger - Lifta

Lilienthal - M.I.T.

M'wami - Margolis

Marin - Mayer

Maynard - Michaels

Michals - Modica

Mondrian - Moore

Moreell - Murrow

Mushenge - Newman, A

Newman, B - Noguchi

Norman - Ollman 
- Box 45

- Box 46

- Box 47

- Box 48

- Box 49

- Box 50

- Box 51

- Box 52

- Box 53

- Box 54

- Box 55

- $\quad$ Box 56

- Box 57

- Box 58

- Box 59

- Box 60

- Box 61

- Box 62

- Box 63

- Box 64

- Box 65

- Box 66

- $\quad$ Box 67-69

- Box 70-71

- Box 72

- $\quad$ Box 73-74

- $\quad$ Box 75

- $\quad$ Box 76-77, 90-92

- $\quad$ Box 78-89
Omnicorp - Peat

Pei - Podhoretz

Poling - Rabin

Rand - Rickey

Ridgley - Rome

Romney - Rouault

Rovem - Sandburg

Sanders - Seay

Segal - Segal

Segovia - Sills

Silver - Smithsonian

Snaith - St. Marie

Stamps - Sterling

Stern - Strand

Stravinsky - Tandy

Tanning - Todd

Tourel - Universal

Upjohn - Walker

Wallace - Weber

Weicker - West Palm Beach

Weston - Wolf

Wolfensohn - Zworykin

Selected Abstracts and Landscapes

Bravo Stravinsky

Carl Sandburg

Inscribed Photographs

Exhibition/Installation Photographs

Oversized Photographs

Masonite Mounted Photographs 


\section{Markings}

The photographs found within the Arnold Newman Collection of Photographs display a variety of markings on both the recto and verso of each photograph. These markings can be attributed to the original use of the photographs, as many were created for reproduction in periodic print publications and not intended as exhibition prints to be hung on a gallery wall. Like many photographers, Newman would "work" his photographs; highlighting areas that required special treatment in the development process. Further, Newman kept consistent records, and he would inscribe information onto the back of his photographs to facilitate contact with his many clients.

The following ten pages will explain many of the markings that can be found on individual prints within the Arnold Newman Collection of Photographs. Unfortunately, not all the markings can be deciphered, and many are illegible. The photographic examples provided in this section will provide the reader with an idea of what they will find while investigating Newman's photographs. To assist the reader in understanding these markings, we will define some key terms and vocabulary.

Recto: Image side of the photograph.

Verso: Reverse side of a photograph.

Inscription: Any information written onto a photograph.

Burning/ Dodging: During the height of the film era of photography, photographers would work in darkrooms and would physically determine the quality of a photographic print by manipulating light transmitted through the photographic negative onto light sensitive paper.

Burning: A term used for adding exposure to a selected area of the photograph to increase darkness. 
Dodging: The opposite action of burning. By preventing light from hitting a selected area of image, this area of the photograph develops lighter. In some instances, photographers would use coloured pencil to highlight what areas of a print required burning and dodging for the subsequent attempt. See Figure 17 for more information.

Cropping: A popular photographic technique that occurs when a photographer isolates an area of a photograph and removes any outlying information. This effectively reframes the photograph measurably into a more appealing aesthetic.

Artist's Stamp: A stamp located on the verso of a photograph which generally includes the photographer's name, location of studio and contact information. It is often used as a mark of copyright and an easier method of signing a photograph for authentication. The photographs below display the variety of stamps that can be found in the Arnold Newman Collection of Photographs. 


\begin{tabular}{|c|c|}
\hline 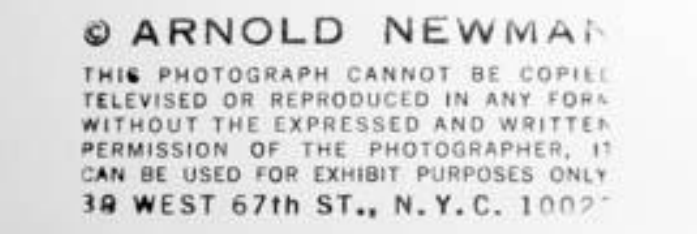 & $\begin{array}{l}\text { PLEASE CREDIT PHOTOGRAPH Th } \\
\text { C AR NOLD NEW I. A A Y } \\
20 \text { EAST } 84^{\text {TH }} \text { ST., NEW YORK, N.Y. }\end{array}$ \\
\hline Figure 2 & Figure 3 \\
\hline $\begin{array}{l}\text { PLEASE CREUI PHOTOGRAPH } \\
\text { ARNOLD NE WMAN }\end{array}$ & $\begin{array}{l}39 \text { WEST } 67 \text { STREET } \\
\text { NEW, YORK, N. Y. } 10023\end{array}$ \\
\hline Figure 4 & Figure 5 \\
\hline 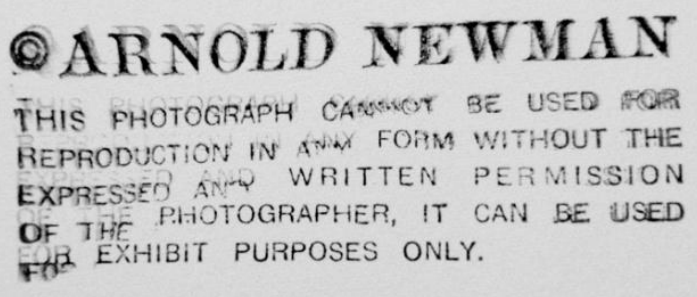 & \\
\hline Figure 6 & Figure 7 \\
\hline
\end{tabular}




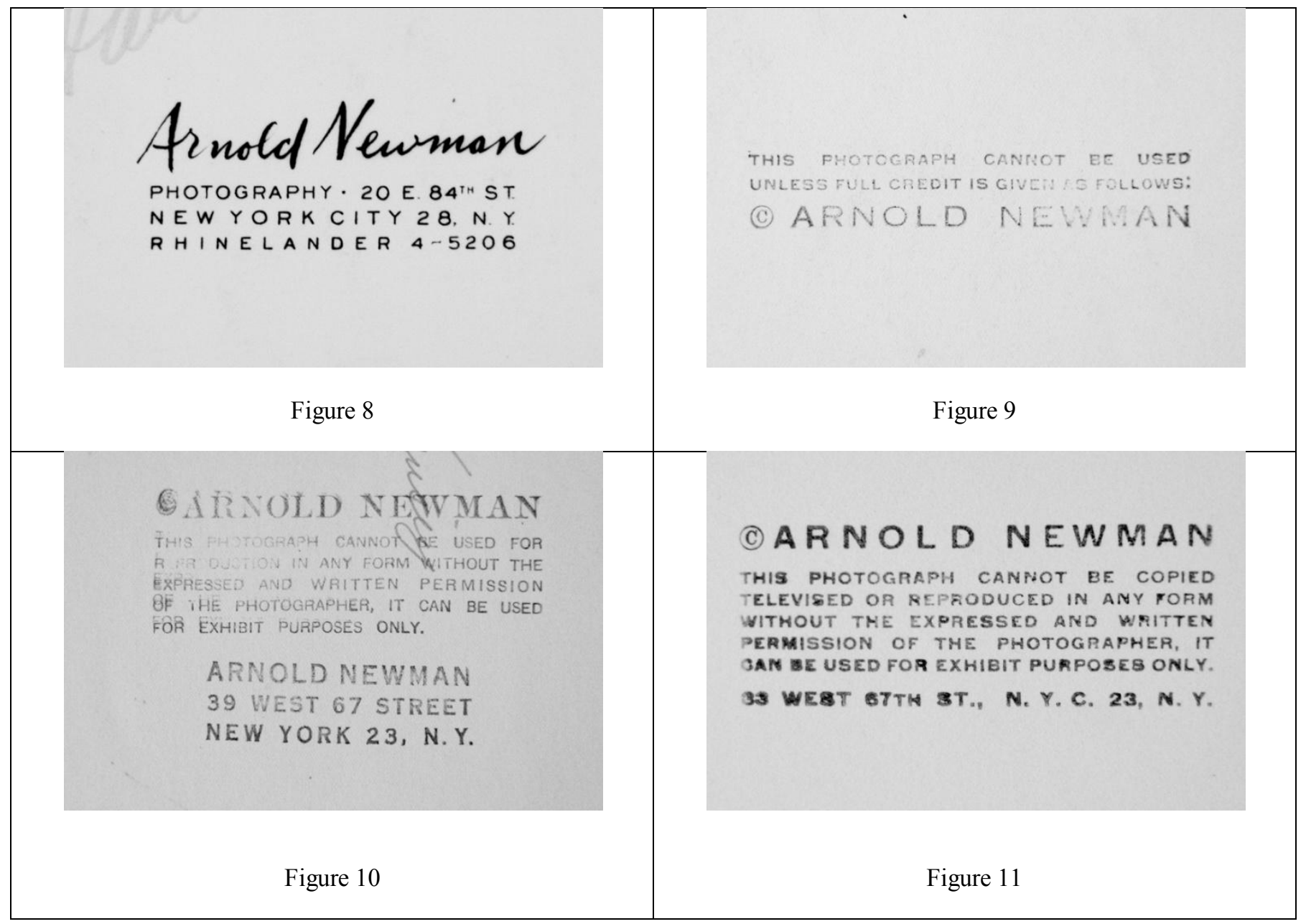

Sitting Book Number: Arnold Newman made efforts to keep records of his photographs. These numbers were also included in a sitting book where he wrote down basic information about the session. The sitting book number associated the individual print with the session, which may have resulted in a number of related photographs.

Print Number: This number was taken from the estate records and verso of the photographs when the collection was acquired. There does not seem to be any organizational intent behind the print number, aside from the fact that the prints were in this inventory order when acquired by the Art Gallery of Ontario. 
Signature: The signature of the photograph is found on either the recto or verso of a photograph. Arnold Newman had a number of different signatures that he would use. This more than likely has to do with each photograph's intended usage. Below you can see the different ways Newman would sign his photographs. We have the simple initials, often found on the verso as well as the full signature which could be found on the verso or on the recto.

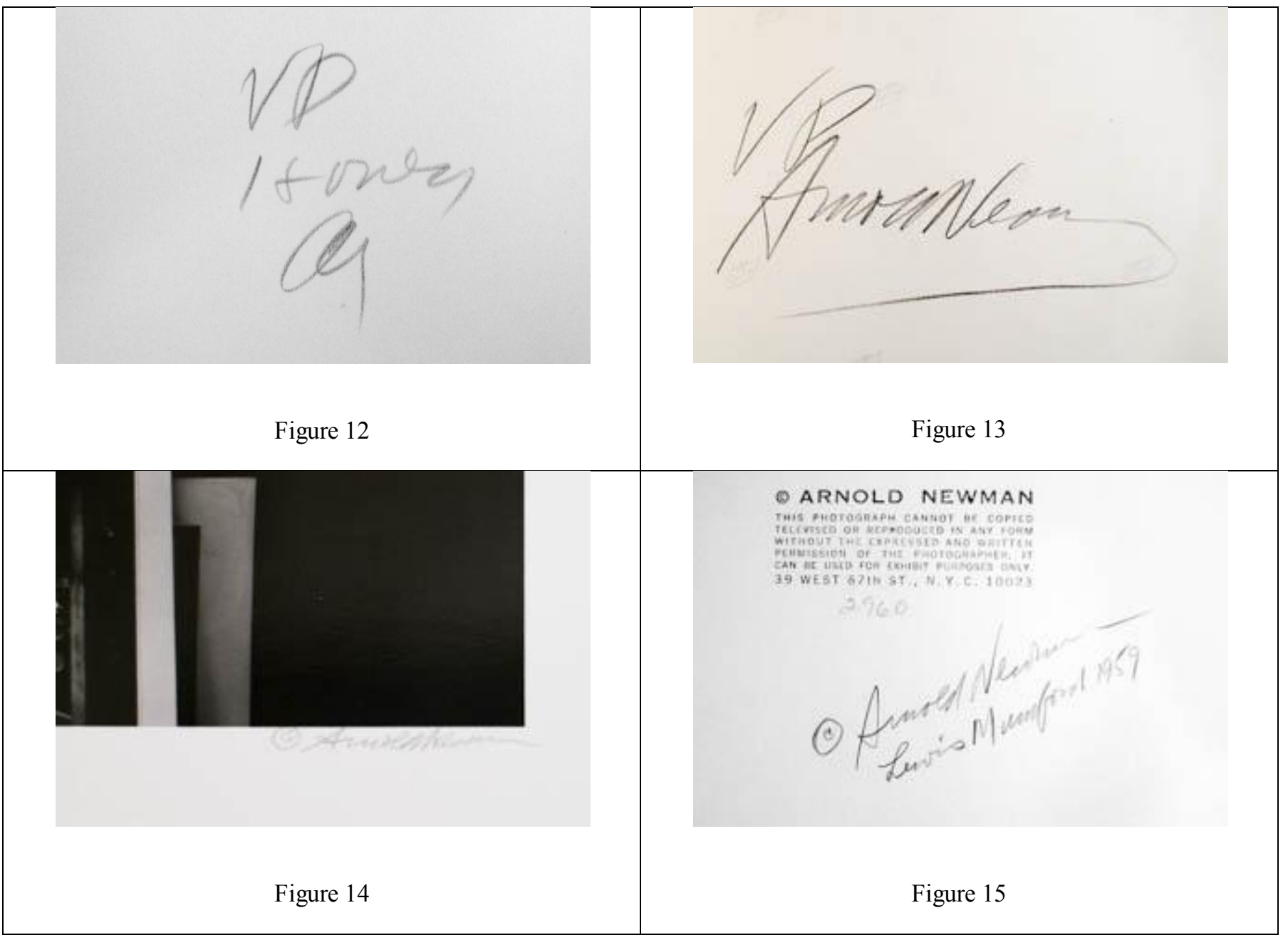




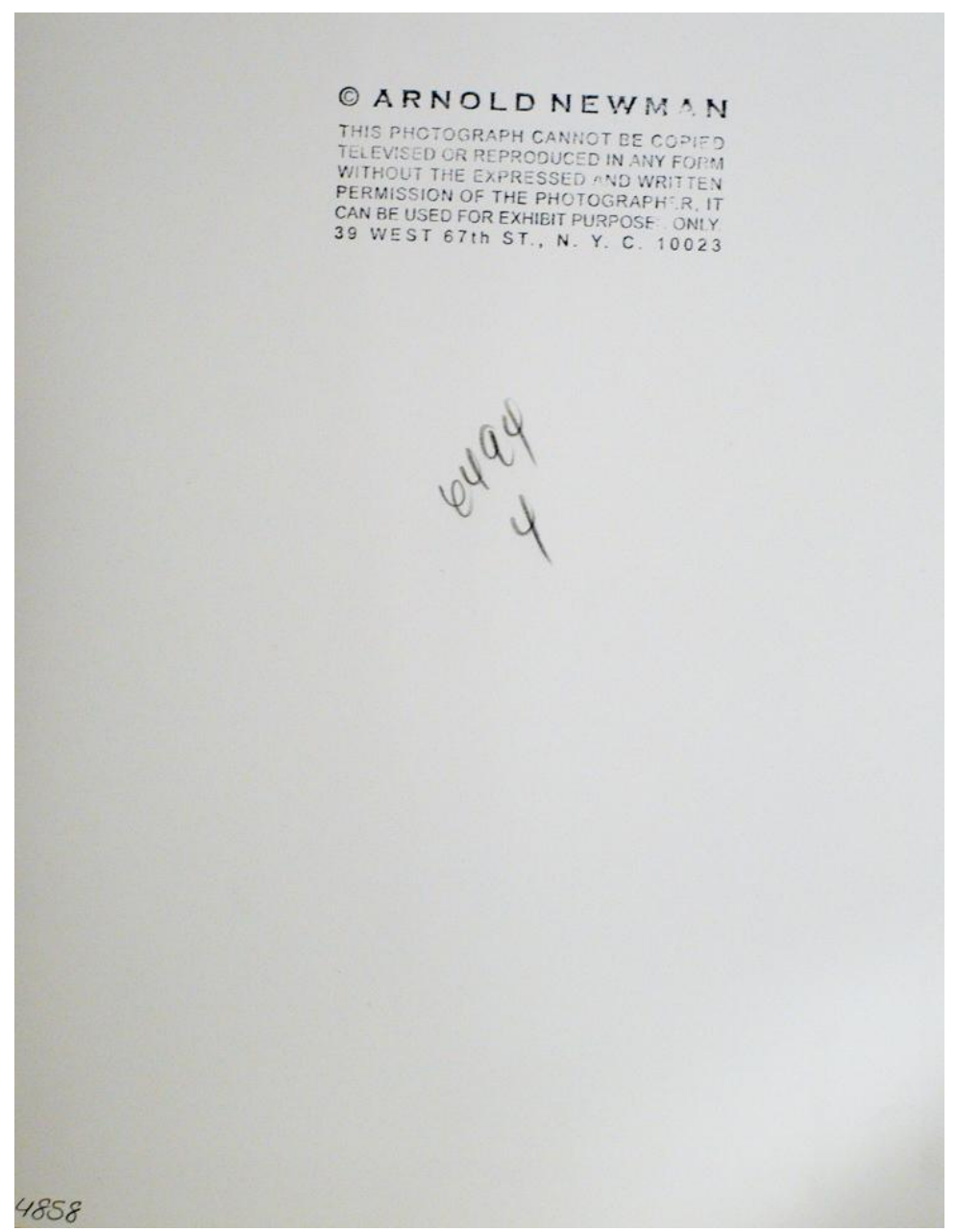

Figure 16

Figure 16 represents how the markings are generally arranged on the photographs in the Arnold Newman Collection of Photographs. In the bottom left hand corner we can find the Print Number, 4858. The Sitting Book number can be found in the center, 6494 with an accompanying number, 4 . There are often unidentified numbers connected with the sitting book number. The Artist's Stamp is located in the top center and reads: “C ARNOLD NEWMAN/THIS PHOTOGRAPH CANNOT BE COPIED/TELEVISED OR REPRODUCED IN ANY FORM/WITHOUT THE EXPRESSED AND WRITTEN/PERMISSION OF THE PHOTOGRAPHER, IT/CAN BE USED FOR EXHIBIT PURPOSES ONLY./39 WEST 67th ST., N.Y.C. 10023.” These stamps can be found on the verso of a photograph, they are not necessarily level or aligned with the bottom of the photograph. These three sets 
of data, print number, sitting book number and artist stamp, can be found on the vast majority of prints, and is often the only information provided.

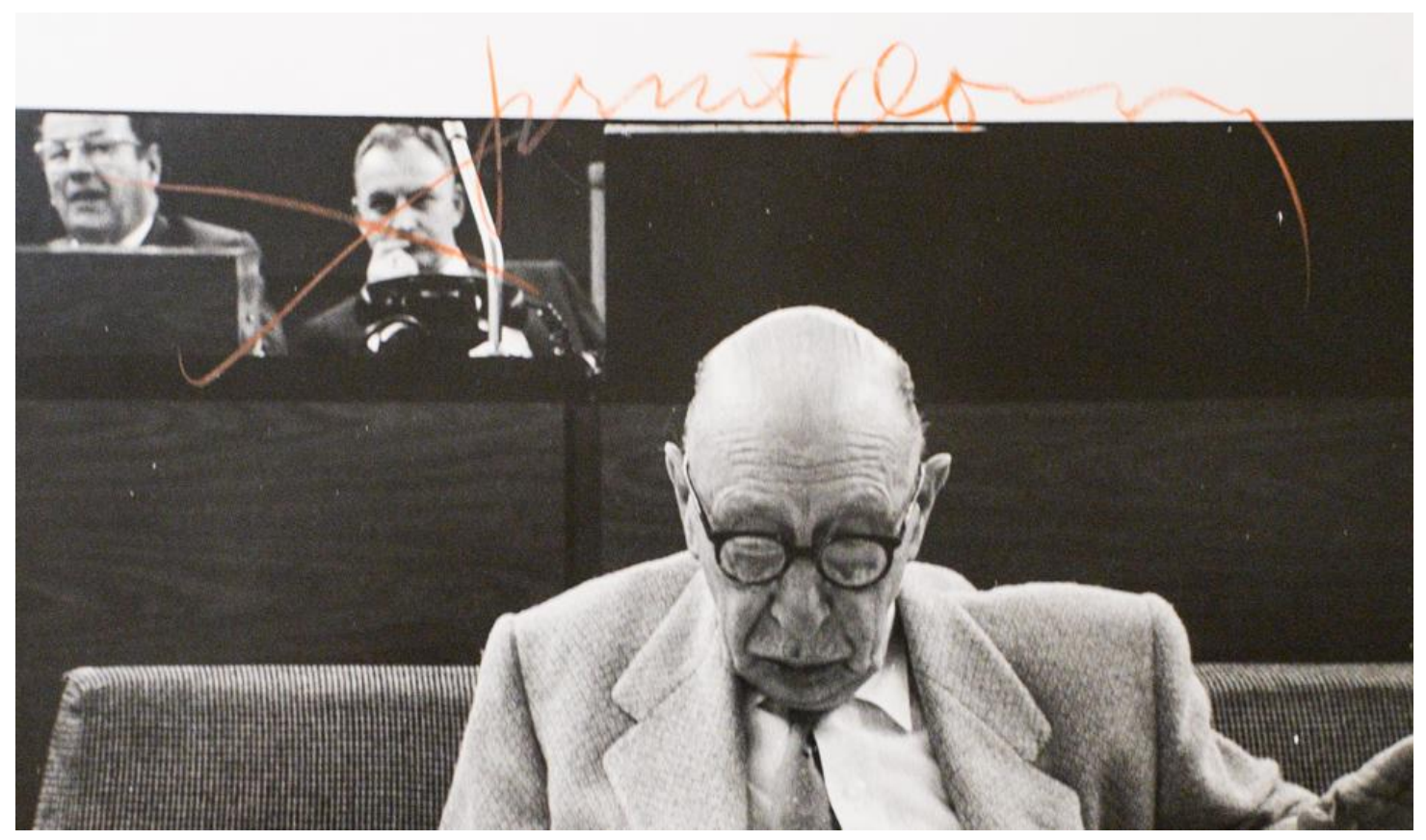

Figure 17

On Figure 17 we can see some markings over the subject's face. These are "work" markings used by Arnold Newman to determine how the photograph would be burned and dodged during the development stage. By physically marking the photograph in this way, the printer could use it as a map to add light to this area of the image thereby darkening the two figures so they no longer distract the viewer from the figure of Stravinsky. There are few prints with these types of markings within the collection; this can generally be attributed to the fact that work prints are often discarded after use. 


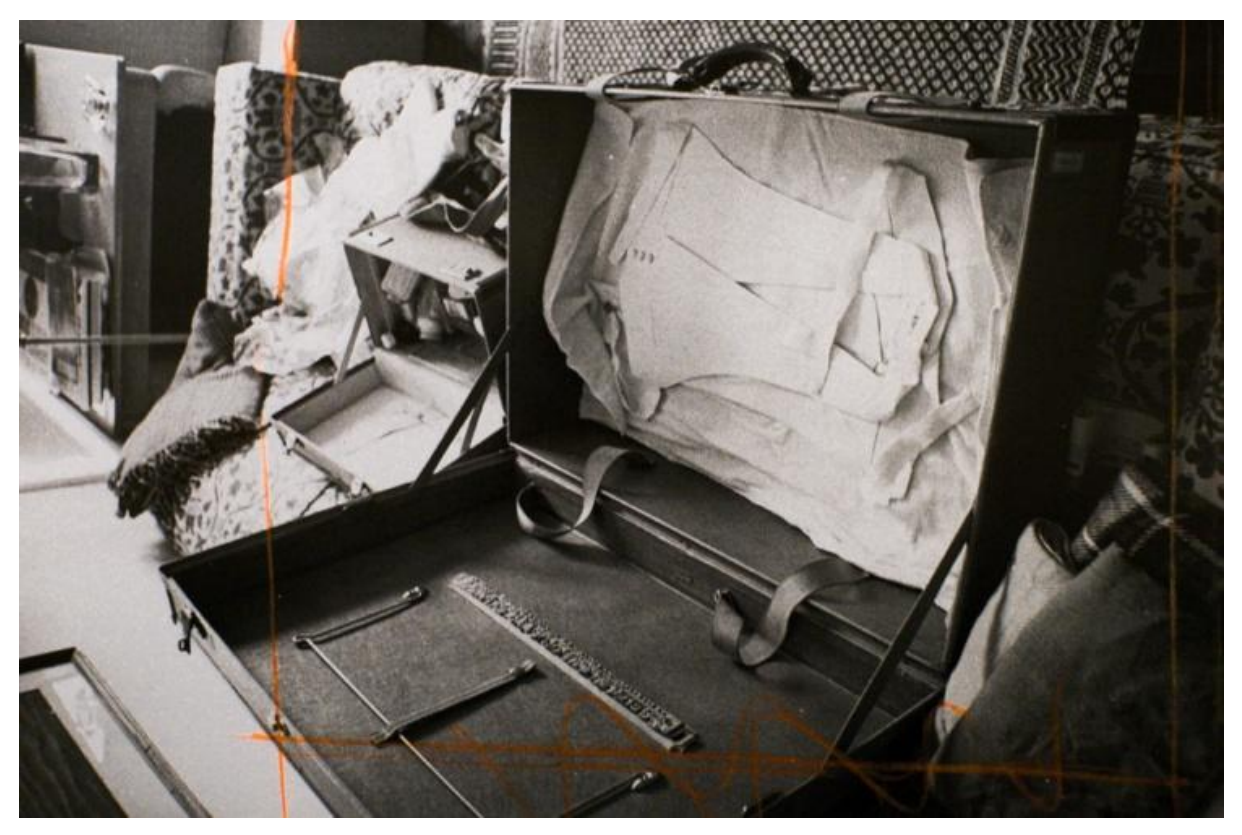

Figure 18

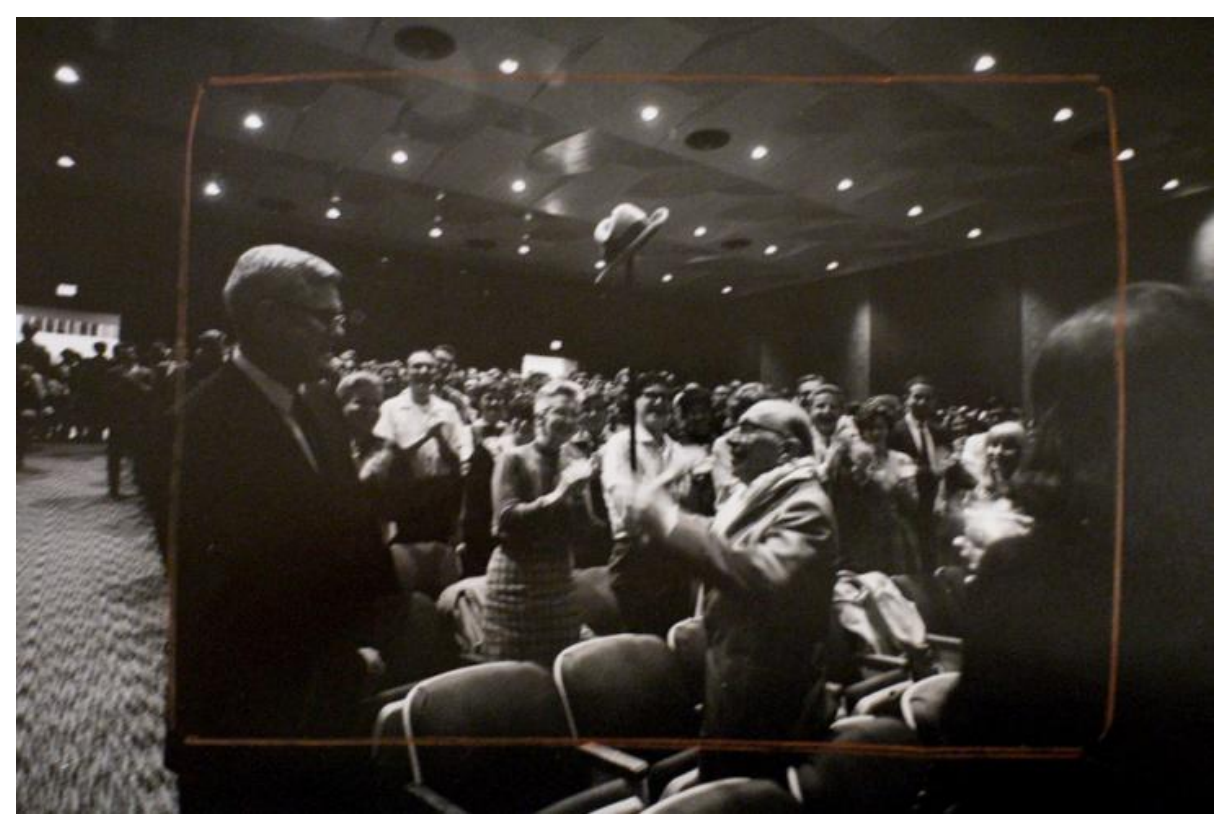

Figure 19 
Figure 18 and 19 are two of the prints found in the Bravo Stravinsky book dummy. The many markings found alongside the photograph help the book publisher and binders determine where the photograph requires cropping to ensure the publisher can create a high quality copy. Many of the photographs contain a myriad of markings on the verso as displayed above. 


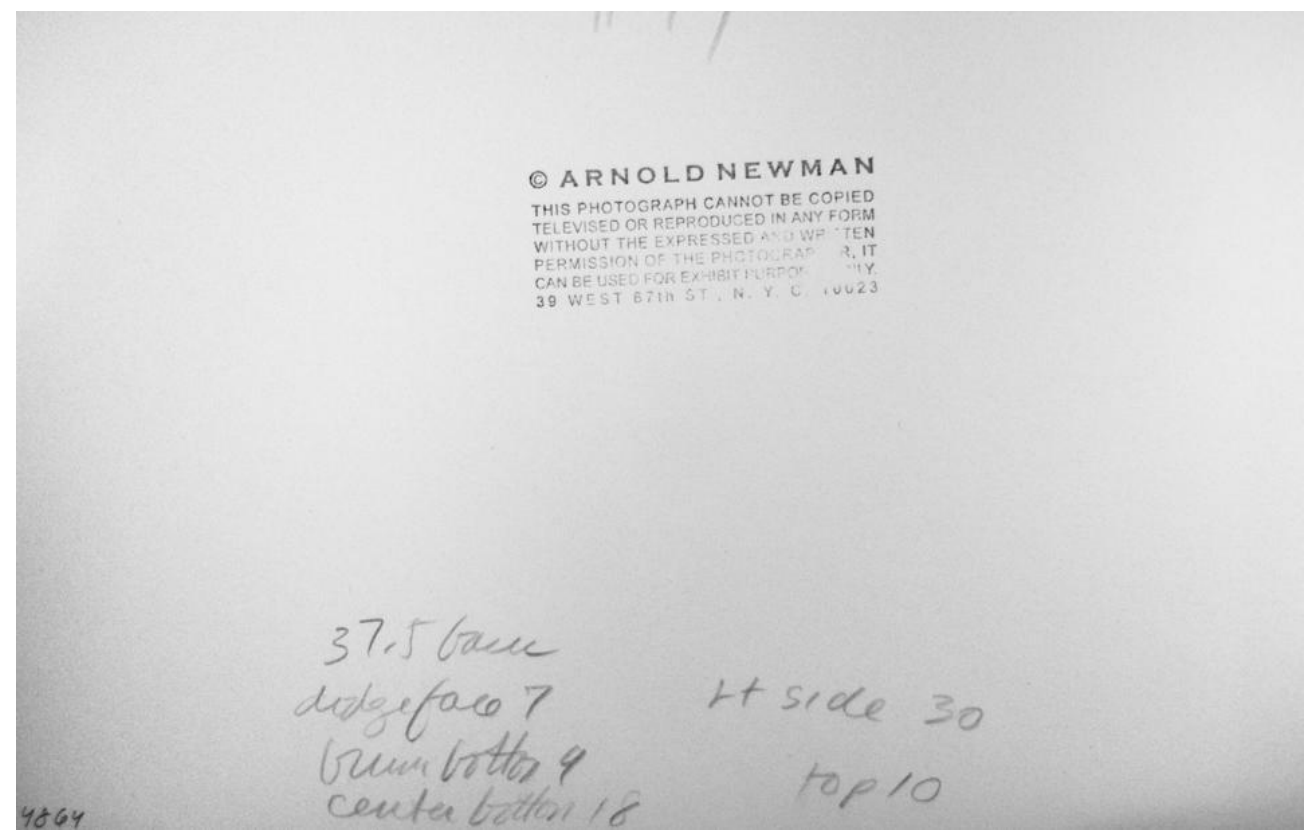

Figure 20

With Figure 20 you can see that there is quite a bit more information. Unfortunately, the vast majority of the information on this print cannot be verified. Like the first example print, sitting book number, print number and artist stamp are provided. There is a string of numbers and letters and much of the inscription speaks of dodging and burning. More than likely this information was used by Newman to determine the exposure and development times of the print.

While these are just a few examples of the types of markings you will find in the Arnold Newman Collection of Photographs, Newman was a consistent printer, which is reflected in his markings. Only a few prints show markings which fall outside of these examples. Additional information on each individual print may be found in the box list index, the sitting subject index and by referencing the digitized Arnold Newman Sitting Book. See the table of contents for the locations of these resources. 


\section{Photographs}

The following pages will give the reader an overview of photographic examples of Newman's working method. Each page will reference a single sitting subject, represented by a number of variations. The first page will display four images containing identifying data. The second page will give additional information found on the verso (not shown).

Picasso, Pablo (1881 - 1973)

\section{Spanish Painter, Sculptor, Printmaker and Ceramicist}

There are numerous photographs of Pablo Picasso in the Newman Collection and the collection includes variants of each photograph, including full sized, un-cropped versions of many prints. There are also a number of photographs of Picasso in his studio, the subject surrounded by his artwork. Figures $21-24$, illustrated below, are a group of variants of a photograph used by the Art Gallery of Ontario for advertising an exhibition during the summer of 2012. 


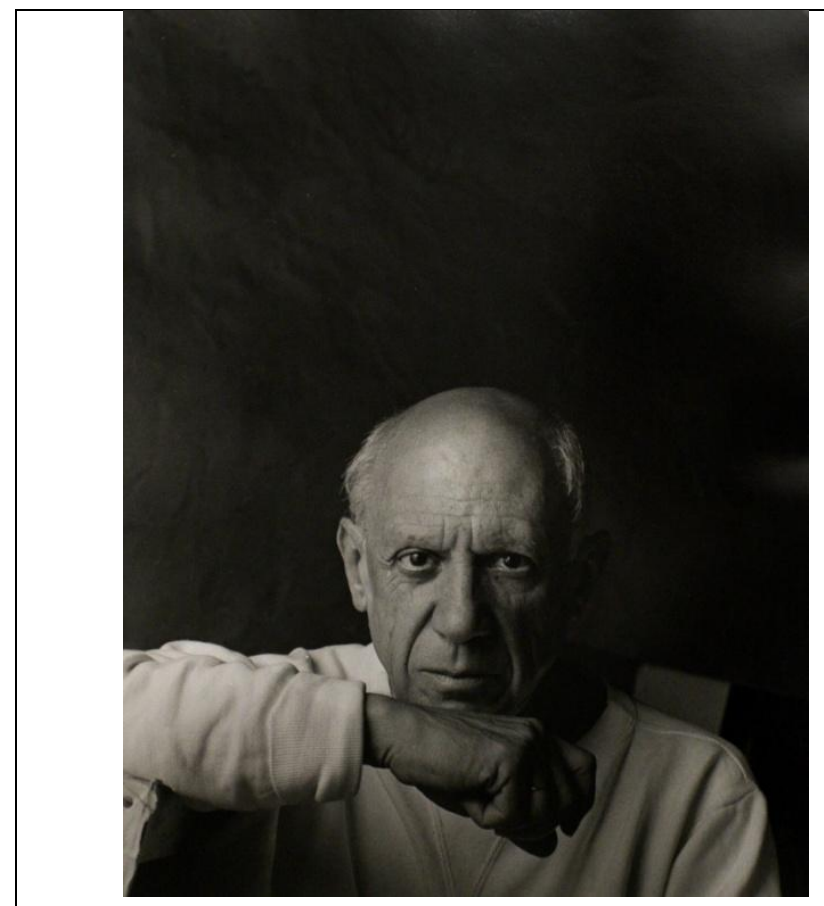

Figure 21

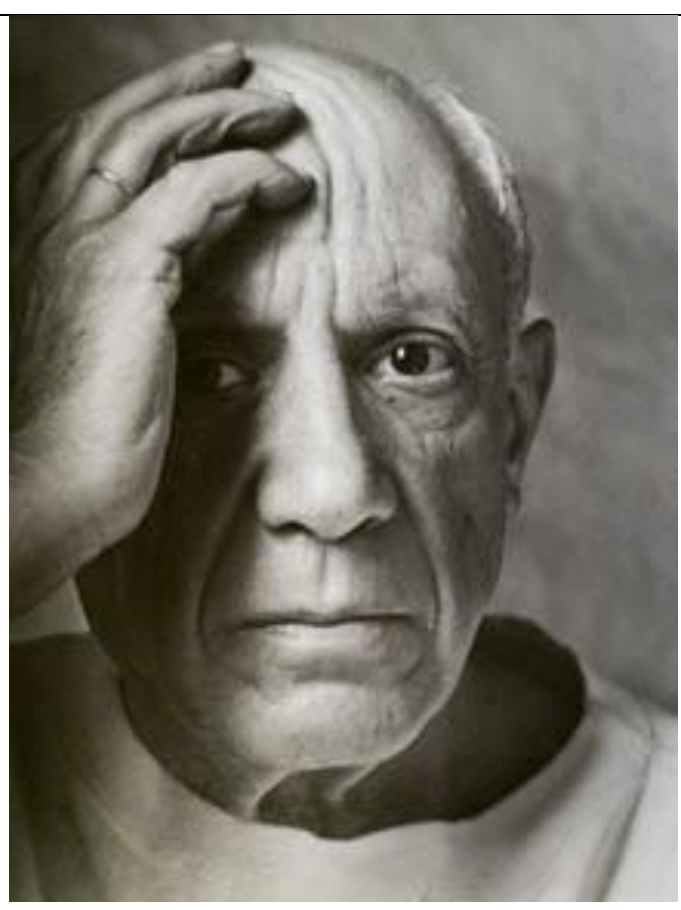

Figure 22

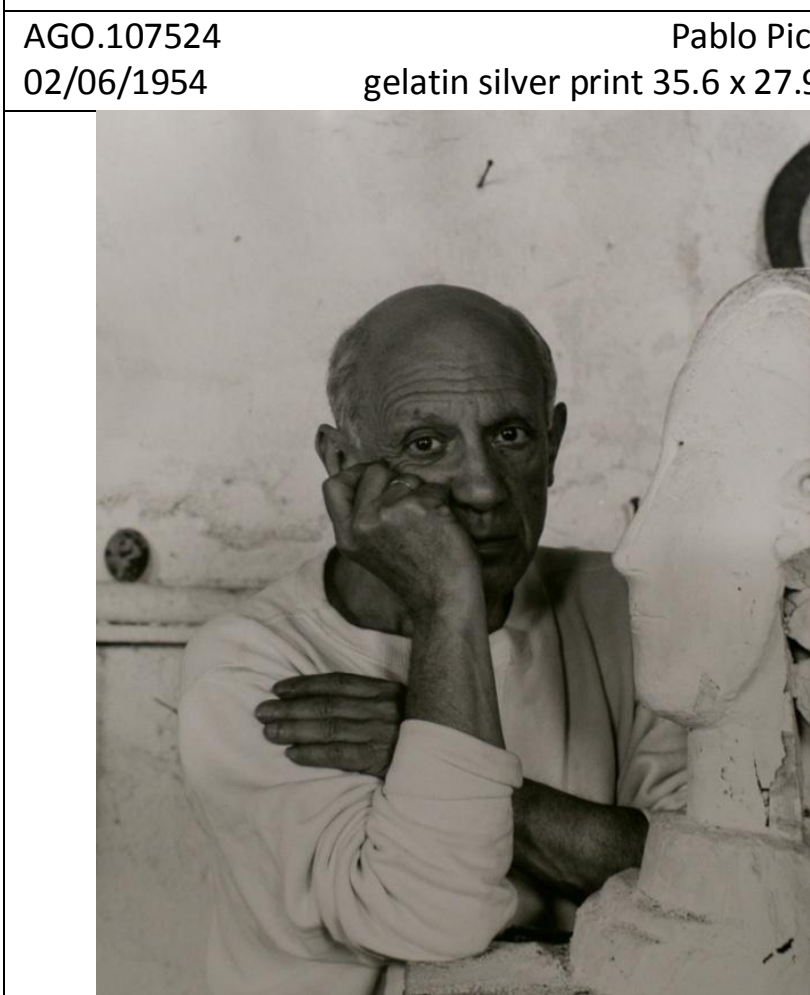

Figure 23
AGO.107538

02/06/1954
Pablo Picasso

gelatin silver print $43.2 \times 35.6 \mathrm{~cm}$

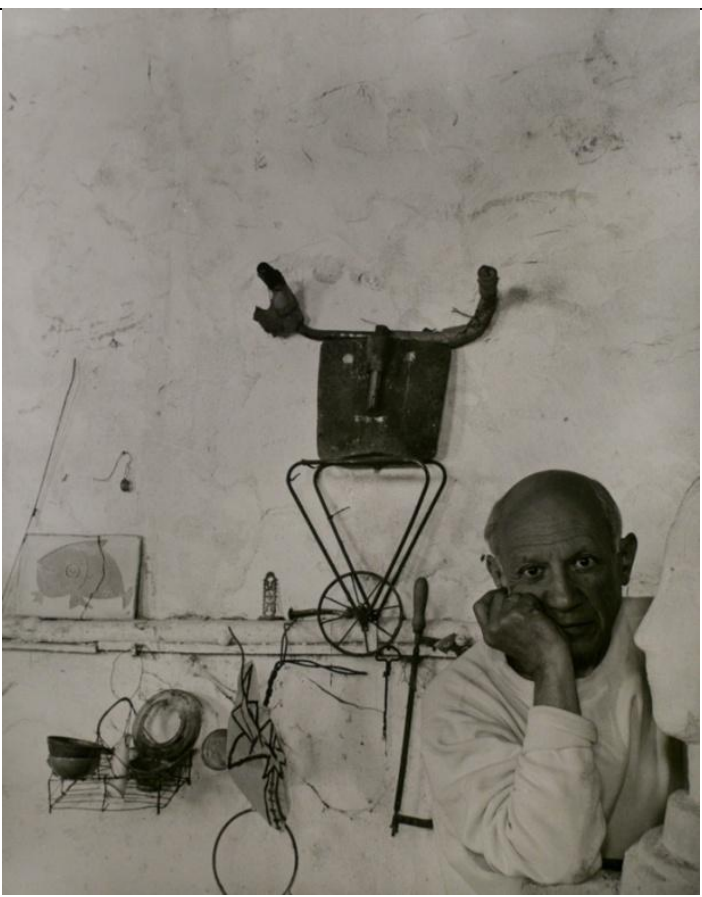

Figure 24 


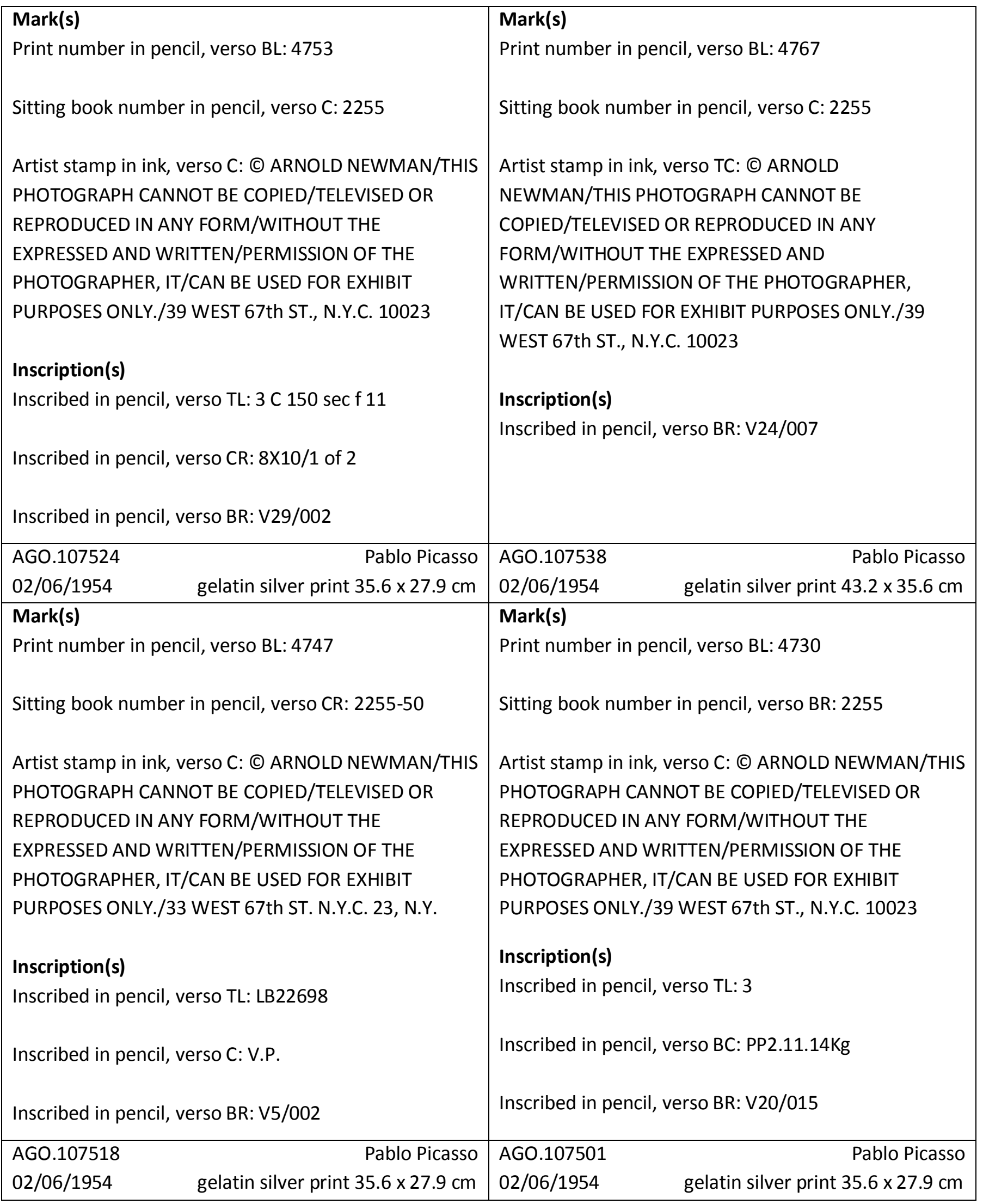


Stravinsky, Igor (1882 - 1971)

\section{Russian American Composer, Pianist and Conductor}

Many sources consider Igor Stravinsky to be one of Newman's most famous subjects. The photograph of Stravinsky sitting at his grand piano validated Newman as photographer of note internationally. Interestingly, the client that hired him to shoot the photograph failed to appreciate the image and refused to publish it, opting for a variant. The Newman Collection has this image in a number of sizes, including a number of variants. Further, Newman would continue to take portraits of Igor Stravinsky throughout his life, even designing and publishing a book on the work focused around Stravinsky. The Arnold Newman Collection of Photographs has a copy of the book dummy for Bravo Stravinsky. For additional information on Bravo Stravinsky please see the entry in the annotated bibliography. 


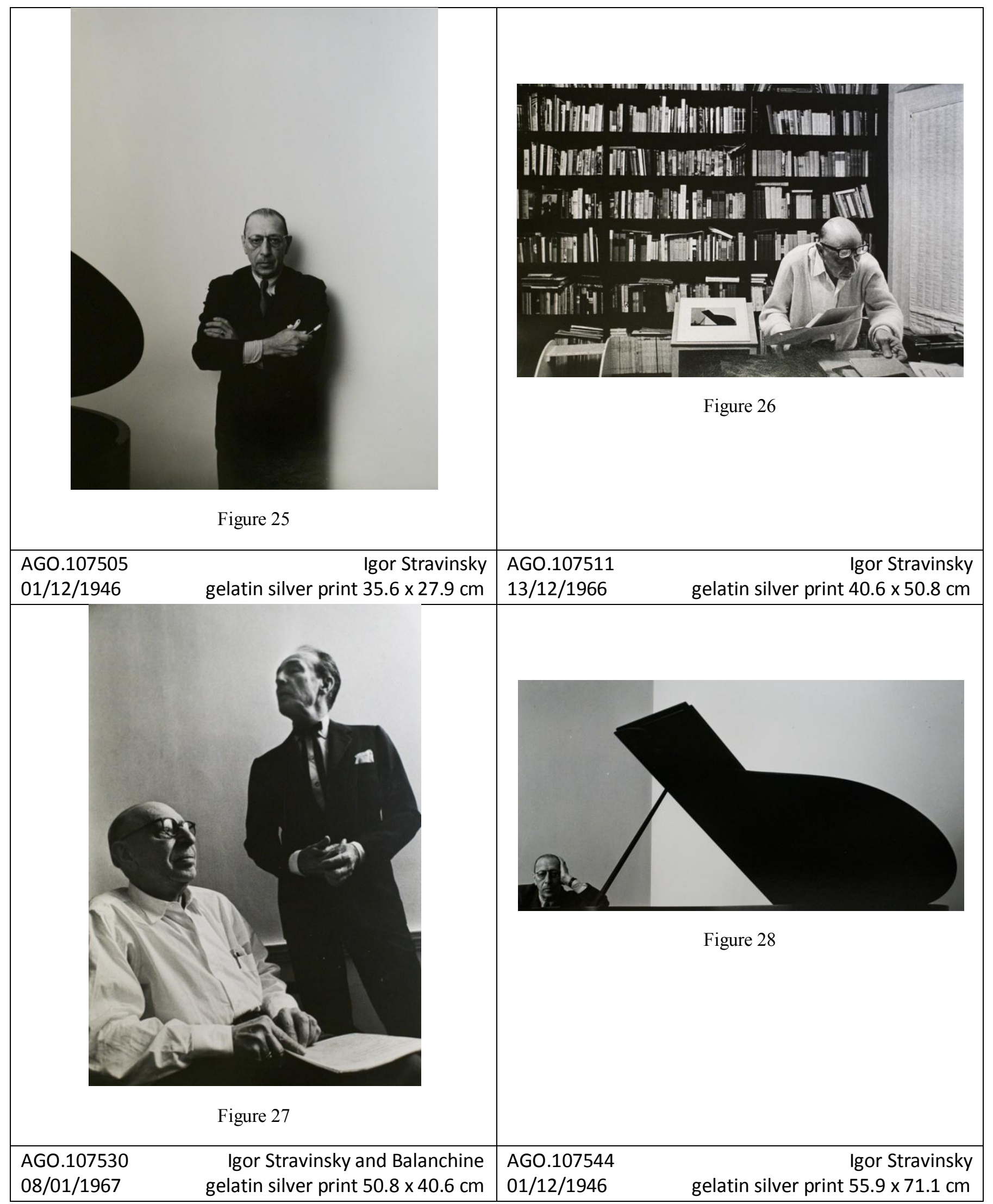




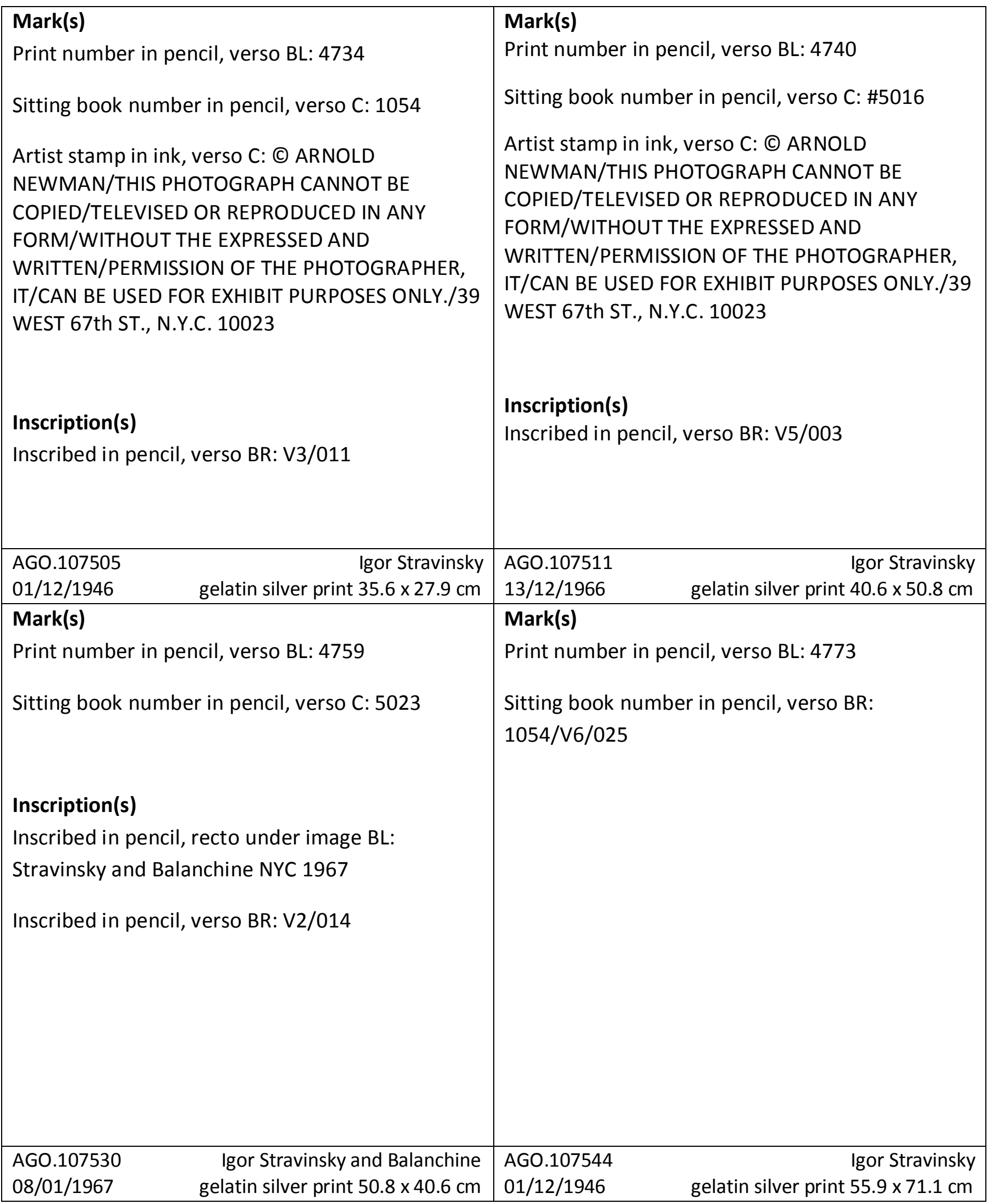


O'Keefe, Georgia (1887 - 1986)

American Artist

Stieglitz, Alfred (1864 - 1946)

American Photographer

Figure 29 and 31 are earlier portraits by Newman, Figure 29 being one of the few portraits taken of Stieglitz and O'Keefe together in the collection. O'Keefe would have her portrait taken by Newman multiple times throughout his career, including a session that was shot at O'Keefe's ranch in Arizona. The Arnold Newman Collection of Photographs contains a number of variants in different sizes and different printing conditions. They can be found by looking up either sitting subject in the subject index.

Figure 30 and figure 32 are taken at a later date by Newman, of O'Keefe at her farm in Arizona. The Newman collection represents such a wide range of Newman's career that there are often multiple shoots of the same subject throughout their lives, an invaluable resource for researchers interested in Newman's career. 


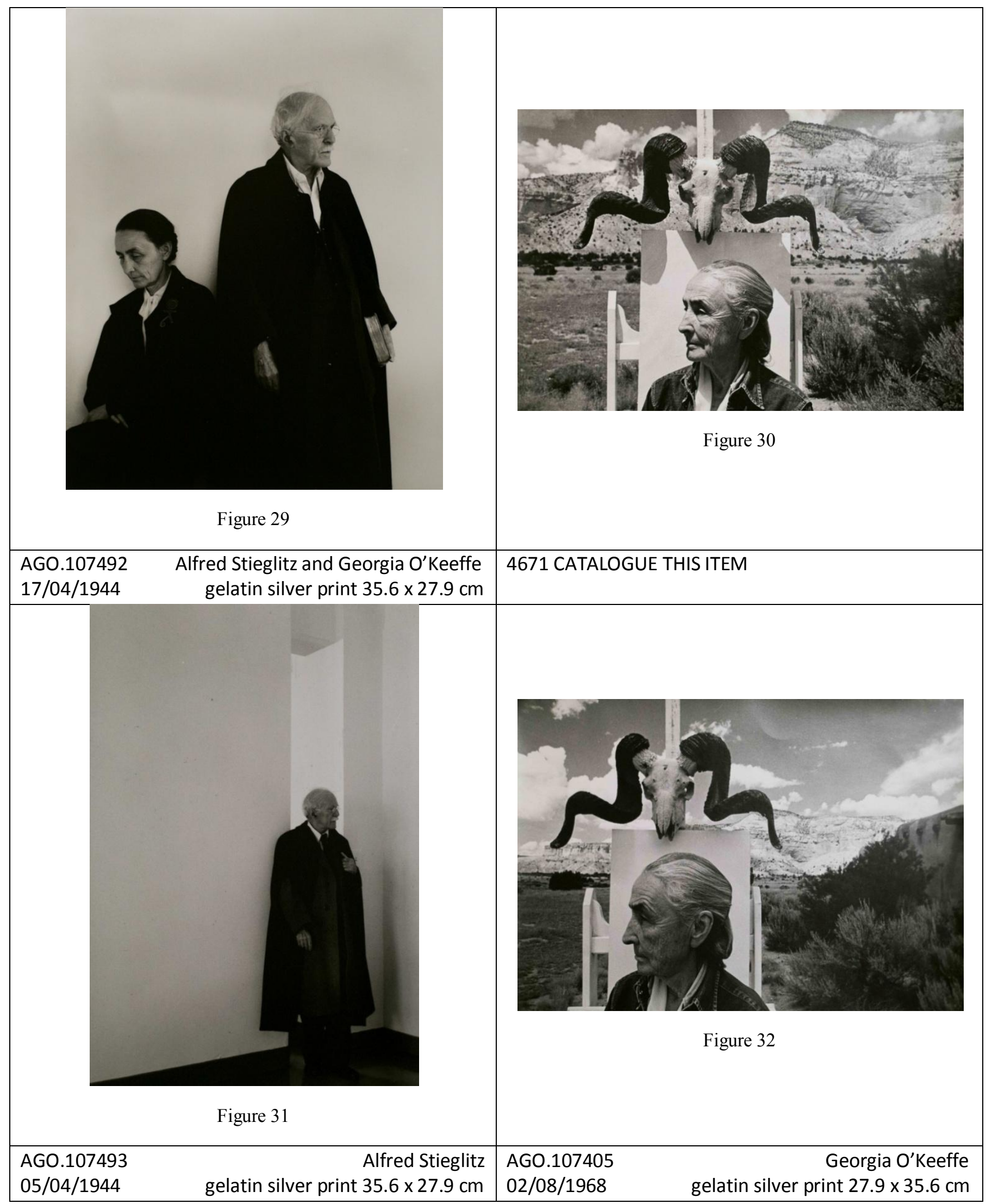




\begin{tabular}{|c|c|}
\hline Mark(s) & Mark(s) \\
\hline Print number in pencil, verso BL: 4721 & Print number in pencil, verso BL: 4671 \\
\hline Sitting book number in pencil, verso C: 895 & Sitting book number in pencil, verso C: 5233 \\
\hline Artist stamp in ink, verso BR: C ARNOLD & Artist stamp in ink, verso C: (C) ARNOLD NEWMAN/39 \\
\hline NEWMAN/THIS PHOTOGRAPH CANNOT BE & WEST 67 STREET/NEW YORK 23, N. Y. 10023 \\
\hline $\begin{array}{l}\text { COPIED/TELEVISED OR REPRODUCED IN ANY } \\
\text { FORM/WITHOUT THE EXPRESSED AND }\end{array}$ & \\
\hline WRITTEN/PERMISSION OF THE PHOTOGRAPHER, & Inscription(s) \\
\hline $\begin{array}{l}\text { IT/CAN BE USED FOR EXHIBIT PURPOSES ONLY./39 } \\
\text { WEST 67th ST., N.Y.C. } 10023\end{array}$ & Inscribed in pencil, verso BR: V11/004 \\
\hline Inscription(s) & \\
\hline AGO.107492 Alfred Stieglitz and Georgia O'Keeffe & Georgia O’Keeffe \\
\hline 17/04/1944 gelatin silver print $35.6 \times 27.9 \mathrm{~cm}$ & gelatin silver print $27.9 \times 35.6 \mathrm{~cm}$ \\
\hline Mark(s) & Mark(s) \\
\hline Print number in pencil, verso BL: 4722 & Print number in pencil, verso BL: 4670 \\
\hline Sitting book number in pencil, verso C: 883 & Sitting book number in pencil, verso C: 5233 \\
\hline Artist stamp in ink, verso CR: C ARNOLD & Artist stamp in ink, verso CR: (C) ARNOLD \\
\hline NEWMAN/THIS PHOTOGRAPH CANNOT BE & NEWMAN/THIS PHOTOGRAPH CANNOT BE \\
\hline COPIED/TELEVISED OR REPRODUCED IN ANY & COPIED/TELEVISED OR REPRODUCED IN ANY \\
\hline FORM/WITHOUT THE EXPRESSED AND & FORM/WITHOUT THE EXPRESSED AND \\
\hline WRITTEN/PERMISSION OF THE PHOTOGRAPHER, & WRITTEN/PERMISSION OF THE PHOTOGRAPHER, \\
\hline IT/CAN BE USED FOR EXHIBIT PURPOSES ONLY./39 & IT/CAN BE USED FOR EXHIBIT PURPOSES ONLY./39 \\
\hline WEST 67th ST., N.Y.C. 10023 & WEST 67th ST., N.Y.C. 10023 \\
\hline Inscription(s) & Inscription(s) \\
\hline Inscribed in pencil, verso BR: V2/001 & Inscribed in pencil, verso BR: V10/009 \\
\hline $\begin{array}{ll}\text { Alfred Stieglitz } \\
\end{array}$ & Georgia O’Keeffe \\
\hline gelatin silver print $35.6 \times 27.9 \mathrm{~cm}$ & gelatin silver print $27.9 \times 35.6 \mathrm{~cm}$ \\
\hline
\end{tabular}


Moore, Henry (1898 - 1986)

\section{English Sculptor}

Henry Moore is an important subject in the Arnold Newman Collection considering the relationship the Art Gallery of Ontario has with the late artist. Many of his works are on display at the AGO, including a public work, Two Large Forms (1966-1969) on the northeast corner of the gallery's property. Arnold Newman took a substantial number of portraits of the artist, of which many are represented in the Arnold Newman Collection of Photographs. For information on the portraits of Moore, look for his entry in the sitting subject index. 


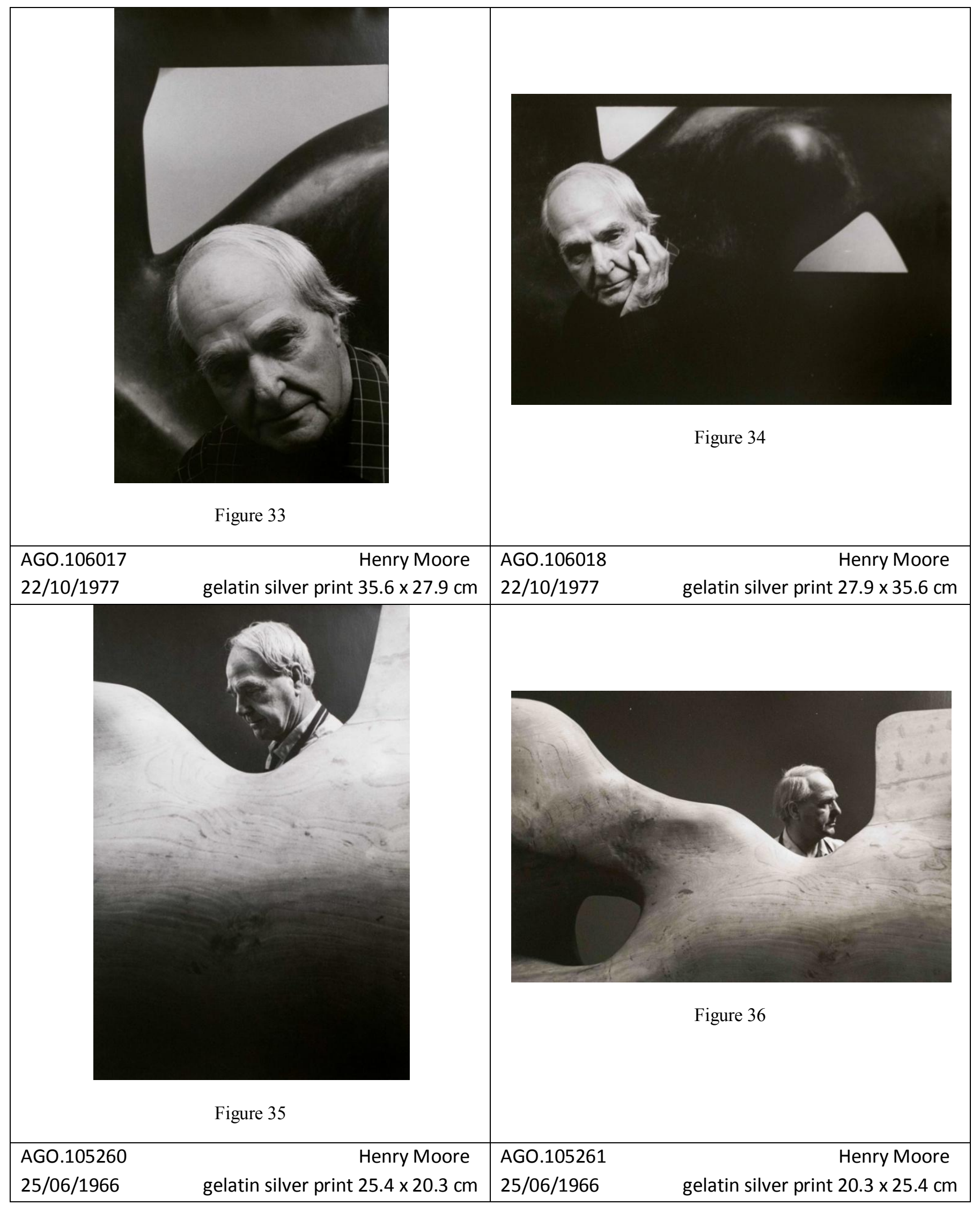




\begin{tabular}{|c|c|}
\hline Mark(s) & Mark(s) \\
\hline Print number in pencil, verso BL: 2886 & Print numbers in pencil, verso BL: 2887 \\
\hline Sitting book number in pencil, verso CL: 6399 & Sitting book number in pencil, verso CL: 6399 \\
\hline Artist stamp in ink, verso C: (C) ARNOLD NEWMAN/THIS & Artist stamp in ink, verso C: (C) ARNOLD NEWMAN/THIS \\
\hline PHOTOGRAPH CANNOT BE COPIED/TELEVISED OR & PHOTOGRAPH CANNOT BE COPIED/TELEVISED OR \\
\hline REPRODUCED IN ANY FORM/WITHOUT THE & REPRODUCED IN ANY FORM/WITHOUT THE \\
\hline EXPRESSED AND WRITTEN/PERMISSION OF THE & EXPRESSED AND WRITTEN/PERMISSION OF THE \\
\hline PHOTOGRAPHER, IT/CAN BE USED FOR EXHIBIT & PHOTOGRAPHER, IT/CAN BE USED FOR EXHIBIT \\
\hline PURPOSES ONLY./39 WEST 67th ST., N.Y.C. 10023 & PURPOSES ONLY./39 WEST 67th ST., N.Y.C. 10023 \\
\hline Inscription(s) & Inscription(s) \\
\hline Inscribed in pencil, verso C: 1 & No inscriptions. \\
\hline Henry Moore & AGO.106018 \\
\hline gelatin silver print $35.6 \times 27.9 \mathrm{~cm}$ & gelatin silver print $27.9 \times 35.6 \mathrm{~cm}$ \\
\hline Mark(s) & Mark(s) \\
\hline Print number in pencil, verso BL: 1852 & Print number in pencil, verso BL: 1853 \\
\hline Sitting book number in pencil, verso C: 4976 & Sitting book number in pencil, verso CL: 4976 \\
\hline Artist stamp in ink, verso TR: (C ARNOLD & Artist stamp in ink, verso C: @ ARNOLD NEWMAN/THIS \\
\hline NEWMAN/THIS PHOTOGRAPH CANNOT BE & PHOTOGRAPH CANNOT BE COPIED/TELEVISED OR \\
\hline COPIED/TELEVISED OR REPRODUCED IN ANY & REPRODUCED IN ANY FORM/WITHOUT THE \\
\hline FORM/WITHOUT THE EXPRESSED AND & EXPRESSED AND WRITTEN/PERMISSION OF THE \\
\hline WRITTEN/PERMISSION OF THE PHOTOGRAPHER, & PHOTOGRAPHER, IT/CAN BE USED FOR EXHIBIT \\
\hline IT/CAN BE USED FOR EXHIBIT PURPOSES ONLY./39 & PURPOSES ONLY./39 WEST 67th ST., N.Y.C. 10023 \\
\hline WEST 67th ST., N.Y.C. 10023 & \\
\hline & Inscription(s) \\
\hline Inscription(s) & Inscribed in pencil, verso CL: GAL/FINAL \\
\hline No inscriptions. & \\
\hline Henry Moore & AGO.105261 \\
\hline gelatin silver print $25.4 \times 20.3 \mathrm{~cm}$ & gelatin silver print $20.3 \times 25.4 \mathrm{~cm}$ \\
\hline
\end{tabular}


Sandburg, Carl (1878 - 1967)

\section{American Writer and Editor}

These photographs are some of the many portraits Newman would take of Carl Sandburg throughout his career. Sandburg and Newman would become friends through their mutual interactions together. This friendship is well documented in the Arnold Newman Collection of Photographs; there are some thirty photographs of Sandburg represented in the collection, alongside an additional body of work for an unpublished book. For more information on these prints, refer to his entry in the sitting subject index. 


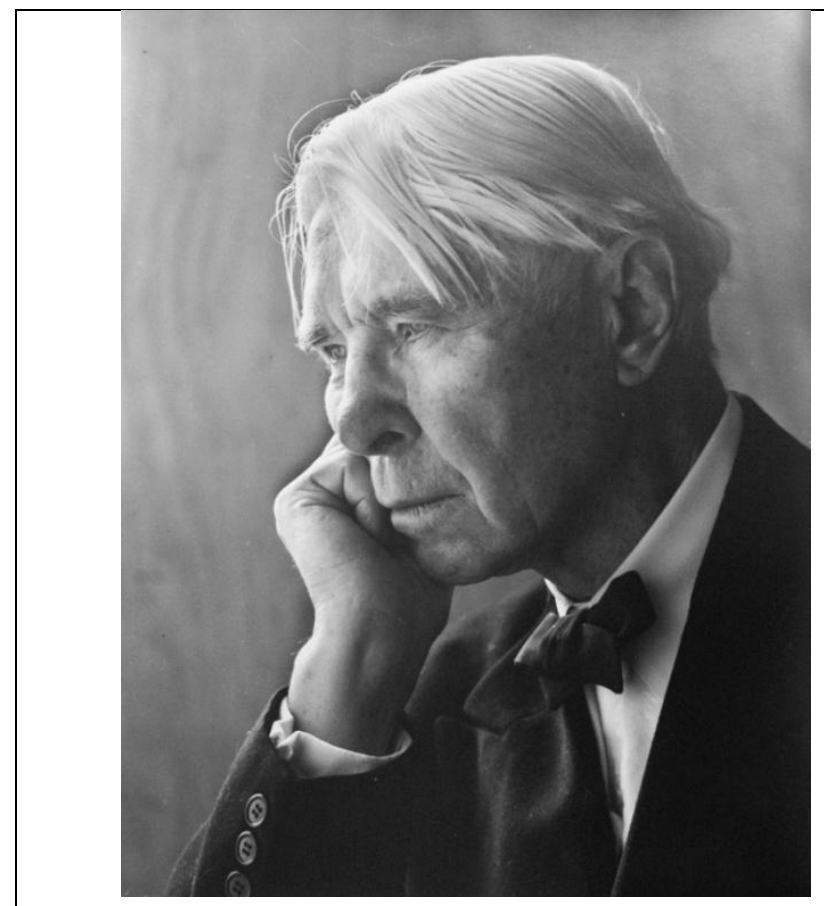

Figure 37

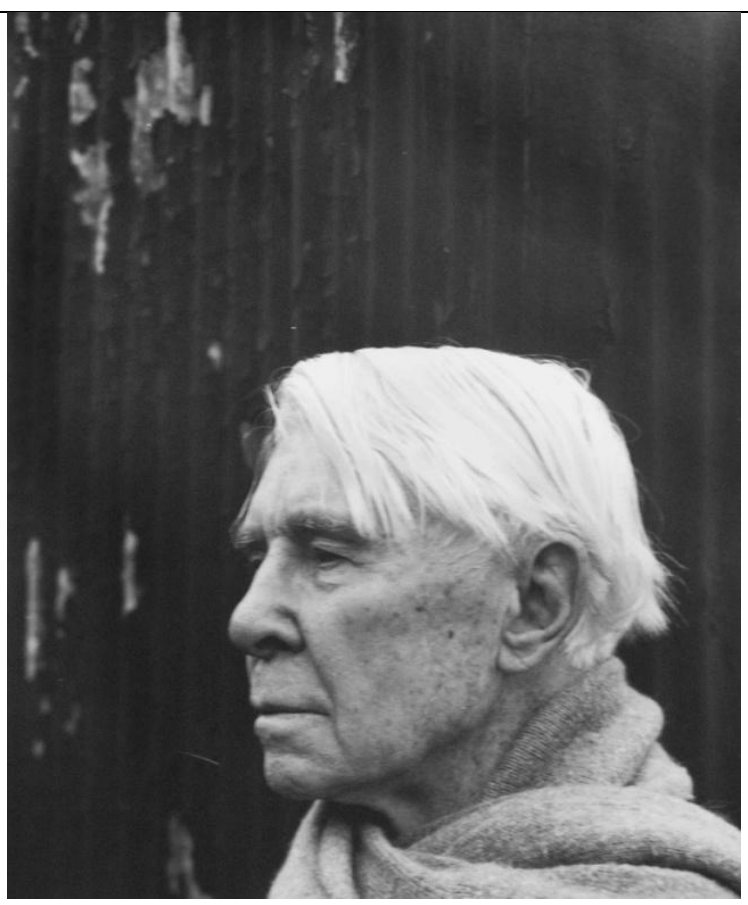

Figure 38

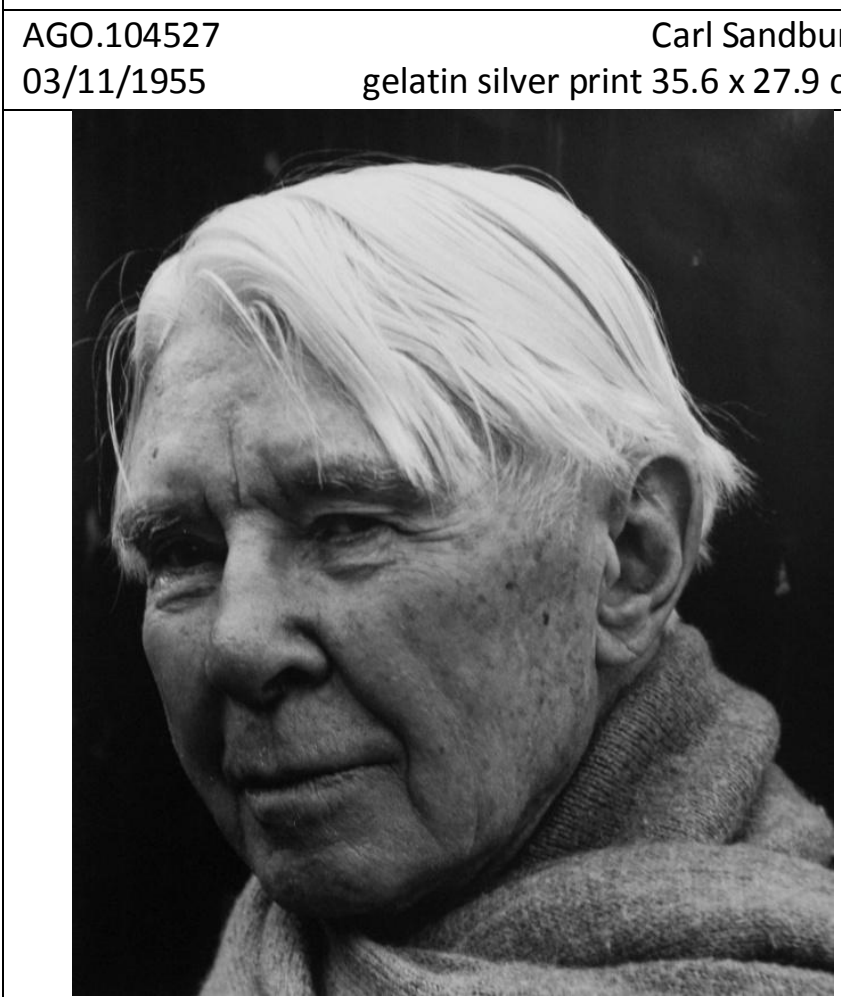

Figure 39
AGO.104528

03/11/1955
Carl Sandburg gelatin silver print $35.6 \times 27.9 \mathrm{~cm}$

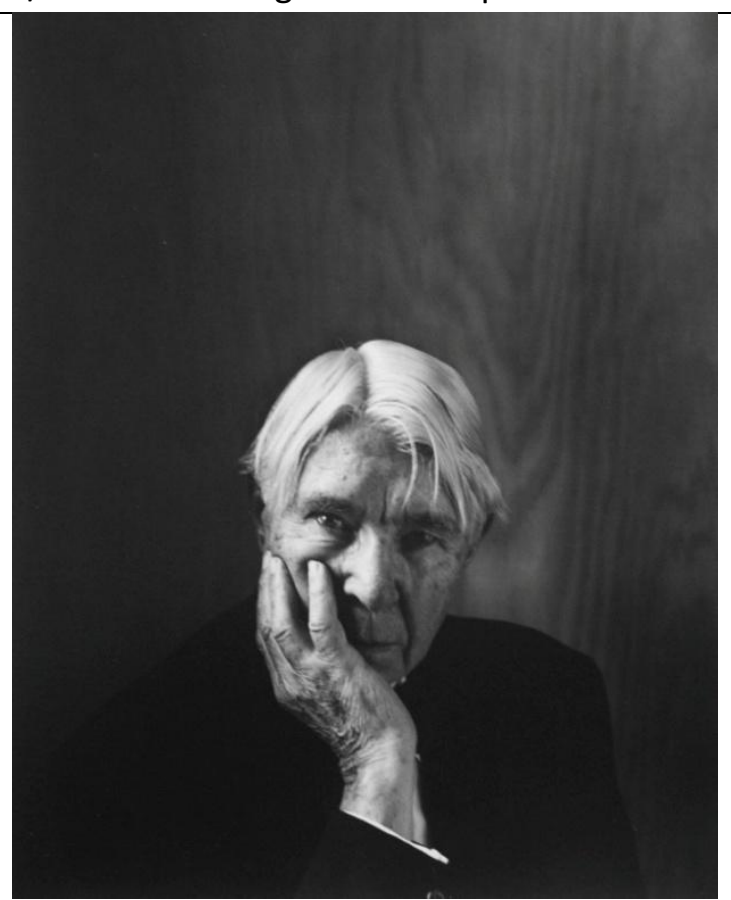

Figure 40 


\begin{tabular}{|c|c|}
\hline Mark(s) & Mark(s) \\
\hline Print number in pencil, verso BL: 833 & Print number in pencil, verso BL: 834 \\
\hline $\begin{array}{l}\text { Sitting book number in pencil, verso C and BR: \#2401- } \\
15\end{array}$ & $\begin{array}{l}\text { Sitting book number in pencil, verso C and BR: \#2401- } \\
34\end{array}$ \\
\hline Artist stamp in ink, verso C: C ARNOLD NEWMAN/THIS & Artist stamp in ink, verso C: (C) ARNOLD NEWMAN/THIS \\
\hline PHOTOGRAPH CANNOT BE COPIED/TELEVISED OR & PHOTOGRAPH CANNOT BE COPIED/TELEVISED OR \\
\hline REPRODUCED IN ANY FORM/WITHOUT THE & REPRODUCED IN ANY FORM/WITHOUT THE \\
\hline EXPRESSED AND WRITTEN/PERMISSION OF THE & EXPRESSED AND WRITTEN/PERMISSION OF THE \\
\hline PHOTOGRAPHER, IT/CAN BE USED FOR EXHIBIT & PHOTOGRAPHER, IT/CAN BE USED FOR EXHIBIT \\
\hline PURPOSES ONLY./39 WEST 67th ST. N.Y.C. 10023 & PURPOSES ONLY./39 WEST 67th ST. N.Y.C. 10023 \\
\hline Inscription(s) & Inscription(s) \\
\hline No inscriptions. & No inscriptions. \\
\hline Carl Sandburg & Carl Sandburg \\
\hline gelatin silver print $35.6 \times 27.9 \mathrm{~cm}$ & gelatin silver print $35.6 \times 27.9 \mathrm{~cm}$ \\
\hline $\begin{array}{l}\text { Mark(s) } \\
\text { Print number in pencil, verso BL: } 835\end{array}$ & $\begin{array}{l}\text { Mark(s) } \\
\text { Print number in pencil, verso BL: } 836\end{array}$ \\
\hline $\begin{array}{l}\text { Sitting book number in pencil, verso C and BR: \#2401- } \\
33\end{array}$ & Sitting book number in pencil, verso C and BR: 2401 \\
\hline Artist stamp in ink, verso C: (C) ARNOLD NEWMAN/THIS & $\begin{array}{l}\text { Artist stamp in ink, verso C: C ARNOLD NEWMAN/THIS } \\
\text { PHOTOGRAPH CANNOT BE COPIED/TELEVISED OR }\end{array}$ \\
\hline $\begin{array}{l}\text { PHOTOGRAPH CANNOT BE COPIED/TELEVISED OR } \\
\text { PHOT }\end{array}$ & REPRODUCED IN ANY FORM/WITHOUT THE \\
\hline REPRODUCED IN ANY FORM/WITHOUT THE & EXPRESSED AND WRITTEN/PERMISSION OF THE \\
\hline EXPRESSED AND WRITTEN/PERMISSION OF THE & PHOTOGRAPHER, IT/CAN BE USED FOR EXHIBIT \\
\hline PHOTOGRAPHER, IT/CAN BE USED FOR EXHIBIT & PURPOSES ONLY./39 WEST 67th ST. N.Y.C. 10023 \\
\hline PURPOSES ONLY./39 WEST 67th ST. N.Y.C. 10023 & Inccrintion/d) \\
\hline Inscription(s) & Inscribed in pencil, recto under image BL: Carl \\
\hline Inscribed in pencil, verso C: SS neg & Sandburg 1955 \\
\hline Inscribed in pencil, verso BL: OA 51823 & Inscribed in pencil, verso C: GAL \\
\hline Carl Sandburg & AGO.104530 \\
\hline gelatin silver print $35.6 \times 27.9 \mathrm{~cm}$ & gelatin silver print $35.6 \times 27.9 \mathrm{~cm}$ \\
\hline
\end{tabular}




\section{Graham, Martha (1894 - 1991) American Dancer and Choreographer}

The photographs below are all from a single studio session Newman conducted with Graham during the year 1961. There are twelve photographs of Graham during this studio session, and it represents one of the larger bodies of work surrounding a single sitting subject in the Newman Collection. The variants can be found in a wide variety of sizes in Box 23 . 


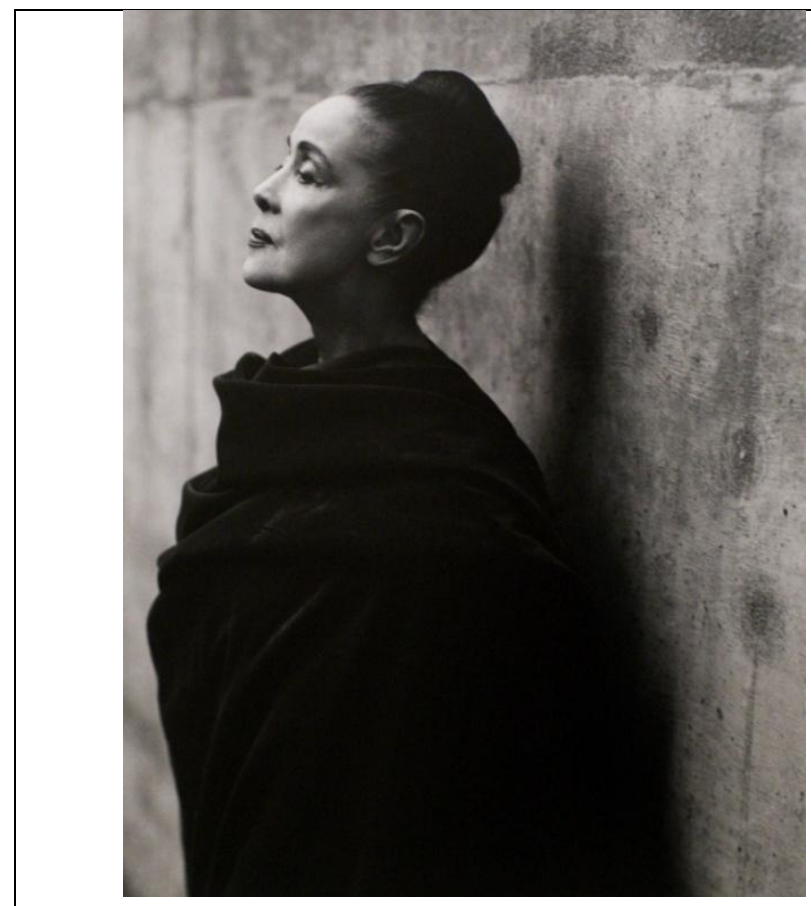

Figure 41

\section{AGO.107363} 02/03/1961

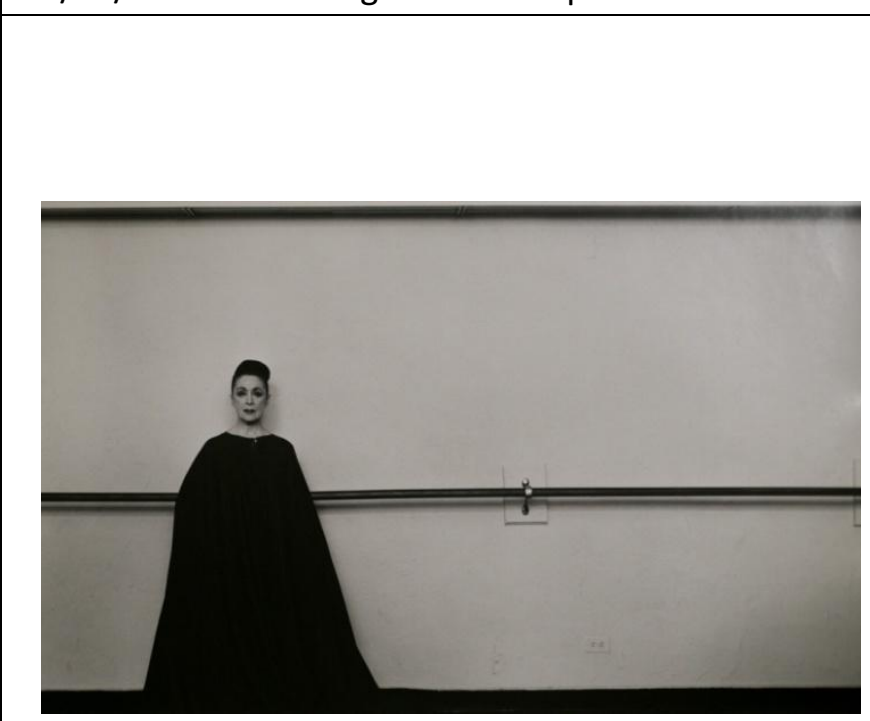

Figure 43
AGO.107411

02/03/1961
Martha Graham gelatin silver print $40.6 \times 50.8 \mathrm{~cm}$
AGO.107413

02/03/1961
Figure 42

AGO.107412

02/03/1961

Martha Graham gelatin silver print $50.8 \times 40.6 \mathrm{~cm}$

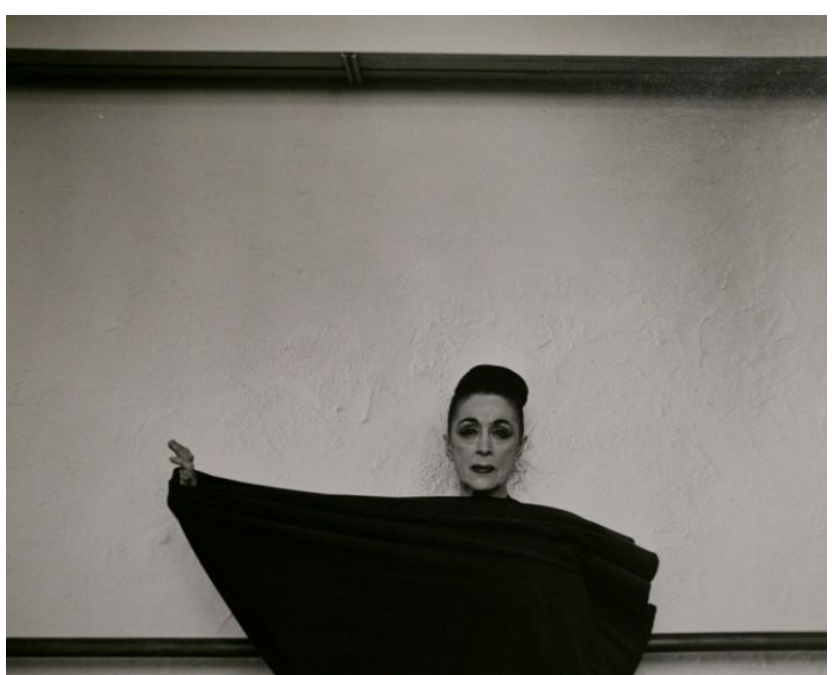

Figure 44 gelatin silver print $27.9 \times 35.6 \mathrm{~cm}$ 


\begin{tabular}{|c|c|}
\hline Mark(s) & Mark(s) \\
\hline Print number in pencil, verso BL: 4592 & Print number in pencil, verso BL: 4683 \\
\hline Sitting book number in pencil, verso TC: $418-49$ & Sitting book number in pencil, verso C: 4168 \\
\hline Artist stamp in ink, verso C: ARNOLD NEWMAN/39 & Artist stamp in ink, verso C: (C) ARNOLD NEWMAN/THIS \\
\hline WEST 67 STREET/NEW YORK 23, N. Y. & PHOTOGRAPH CANNOT BE COPIED/TELEVISED OR \\
\hline Artist stamp in ink, verso BR: C ARNOLD & REPRODUCED IN ANY FORM/WITHOUT THE \\
\hline NEWMAN/THIS PHOTOGRAPH CANNOT BE & EXPRESSED AND WRITTEN/PERMISSION OF THE \\
\hline FORM/WITHOUT THE EXPRESSED AND & PHOTOGRAPHER, IT/CAN BE USED FOR EXHIBIT \\
\hline $\begin{array}{l}\text { WRITTEN/PERMISSION OF THE PHOTOGRAPHER, } \\
\text { IT/CAN BE USED FOR EXHIBIT PURPOSES ONLY./39 }\end{array}$ & PURPOSES ONLY./33 WEST 67th ST. N.Y.C. 23, N.Y. \\
\hline WEST 67th ST., N.Y.C. 10023 & Inscription(s) \\
\hline Inscription(s) & Inscribed in pencil, verso BR: V16/001 \\
\hline Martha Graham & Martha Graham \\
\hline gelatin silver print $25.4 \times 20.3 \mathrm{~cm}$ & gelatin silver print $50.8 \times 40.6 \mathrm{~cm}$ \\
\hline Mark(s) & Mark(s) \\
\hline Print number in pencil, verso BL: 4712 & Print number in pencil, verso BL: 4639 \\
\hline Sitting booknumber in pencil, verso BR: $4168-8$ & Sitting booknumber in pencil, verso C: $4168-31$ \\
\hline Artist stamp in ink, verso BR: (C) ARNOLD & Artist stamp in ink, verso C: (C) ARNOLD NEWMAN/THIS \\
\hline NEWMAN/THIS PHOTOGRAPH CANNOT BE & PHOTOGRAPH CANNOT BE COPIED/TELEVISED OR \\
\hline COPIED/TELEVISED OR REPRODUCED IN ANY & REPRODUCED IN ANY FORM/WITHOUT THE \\
\hline FORM/WITHOUT THE EXPRESSED AND & EXPRESSED AND WRITTEN/PERMISSION OF THE \\
\hline WRITTEN/PERMISSION OF THE PHOTOGRAPHER, & PHOTOGRAPHER, IT/CAN BE USED FOR EXHIBIT \\
\hline IT/CAN BE USED FOR EXHIBIT PURPOSES ONLY./39 & PURPOSES ONLY./39 WEST 67th ST. N.Y.C. 10023 \\
\hline WEST 67th ST. N.Y.C. 10023 & Inscription(s) \\
\hline Inscription(s) & Inscribed in pencil, recto under image BL: V11/014 \\
\hline Inscribed in pencil, recto under image BR: V18/002 & \\
\hline Martha Graham & AGO.107413 \\
\hline gelatin silver print $40.6 \times 50.8 \mathrm{~cm}$ & gelatin silver print $27.9 \times 35.6 \mathrm{~cm}$ \\
\hline
\end{tabular}




\section{Annotated Bibliography:}

\section{Masterclass: Arnold Newman}

Newman, Arnold, William A. Ewing, Todd Brandow, Arthur Ollman, David Coleman, Corinne Currat, and Arnold Newman. Masterclass: Arnold Newman. London: Thames \& Hudson, 2012.

Masterclass is a recent publication of Newman's work, coinciding with an exhibition curated by William A. Ewing. The book contains a preface by curator Todd Brandow, and essays by Ewing, photographer Arthur Ollman, David Coleman and biographies by curator Corinne Currat. Each essay approaches Newman from a different perspective; Ewing investigates Newman's history by breaking up his photographic career into two parts, named Student and Master. Student covers Newman's formative years and investigates the figures, events and institutions that would influence his early photographic practice. Master focuses on his years as a practicing photographer. Ollman approaches Newman from a personal perspective. Finally, Coleman investigates Newman's work with Great American Faces, which is more thoroughly covered by the publication Faces USA. Masterclass contains many plates found in both colour and black and white. For researchers investigating Arnold Newman, his history, his publications or his exhibitions, Masterclass is an effective overview of his photographic career.

\section{Visions and Images}

Diamonstein-Spielvogel, Barbaralee, and Harry M. Callahan. Visions and Images, American Photographers on Photography. New York: Rizzoli, 1981.

Visions and Images contains a number of printed interviews conducted by the author, Diamonstein-Spielvogel, a prominent American public servant, with a number of American photographers. Each interview revolves around the photographer's work, history and thoughts on the state of contemporary photography.

Diamonstein-Spielvogel's interview with Arnold Newman investigates his portraits, his growth as a photographer and his thoughts on the future of his practice. They specifically mention such subjects 
as Piet Mondrian, John Kennedy, Alfried Krupp, Pablo Picasso, Igor Stravinsky and Jackson Pollock. Newman describes how he worked with each of these subjects, how the session progressed and the reception of each portrait. In this interview he also discusses his relationship with his wife, Augusta Newman, and how her efforts and contributions to his photographic practice make it possible for him to dedicate himself to the act of taking a photograph.

\section{Interviews with Master Photographers}

Danziger, James, and Barnaby Conrad. Interviews with Master Photographers. New York: Paddington, 1977.

James Danziger, an American gallerist and Barnaby Conrad III, an American author and artist, engage with and interview a number of photographers they deem to be "masters" of photography. Within Interviews the authors engage with Minor White, Imogen Cunningham, Cornell Capa, Elliott Erwitt, Yousuf Karsh, Arnold Newman, Lord Snowdon and Brett Weston.

The interview with Arnold Newman was conducted by both Danziger and Conrad and took place within the Newman family home as well as Newman's photographic studio. Questions about Newman's past and present photographic practice, Newman's thoughts on the state of contemporary photography and his preferences regarding camera technology arise in the discussion. The largest topic of conversation revolves around the act of taking a portrait, and the strategies Newman employs in taking what he considers to be a great photograph. The responses are thorough and give many insights into Newman's photographic practice and work, outside of the art historical interpretations of his work found throughout his major publications and photographic books. Those who are interested in Newman as a research subject would benefit from reading this interview. The book contains two black and white reproductions of photographs taken by Arnold Newman, Alfried Krupp, Essen, Germany 1963 and Claes Oldenburg, 1967-1972. Both of these photographs can be found within the Arnold Newman Collection of Photographs. 


\section{Arnold Newman: Five Decades}

Ollman, Arthur, and Arnold Newman. Arnold Newman: Five Decades. San Diego: Harcourt Brace Jovanovich Publ., 1986.

Five Decades is a photographic book containing 114 black and white reproductions of portraits taken by Arnold Newman between the years 1938 and the year of publication, 1986. Each photograph takes up a full page, with basic caption information (i.e. "68 LOUISE NEVELSON, NEW YORK CITY, 1972"). Arthur Ollman, an American photographer, introduces the book and succinctly covers Arnold Newman's photographic practice from its inception to the date of publication. He investigates many individual photographs illustrated in the book, while giving insights into the defining characteristics of Newman's practice during each decade. Following this introduction is a detailed biography covering Newman's academic, professional and artistic career. The book ends with a short afterword by Newman in which he outlines his thoughts on developing style, his own photographic practice, what photography is capable of achieving and what he hopes to accomplish with this retrospective. The essays can be reviewed in a short period of time. The book offers a selection of images that Newman considers important to his practice from the years $1938-1986$. Finally, the index of sitting subjects within this publication makes it easy to find corresponding sitting subjects from this publication which are also represented in the Newman Collection at the AGO.

\section{Artists, Portraits from Four Decades}

Newman, Arnold and Henry Geldzahler. Artists, Portraits from Four Decades. Boston: New York Graphic Society, 1980.

Artists, Portraits from Four Decades is a photographic publication with a foreword by Henry Geldzahler, commissioner of cultural affairs for New York City, and includes an introduction by Arnold Newman. While Four Decades strives to understand Newman's overall practice as a photographer, Artists specifically informs the reader of Newman's photographic approach to framing and taking portraits of other artists. As such, the essay sets a tone that delves into art history and art theory. 
Considering the potential future uses of the Arnold Newman Collection of Photographs within the context of the Art Gallery of Ontario, it makes sense that the photographs of artists will be in high demand. Anticipating this, Artists is an important publication to consider for anyone investigating Arnold Newman as an artist, or investigating the Newman Collection of Photographs within the larger context of an art gallery. Finally, the index of sitting subjects allows for the cross reference of those subjects represented in the Arnold Newman Collection of Photographs.

\section{Arnold Newman, Photo District News by Anthony Lasala}

Lasala, Anthony. "Arnold Newman." Photo District News [New York City] Aug. 1998, 18th ed., sec. 8.

Lasala's interview is directed towards Newman's early photographic career and Newman's thoughts on environmental portraiture. This interview does have some information not contained in other interviews in the annotated bibliography. However, Interviews with Master Photographers is far more thorough.

\section{One Mind's Eye: The Portraits and Other Photographs of Arnold Newman}

Newman, Arnold, and Robert Sobieszek. One Mind's Eye: The Portraits and Other Photographs of Arnold Newman. Boston:

D. R. Godine, 1974.

Out of all the publications listed in this bibliography, One Mind's Eye presents the reader with the widest variety of styles that can be found within Arnold Newman's photographic career. All the plates (192 in total) are presented with an additional seven pages of drawings, contact prints and photographic variants. These additional images are included alongside an introduction by Robert Sobieszek, curator of George Eastman House in Rochester, N.Y. By taking quotes from Newman and using photographic source material as an effective visual aid, Sobieszek constructs one of the most informative and thorough biographies on the artist. Paired with the extensive collection of photographs, One Mind's Eye becomes a relevant publication for anyone researching Newman in any form. Finally, 
the included index of sitting subjects within this publication make it easy to cross reference sitting subjects from this publication with those that are also represented in the Arnold Newman Collection of Photographs.

\section{Artists Look Like This}

Archives of American Art. "Artists Look Like This." Archives of American Art: The Quarterly Bulletin 2.4, 3.1, 3.2, 3.3, 3.4.

1962-1963

Artists Look Like This was published through the Archives of American Art. It is composed of a singular photograph with a small caption underneath. Five photographs of artists taken by Arnold Newman were published, in order: Jacques Lipschitz, David Hare, Jo Davidson, Frederico Castellon and Karl Knaths. Each photograph has a very short biography (approximately 100 words) about the represented artist. Unless the reader is interested in Newman's photographs as mass produced objects, or is particularly interested in the Archives of American Art, I would not recommend investigating these prints in much depth.

\section{Bravo Stravinsky}

Newman, Arnold, Robert Craft, Francis Steegmuller, and Igor Stravinsky. Bravo Stravinsky. Cleveland: World Pub., 1967.

The content in Bravo Stravinsky investigates Russian born composer Igor Stravinsky`s daily life in 1966. A foreword by Francis Steegmuller introduces the publication and gives some insights into Stravinsky, his thoughts and his lasting legacy. Stravinsky's relationship with Arnold Newman goes back to the beginning of Newman's career; one of Newman's most recognized and popular photographs is a portrait of Stravinsky sitting at his grand piano.

The rest of the publication consists of photographs taken by Arnold Newman alongside an essay by Robert Craft. The arrangement of the text and photographs is very reminiscent of the popularized mid $19^{\text {th }}$-century photo-essay, with the text being secondary to the multitude of photographs that take up 
the majority of the page space. Unlike the other publications covered in this annotated bibliography, Bravo Stravinsky highlights Newman's ability to put together a body of work around a single topic, constructing a full and well thought out narrative. Bravo Stravinsky is an important publication for researchers interested in the Arnold Newman Collection of Photographs. In the collection, there is a full book dummy containing all of the original prints used for the publication of this book.

\section{Arnold Newman in Florida}

Newman, Arnold, Richard A. Madigan and Bruce Weber. Arnold Newman in Florida. Boston, MA: D.R. Godine in Association with Norton Gallery of Art, 1988.

Arnold Newman in Florida is an exhibition catalogue organized by curator Bruce Weber of the Norton Gallery of Art in West Palm Beach, Florida. The book focuses on Newman's photographic production that took place while he was living in West Palm Beach, Florida at the beginning of his career. The exhibition includes a group of prints Newman would produce revisiting Florida in the 1980’s.

The publication has a brief introduction by Richard A. Madigan, director of the Norton Gallery of Art, and is followed by an interview held between Newman and Weber. Researchers will find this interview valuable as it focuses on a very specific time in Newman's career. Newman enlightens the reader on his years spent in high school, the few years he spent studying in university and how photographing West Palm Beach would inform his future photographic practice. Weber and Newman discuss early exhibitions, his move to New York City in the 40s, his return to Miami and Newman's first portrait studio. The interview is detailed, thorough and provides some of the best material on Newman's formative years as a practicing photographer. The remainder of the publication consists of black and white photographs, arranged singularly on a page with basic identifying information underneath. The publication ends with an exhibition checklist. 


\section{Photographers Photographed}

Jay, Bill. Photographers Photographed. Salt Lake City: Peregrine Smith, 1983.

Photographers Photographed is a compilation of photographs taken by English photographer Bill Jay, of other photographers. Each photograph is accompanied by a short written caption detailing some of Jay's thoughts on the photograph and/or the photographer. Newman's likeness can be found on page 13, where he is seated in his New York City apartment. While the publication does not go into much detail about Newman, it may be a worthwhile publication to investigate if one is interested in photographs of artists or photographs, or representations of Newman made by a contemporary.

\section{On the Other Side of the Camera}

Crane, Arnold H. On the Other Side of the Camera. Köln: Könemann, 1995.

On the Other Side of the Camera is a publication of photographs taken by American photographer Arnold Crane of other photographers. The chapters contain four to six photographs of each photographer in a variety of settings alongside a brief written essay on the photographers in English German and French. Crane's photographs of Newman were taken in his New York Studio in 1995. Newman is seen at his desk working, sitting on a chair in the middle of his studio and the final photograph is a traditional headshot with a dark background. The essay on Newman is a general overview of his photographic career and does not offer any additional information than what can be found in any of the publications dedicated solely to Newman.

\section{Celebrating the Negative}

Loengard, John. Celebrating the Negative. New York: Arcade Pub., 1994.

Celebrating the Negative is a photographic publication created by LIFE magazine photographer John Loengard. Within, Loengard displays photographs of negatives while they are being held by the original photographer. These negatives are held in front of a light source to better illu minate the finer 
details of the object. A summary of the historical importance of the negative is provided alongside each photograph.

On page 59 of the publication, Newman's negative of Igor Stravinsky is shown, with Newman holding it with white cotton gloves. Leongard provides context for the reader, labelling it as one of Newman's seminal photographs. Researchers will find this source useful if they are interested in representations of Newman and his photographic career.

\section{Famous Portraits}

Gruber, L. Fritz. Famous Portraits. New York: Ziff-Davis Pub., 1960.

Edited by L. Fritz Gruber, a prominent collector of photographs, Famous Portraits is a selection of what the editor considers to be particularly well known examples of photographic portraiture from the mid- $20^{\text {th }}$ century. The editor has assembled 120 plates, five of which are taken by photographer Arnold Newman. Near the end of the publication are summaries that are about the sitting subject or the history of the photographs and the photographer. The represented Newman Photographs are as follows:

\#7 Dr. J. Robert Oppenheimer; \#31 Igor Feodorovitsch Stravinsky; \#83 Alexander Calder; \#93 Georgia O’Keeffe and Alfred Stieglitz and \#95 Piet Mondrian.

\section{Photography in the Twentieth Century}

Lyons, Nathan, Jean Sutherland, James Boggs, and Beaumont Newhall. Photography in the Twentieth Century. New York: Horizon Press in collaboration with the George Eastman House, Rochester, N.Y., 1967.

Organized by Nathan Lyons, former curator of George Eastman House, Photography in the Twentieth Century is a book containing photographs shown by the institution under an exhibition with the same name. Lyons gives a general introduction followed by 143 photographic plates. Newman's photograph of Max Ernst was included in the exhibition and it can be found on page 39 . 


\section{The Contact Sheet}

Crist, Steve. The Contact Sheet. Los Angeles, California: AMMO, 2009.

The Contact Sheet offers the reader an interesting investigation into a photographic practice that other publications in this bibliography fail to do, by comparing and contrasting a single image alongside its original contact sheet. Within, Crist covers Newman's work with Charles and Ray Eames, furniture designers. To the right of the image summary are four negatives with the final image on the following page. This is an important publication as it is one of the few included in this bibliography that compares and contrasts a finalized image with a number of unedited variants.

\section{Great Photographers}

Great Photographers. New York, NY: Time-Life, 1971. Print.

Great Photographers acts as a survey of what the editor of Time-Life considers to be the world's greatest photographs throughout history. Each section is broken down by two to four decades represented by approximately a dozen photographers. Each photographer is represented by a summary alongside two to four images. Arnold Newman is found on page 228-229 and is represented by his photographs of Alfred Stieglitz and Geogia O'Keeffe and Yaacov Agam. The summary is brief and contains no information that cannot be found in one of the publications dedicated solely to Newman's work. If researchers are interested in how Newman has been appropriated into publications concerned with the general history of photography, this may be a worthwhile source to investigate.

\section{The Photographer's Eye}

Szarkowski, John. The Photographer's Eye. New York: Museum of Modern Art; Distributed by Doubleday, Garden City, N.Y., 1966. Print.

Based on an exhibition by the same name, organized by famed Museum of Modern Art, New York City, N.Y., curator John Szarkowski, the publication acts as a reinvestigation into the formal ways photographs are perceived. Newman's photograph of Jean Arp can be found in the top right corner of page 86. For those researchers interested in Newman's presence in major photographic exhibitions of the 
$20^{\text {th }}$ century, and the specific analysis of these photographs by Szarkowski, The Photographer's Eye will be of importance.

\section{Looking at Photographs}

Szarkowski, John. Looking at Photographs; 100 Pictures from the Collection of the Museum of Modern Art. New York: Distributed by New York Graphic Society, Greenwich, Conn, 1973.

Edited by Museum of Modern Art (MOMA) curator John Szarkowski, Looking at Photographs fulfills the dual purposes of showcasing the MOMA's large collection of photographs and acting as an investigation into the changing landscape of photographic practice during the MOMA's then 40 years of collecting. Unrepresented are colour photographs, as Szarkowski believes they deserve their own anthology. Looking at Photographs provides interpretive text to assist in an understanding of the medium. Each photographer has two pages dedicated to their work, with one page containing a brief biography next to a photograph held at MOMA. Arnold Newman's section can be found on page 140, next to a photograph of Yasuo Kuniyoshi with a worthy analysis by Szarkowski. For researchers interested in how Newman's work is represented within the context of a greater photographic and art collection, or Szarkowski's interpretations of Newman's work, this is a worthwhile publication to investigate.

\section{Exploring Photography}

Campbell, Bryn. Exploring Photography. New York: Hudson Hills, 1979.

Exploring Photography is a survey publication with 100 images which focuses on investigating the myriad of methods photographers employ in the creation of their photographs. Author and historian Bryn Campbell investigates two of Newman's photographs which are often overlooked, his collages of Andy Warhol and Clays Oldenburg, which was deliberately torn halfway down the middle. These photographs can be found on page 129. Newman gives insight on the decisions he made creating these two photographs, and his thoughts on physically manipulating the photographic paper for each print. 


\section{The Picture History of Photography.}

Pollack, Peter. The Picture History of Photography: From the Earliest Beginnings to the Present Day. New York: H.N. Abrams, 1969.

The Picture History of Photography is a large publication, over 700 pages in length containing hundreds of photographic plates. Acting as a survey for the entire history of photography, American curator Peter Pollack investigates photography and photographers from its inception up until 1969, the date of this edition's revision. Chapter 50, under the section Photography Today, is dedicated to Arnold Newman. While the chapter on Newman is short, it is of use to researchers investigating his role within a larger context of photographic history.

\section{Arnold Newman, The Early Work}

Newman, Arnold, Ron Kurtz, Howard Greenberg, and Philip Brookman. Arnold Newman: The Early Work. Göttingen: Steidl, 2008.

The Early Work is a posthumous publication centering around Newman's photographic practice before he would become a professional photographer. The imagines found in the book focus on the years of 1938 - 1941, the year he was "discovered” by Beaumont Newhall and Alfred Stieglitz.

There are two forewords written by Ron Kurtz, and Howard Greenburg, who both new Newman personally and professionally. An introduction by Philip Brookman introduces the reader both to Newman, and the purpose of the publication. Newman's formative years as a photographer were not focused on portraiture specifically; however, Newman considered the work he made in West Palm Beach to be of great importance to the development of his career as a portrait photographer. The work is arranged chronologically, and each two page spread contains a single photograph on the right, with the name and date of the photograph on the left. There is no afterword or list of plates, however the publication has approximately 100 photographs. 


\section{The Great British}

Newman, Arnold, John Hayes, The Great British. Boston: New York Graphic Society, 1979.

The Great British is an exhibition publication detailing a project put together between John Hayes, director of the National Portrait Gallery and Arnold Newman; where he was to photograph prominent British figures so their likeness could be held at the new photographic collection at the National Portrait Gallery. The introduction by George Perry covers the inception of the project and their choice in employing Arnold Newman. Perry further covers Newman's shooting style, and the variety of strategies Newman employs when easing a new subject into having their portrait taken. Finally, biographical information provides context for Newman as a person and a photographer. The publication is informative as each plate has a biography of the sitting subject alongside anecdotes provided by Newman. There are a large number of colour photographs in this collection, which is differentiates the publication from most Newman publications which only contain black and white images.

\section{Faces USA}

Newman, Arnold. Faces USA. Garden City, NY: American Photographic Book Pub., 1978.

Faces USA is a publication covering a project named Great American Faces involving Arnold Newman and a number of American art institutions, in which Newman was challenged to take portraits of American citizens and families chosen by a panel of judges for the contest. Great American Faces was a much larger project outside of Newman's contributions, as it also included thousands of snapshots sent in by families from across the nation to be selected by judges for exhibition. This publication in particular only shows Newman's work—each family that he took portraits of includes a brief introduction alongside a number of black and white photographs. 


\section{Natural Beauty: Farber Nudes}

Farber, Robert. Natural Beauty: Farber Nudes. London: Merrell, 2001.

Natural Beauty, as the source would indicate, is not a Newman publication—instead it contains a brief foreword written by Newman on Farber's photographic practice and the act of taking portraits of nudes.

\section{El Regalo De Newman, 50 Anos de Fotografia}

Fundacion Pedro Barrie De LaMaza, Conde DeFenosa, ed. ElRegaloDe Newman 50 Anos DeFotografia. Coruna: Tapa Blanda, 1998.

A Spanish exhibition catalogue showcasing Newman's work spanning his 50 year career. This would be beneficial for those researchers interested in how Newman's photographs have been exhibited outside of the North American art sphere.

\section{Newman's Own}

Ben-David, Calaev. The Jerusalem Report (Feb 24, 1994): 42.

This article published in The Jerusalem Report by reporter Calaev Ben-David who discusses Newman's relationship to Israel via Newman's wife, and the portraits the photographer has taken of prominent members of the Israeli Community. Newman's photographic career would include many trips to Israel to capture the portraits of politicians, artists and prominent members of the Israeli community. The article is interesting in that it analyzes a very small portion of Newman's artistic output based on geography. Further, it is one of the few articles that mentions Newman's wife, how they met and her role within his photographic practice as record keeper and artistic advisor. The article discusses three photographs in particular, an image of Newman in Jerusalem, a photograph of David-Ben Gurion and a photograph of Piet Mondrian. 


\section{Everyone who was anyone: Arnold Newman photographed the heroes of the 20th century, from Truman to Marilyn Monroe. \\ Morgan-Griffiths, Lauris. Financial Times [London Edition (UK)] 11 Nov 2000: 08. Print}

This short article gives the reader a brief overview of Arnold Newman, and some of the portraits he has taken over the course of his career. Reporter Morgan-Griffiths shares a number of quotes by Arnold Newman to reinforce his narrative. Some of the photographs discussed are images of Marilyn Monroe, Igor Stravinsky, I.M. Pei and Picasso. For information on photographs of these subjects that are contained in the Arnold Newman Collection of photography, see the sitting subject index.

\section{Additional Sources}

\section{Techniques of the Masters}

Eastman Kodak Corporation "Techniques of the Masters.Arnold Newman and Andreas Heumann." Kodak Business Television. KBTV. Rochester, New York, 1990.

Techniques of the Masters is a two hour television broadcast was produced by the Eastman Kodak Company. The series includes a variety of talk-show and news style programs covering a wide variety of topics and events related to the world of photography. Each segment covers new photographic exhibitions, investigates new camera technologies, conducts interviews with photographers and curators and reviews photographic techniques for the aspiring photographer. Many of these topics are Eastman Kodak related. The lengthy interviews with master photographers provide an inside look into the life of a photographer on assignment. The final segment of this broadcast is dedicated to Arnold Newman. The program follows Newman as he conducts a studio session, creating a portrait for one member of the Kodak video production team.

Throughout the session, Newman provides insight into how he constructs an image. This includes his use of natural light, using props from the location to create a pleasing composition and how he has learned to effectively direct a sitting subject. Newman's team of photographic assistants are seen 
quite often and Newman himself comments on their technical abilities and their knowledge of when to "stay away so that I can build a relationship with my subject." Newman expands his thoughts and opinion to address the profession of photography in a more general fashion. The difficulty of the profession is a topic he believes is often overlooked by the general population.

The idea behind "environmental portraiture" is discussed, and Newman explains that he coined the term at the time because he was not aware of any photographers creating portraits in a similar style. Creating the term would allow people to easily discuss his photographs. He goes on to further talk about how he makes his subjects feel comfortable with having their picture taken, as it is unnatural to hold the same pose for four to five minutes. The broadcast continues in Newman's personal studio, which includes discussions on his filing and photographic storage system. Newman discusses his photographs of Nixon, Picasso and the difficulties of retaking Stravinsky's portrait after many years. The video is an effective resource as it allows the viewer to witness Newman's process in creating a portrait alongside personal commentary from the photographer himself.

\section{Interview: Photographer Arnold Newman Discusses his Photography and his Book, Arnold Newman}

Morning Edition: 1. Washington, D.C.: National Public Radio. 2000. Radio Broadcast

Interview was conducted by National Public Radio's Renee Montange who covers Newman's publication Arnold Newman. The two discuss Newman's interactions with his subjects when taking a

portrait; specifically they cover his photographs of Gypsee Rose Lee, Igor Stavinsky, Woody Allen and Alfried Krupp. For the Krupp session, Newman specifically elaborated on his printing technique, the emanation of the green tone cast, and his subjective choices in printing the photograph in this colour. 


\section{Contents}

The main body of work within the Arnold Newman Collection of Photographs are portraits taken of approximately 1,300 different sitting subjects. There are also some, albeit relatively few, photographs of landscapes and abstract photographs. Many of these photographs have been separated out of the portraits for ease of browsing based on their title. Newman would often title his photographs as abstracts or landscapes.

Of the sitting subjects, many have been successfully identified; however, there are still approximately 300 subjects that have yet to be identified or could not be identified with the information available at this time. Unidentified subjects are labelled as such if the writer could not find any pertinent information, or if there was not enough identifying information (i.e. AGO.104802 - Graham).

This finding aid contains two main sections to assist in finding particular portraits. A list of identified sitters, listed alphabetically which include life dates, nationality and recognized occupation. To the right of this information one will find the number of photographic prints associated with this subject, the dates these photographs were taken, and the box(es) within which one can find these photographs. ID numbers have not been provided as they vary widely. One can find AGO ID numbers in the electronic spreadsheet box lists provided with this finding aid.

The section containing unidentified sitters has been organized in a similar manner, minus life dates, nationality and occupation. If a researcher does happen to successfully identify an unknown sitter, the writer requests that AGO collections management staff is made aware so that this finding aid may be updated in the future. The following pages of this finding aid will list, at approximately 45 entries per page, each subject and where their related photograph can be found. An additional five pages will be dedicated to unidentified sitters. 


\section{Sitting Subject Index}

\begin{tabular}{|c|c|c|c|c|}
\hline Name (Birth - Death) & Nationality / Occupation & \# & Neg. Date & $\begin{array}{l}\text { General } \\
\text { Location }\end{array}$ \\
\hline Abbado, Claudio (1933) & Italian Conductor & 2 & $02 / 05 / 1983$ & Box 1 \\
\hline Abbot, Berenice (1898 - 1991) & American Photographer & $\begin{array}{l}1 \\
2\end{array}$ & $\begin{array}{l}04 / 09 / 1944 \\
13 / 01 / 1986\end{array}$ & Box 1 \\
\hline Abbott, Charles (1872 - 1973) & American Astrophysicist & 1 & $16 / 04 / 1965$ & Box 15 \\
\hline Abramov, Ayala Zacks (1912 - 2011) & Israeli-Canadian Art Collector & 1 & $02 / 06 / 1982$ & Box 1 \\
\hline Abrams, Harry (Unknown) & American Businessman & 1 & $30 / 04 / 1970$ & Box 1 \\
\hline Acheson, Dean (1893 - 1971) & American Secretary of State & $\begin{array}{l}3 \\
2\end{array}$ & $\begin{array}{l}01 / 02 / 1949 \\
18 / 05 / 1966\end{array}$ & Box 1 \\
\hline Adams, Ansel (1902 - 1984) & American Photographer & $\begin{array}{l}2 \\
3\end{array}$ & $\begin{array}{l}12 / 06 / 1975 \\
07 / 08 / 1976\end{array}$ & Box 1 \\
\hline Adams, Robert (1937) & American Photographer & 1 & $05 / 09 / 1974$ & Box 1 \\
\hline Adenhauer, Konrad (1949 - 1963) & German Politician & 3 & $01 / 03 / 1954$ & Box 1 \\
\hline Adler, Allen (1916 - 1964) & American Writer & 1 & $20 / 08 / 1975$ & Box 18 \\
\hline Adler, Julius Ochs (1892 - 1955) & $\begin{array}{l}\text { American Military Officer, Journalist } \\
\text { and Publisher }\end{array}$ & 2 & $29 / 10 / 1952$ & Box 1 \\
\hline Agam, Yaacov (1928) & Israeli Painter and Printmaker & 3 & $02 / 07 / 1966$ & $\begin{array}{l}\text { Box } 1 \\
\text { Box } 73\end{array}$ \\
\hline Albers, Anni (1899 - 1994) & German-American Textile Artist & $\begin{array}{l}2 \\
4\end{array}$ & $\begin{array}{l}04 / 09 / 1972 \\
26 / 05 / 1975\end{array}$ & $\begin{array}{l}\text { Box } 1 \\
\text { Box } 73\end{array}$ \\
\hline Albers, Josef (1988 - 1976) & German-American Painter, Theorist & $\begin{array}{l}2 \\
1 \\
1 \\
3 \\
3 \\
1\end{array}$ & $\begin{array}{l}06 / 05 / 1948 \\
09 / 06 / 1948 \\
01 / 05 / 1951 \\
01 / 01 / 1952 \\
04 / 09 / 1972 \\
26 / 07 / 1975\end{array}$ & $\begin{array}{l}\text { Box } 1 \\
\text { Box } 73\end{array}$ \\
\hline Albright, Ivan (1897 - 1983) & American Painter & 5 & $01 / 07 / 1952$ & $\begin{array}{l}\text { Box } 2 \\
\text { Box } 81\end{array}$ \\
\hline Alexander, Shana (1925 - 2005) & American Journalist & 1 & $19 / 03 / 1970$ & Box 2 \\
\hline Allen, Woody (1935) & American Film Director & 5 & $07 / 11 / 1946$ & Box 2 \\
\hline Allison, Bobby (1937) & American NASCAR Driver & $\begin{array}{l}1 \\
1\end{array}$ & $\begin{array}{l}23 / 01 / 1986 \\
24 / 01 / 1986\end{array}$ & Box 2 \\
\hline Allyson, June (1917 - 2006) & American Actress & 1 & $6 / 15 / 1948$ & Box 2 \\
\hline Anderson, Carl David (1905 - 1991) & American Physicist & 1 & $07 / 06 / 1948$ & Box 2 \\
\hline Anuszkiewicz, Richard (1930) & $\begin{array}{l}\text { American Painter, Printmaker and } \\
\text { Sculptor }\end{array}$ & $\begin{array}{l}3 \\
3\end{array}$ & $\begin{array}{l}28 / 03 / 1970 \\
09 / 05 / 1974\end{array}$ & Box 2 \\
\hline Appel, Karl (1921 - 2006) & Dutch Painter and Sculptor & $\begin{array}{l}5 \\
4\end{array}$ & $\begin{array}{l}12 / 05 / 1954 \\
22 / 04 / 1963\end{array}$ & Box 2 \\
\hline Arafat, Yasser (1929 - 2004) & Israeli President & 2 & $09 / 12 / 1993$ & Box 2 \\
\hline Aranguren, Luis (1909 - 1996) & Spanish Philosopher & 1 & $11 / 12 / 1964$ & Box 2 \\
\hline Araskog, Rand (1931) & American Businessman & 1 & 03/03/1981 & Box 2 \\
\hline Arman, Fernandez (1928 - 2005) & French Painter and Artist & 5 & $18 / 05 / 1977$ & Box 2 \\
\hline Armitage, Kenneth (1916 - 2002) & British Sculptor & 3 & $23 / 06 / 1966$ & Box 3 \\
\hline Arnold, Eddy (1918 - 2008) & American Singer & 2 & $08 / 08 / 1949$ & Box 3 \\
\hline Arp, Jean $(1886-1966)$ & $\begin{array}{l}\text { French Sculptor, Painter and } \\
\text { Collagist }\end{array}$ & 3 & $03 / 01 / 1949$ & $\begin{array}{l}\text { Box } 3 \\
\text { Box } 82\end{array}$ \\
\hline
\end{tabular}




\begin{tabular}{|c|c|c|c|c|}
\hline Arrau, Claudio (1903 - 1991) & Chilean-American Pianist & $\begin{array}{l}5 \\
3 \\
1\end{array}$ & $\begin{array}{l}01 / 01 / 1948 \\
24 / 11 / 1954 \\
18 / 10 / 1961\end{array}$ & Box 3 \\
\hline Artschwager, Richard (1923 - 2013) & American Painter & 1 & $12 / 11 / 1987$ & Box 3 \\
\hline Asbury, Edith Evans (1910 - 2008) & American Journalist & 2 & $06 / 12 / 1956$ & Box 3 \\
\hline Ashton, Sir Frederick (1904 - 1988) & American Dancer and Choreographer & 6 & $08 / 05 / 1978$ & $\begin{array}{l}\text { Box } 3 \\
\text { Oversized }\end{array}$ \\
\hline Asimov, Isaac (1919 - 1992) & American Author & 5 & $21 / 12 / 1990$ & $\begin{array}{l}\text { Box } 3 \\
\text { Oversized }\end{array}$ \\
\hline Atkinson, Brooks (1894 - 1984) & American Theatre Critic & 3 & $10 / 05 / 1951$ & $\begin{array}{l}\text { Box } 3 \\
\text { Box } 88\end{array}$ \\
\hline Attenborough, Sir. Richard (1923) & English Actor, Film Producer & 1 & $06 / 11 / 1986$ & Box 3 \\
\hline Auchincloss, Louis (1917 - 2010) & $\begin{array}{l}\text { American Lawyer, Historian and } \\
\text { Author }\end{array}$ & 1 & $11 / 05 / 1987$ & Box 3 \\
\hline Auster, Paul (1947) & American Author & 3 & $07 / 06 / 1993$ & Box 3 \\
\hline Avery, Milton (1885 - 1965) & American Painter & $\begin{array}{l}1 \\
4\end{array}$ & $\begin{array}{l}04 / 04 / 1944 \\
06 / 01 / 1961\end{array}$ & Box 3 \\
\hline Bacon, Peggy (1895 - 1987) & $\begin{array}{l}\text { American Painter, Printmaker and } \\
\text { Author }\end{array}$ & 3 & $17 / 09 / 1943$ & Box 4 \\
\hline Bailey, David (1938) & English Photographer & 8 & $20 / 02 / 1976$ & Box 60 \\
\hline Bakalar, David (Unknown) & American Sculptor & 3 & 29/09/1989 & Box 4 \\
\hline Baker, Dame Janet (1933) & British Opera Singer & 1 & $30 / 10 / 1978$ & Box 4 \\
\hline Baldaccini, Cesar (1921 - 1998) & French Sculptor & 2 & $01 / 05 / 1960$ & Box 10 \\
\hline Baldwin, Hanson W. (1903 - 1991) & American Journalist and Editor & 2 & $22 / 02 / 1951$ & Box 4 \\
\hline Barber, Charles F. (1917 - 2012) & American Businessman & 1 & $17 / 12 / 1973$ & Box 4 \\
\hline Barnet, Will (1911) & American Painter and Printmaker & 3 & $18 / 05 / 1993$ & Box 4 \\
\hline Barrymore, John Jr. (1932 - 2994) & American Actor & 1 & $05 / 07 / 1951$ & Box 4 \\
\hline Basaldella, Afro (1912 - 1976) & Italian Painter & 3 & $08 / 11 / 1959$ & Box 1 \\
\hline Bavan, Yolande (1942) & American Actress, Singer & 1 & $31 / 07 / 1973$ & Box 4 \\
\hline Baziotes, William (1912 - 1963) & American Painter & 4 & $30 / 03 / 1959$ & Box 4 \\
\hline Beall, Lester (1903 - 1969) & American Graphic Designer & 2 & $19 / 12 / 1951$ & Box 4 \\
\hline Beaton, Sir Cecil (1904 - 1980) & English Photographer & 3 & $27 / 05 / 1978$ & $\begin{array}{l}\text { Box } 4 \\
\text { Oversized }\end{array}$ \\
\hline Begelman, David (1921 - 1995) & American Film Producer & 1 & $12 / 08 / 1975$ & Box 4 \\
\hline Begin, Menachem (1913 - 1992) & Israeli Politician & 1 & $09 / 05 / 1979$ & Box 4 \\
\hline Bell, Larry (1939) & American Artist and Sculptor & 1 & $09 / 10 / 1967$ & Box 4 \\
\hline Bellows, Saul (1915 -2005) & Canadian-American Author & 3 & $27 / 05 / 2002$ & $\begin{array}{l}\text { Box } 55 \\
\text { Box } 73\end{array}$ \\
\hline Bemelmans, Ludwig (1898 - 1962) & Austrian Author & 3 & $03 / 12 / 1955$ & Box 4 \\
\hline Berger, Ben Mano (1897 - 1988) & American Businessman & 1 & $02 / 08 / 1964$ & Box 5 \\
\hline Berger, Meyer (1898 - 1959) & American Columnist and Journalist & 2 & $02 / 05 / 1951$ & $\begin{array}{l}\text { Box } 5 \\
\text { Box } 85\end{array}$ \\
\hline Berlin, Sir Isiah (1909 - 1997) & British Academic & 3 & $24 / 04 / 1979$ & Box 5 \\
\hline Berman, Eugene (1899 - 1972) & American Painter and Scenographer & 3 & $15 / 06 / 1966$ & Box 5 \\
\hline Bermingham, Philip (Unknown) & American Photographer & 1 & $06 / 05 / 2000$ & Box 5 \\
\hline Bernhard, Ruth (1905 - 2006) & American Photographer & $\begin{array}{l}2 \\
2\end{array}$ & $\begin{array}{l}22 / 09 / 1986 \\
21 / 07 / 1991\end{array}$ & Box 5 \\
\hline
\end{tabular}




\begin{tabular}{|c|c|c|c|c|}
\hline Bernstein, Leonard (1918 - 1990) & $\begin{array}{l}\text { American Composer, Conductor and } \\
\text { Author }\end{array}$ & $\begin{array}{l}1 \\
5 \\
3\end{array}$ & $\begin{array}{l}28 / 04 / 1959 \\
29 / 09 / 1946 \\
15 / 05 / 1968\end{array}$ & Box 5 \\
\hline $\begin{array}{l}\text { Bernstein, Theodore Menline (1904 - } \\
\text { 1979) }\end{array}$ & American Businessman & $\begin{array}{l}1 \\
2\end{array}$ & $\begin{array}{l}29 / 10 / 1951 \\
16 / 11 / 1954\end{array}$ & Box 5 \\
\hline Bertini, Gary (1927 - 2005) & Israeli Conductor and Composer & 3 & $30 / 03 / 1976$ & Box 5 \\
\hline Betjeman, Sir John (1906 - 1984) & English Poet, Writer and Broadcaster & 1 & $17 / 06 / 1978$ & Oversized \\
\hline Biemiller, Carl (1912 - 1979) & American Author & 1 & $11 / 01 / 1956$ & Box 5 \\
\hline Bienvenida, Antonio (1922 - 1975) & Spanish Bullfighter & 1 & $02 / 12 / 1964$ & Box 5 \\
\hline Biferie, Dan (Unknown) & American Photographer & 1 & $23 / 04 / 1989$ & Box 5 \\
\hline Birchfield, Charles (1893 - 1967) & $\begin{array}{l}\text { American Painter, Draftsman and } \\
\text { Illustrator }\end{array}$ & 2 & 03/09/1941 & Box 5 \\
\hline Bishop, Isabel (1902 - 1988) & American Painter & 1 & $24 / 03 / 1980$ & Box 5 \\
\hline Black, Charles R. Jr. (1947) & American Businessman & 1 & $05 / 01 / 1960$ & Box 5 \\
\hline Blass, Bill (1922 - 2002) & American Fashion Designer & 2 & 01/03/1979 & Box 5 \\
\hline Blitzstein, Marc (1905 - 1964) & American Composer & 8 & $10 / 06 / 1945$ & $\begin{array}{l}\text { Box } 5 \\
\text { Box } 84 \\
\text { Box } 86\end{array}$ \\
\hline Bloch, Julius Thiengen (1888 - 1966) & $\begin{array}{l}\text { American Painter, Draftsman and } \\
\text { Etcher }\end{array}$ & 1 & $06 / 06 / 1945$ & Box 6 \\
\hline Bocuse, Paul (1926) & French Chef & 5 & $02 / 03 / 1973$ & Box 6 \\
\hline Boesky, Ivan (1937) & American Stock Trader & 1 & $09 / 09 / 1982$ & Box 8 \\
\hline Bope Mabinshe (Unknown) & African Tribal Leader & 3 & $02 / 11 / 1958$ & Box 6 \\
\hline Boris, Margo (1903 - 1995) & American Painter & 3 & $01 / 09 / 1952$ & Box 6 \\
\hline Boulez, Pierre (1925) & French Composer & 3 & $05 / 04 / 1969$ & $\begin{array}{l}\text { Box } 6 \\
\text { Box } 73 \\
\end{array}$ \\
\hline Boycott, Geoffrey (1940) & English Cricketer & 1 & $24 / 10 / 1978$ & Oversized \\
\hline Bradley, Omar (1893 - 1981) & American Military Officer & 2 & $01 / 01 / 1951$ & Box 6 \\
\hline Brancusi, Constantin (1876 - 1957) & Romanian Sculptor & $\begin{array}{l}9 \\
1\end{array}$ & $\begin{array}{l}01 / 09 / 1956 \\
17 / 09 / 1969\end{array}$ & Box 6 \\
\hline Brandt, Bill (1904 - 1983) & English Photographer & $\begin{array}{l}7 \\
6\end{array}$ & $\begin{array}{l}12 / 07 / 1972 \\
26 / 05 / 1978\end{array}$ & Box 6 \\
\hline Braque, Georges (1882 - 1963) & $\begin{array}{l}\text { French Painter, Sculptor and } \\
\text { Draftsman }\end{array}$ & 8 & $08 / 10 / 1956$ & $\begin{array}{l}\text { Box } 6 \\
\text { Box } 73\end{array}$ \\
\hline Brassai (1899 - 1984) & French Photographer & 6 & $08 / 10 / 1976$ & $\begin{array}{l}\text { Box } 7 \\
\text { Box } 73 \\
\end{array}$ \\
\hline Bravo, Manuel Álvarez (1902 - 2002) & Mexican Photographer & 3 & $10 / 09 / 1987$ & Box 7 \\
\hline Breslin, Jimmy (1930) & American Journalist & 2 & $19 / 05 / 1971$ & Box 7 \\
\hline Brewster, Kingman (1919 - 1988) & American Educator and Diplomat & 2 & $30 / 10 / 1976$ & Box 7 \\
\hline Brickner, Balfour (1926 - 2005) & American Rabbi & 1 & $28 / 02 / 1997$ & Box 7 \\
\hline Britton, Burt (1938 - 2013) & English Art Collector & $\begin{array}{l}2 \\
2\end{array}$ & $\begin{array}{l}01 / 03 / 1977 \\
13 / 03 / 1979\end{array}$ & Box 7 \\
\hline Broderick, Matthew (1962) & American Actor & 4 & $11 / 04 / 1996$ & $\begin{array}{l}\text { Box } 7 \\
\text { Box } 73\end{array}$ \\
\hline Brodivitch, Alexy (1898 - 1971) & Russian Photographer & 1 & $06 / 10 / 1946$ & Box 7 \\
\hline Brook, Alexander (1898 - 1980) & American Painter & 3 & $12 / 09 / 1942$ & Box 7 \\
\hline Brothers, Joyce (1927 - 2013) & American Psychologist & 1 & $06 / 12 / 1975$ & Box 7 \\
\hline Brothers, Milton (Unknown) & Spouse to Joyce Brothers & 1 & $06 / 12 / 1975$ & Box 7 \\
\hline Brynner, Yul (1920 - 1985) & Russian-American Actor & 3 & $03 / 04 / 1968$ & Box 7 \\
\hline
\end{tabular}




\begin{tabular}{|c|c|c|c|c|}
\hline Buckley, Richard (1906 - 1960) & American Stage Performer & 1 & $25 / 01 / 1955$ & Box 7 \\
\hline Buffet, Bernard (1928 - 1999) & French Painter & 4 & $18 / 09 / 1956$ & Box 7 \\
\hline Buhl, Henry (Unknown) & American Photographer & 2 & $01 / 06 / 2000$ & Box 7 \\
\hline Bultman, Fritz (1919 - 1984) & $\begin{array}{l}\text { American Painter, Sculptor and } \\
\text { Draftsman }\end{array}$ & 2 & $26 / 08 / 1960$ & Box 6 \\
\hline Bunche, Ralph (1903 - 1971) & American Political Scientist & $\begin{array}{l}2 \\
1\end{array}$ & $\begin{array}{l}03 / 10 / 1951 \\
07 / 04 / 1962\end{array}$ & Box 7 \\
\hline Bunshaft, Gordon (1909 - 1990) & American Architect & $\begin{array}{l}1 \\
6\end{array}$ & $\begin{array}{l}06 / 10 / 1964 \\
12 / 07 / 1976\end{array}$ & Box 7 \\
\hline Bunshaft, Nina (Unknown) & Relation of Gordon Bunshaft & 6 & $12 / 07 / 1976$ & Box 7 \\
\hline Burden, Shirley (1909 - 1989) & American Writer and Photographer & 2 & $16 / 04 / 1976$ & Box 8 \\
\hline Burlyuk, David (1882 - 1967) & Ukrainian Painter and Writer & 4 & $04 / 09 / 1943$ & Box 8 \\
\hline Burnett, Leo (1891 - 1971) & American Advertiser & 1 & $08 / 08 / 1960$ & Box 8 \\
\hline Burns, Beverly (1949) & American Pilot & 4 & $08 / 05 / 1977$ & Box 8 \\
\hline Burns, Ric (1955) & American Filmmaker & 2 & $15 / 10 / 2003$ & Box 8 \\
\hline Burri, Alberto (1915 - 1995) & Italian Painter and Sculptor & $\begin{array}{l}3 \\
3\end{array}$ & $\begin{array}{l}01 / 06 / 1955 \\
16 / 06 / 1955\end{array}$ & $\begin{array}{l}\text { Box } 8 \\
\text { Box } 73\end{array}$ \\
\hline Burrows, Abe (1910 - 1985) & American Author and Director & 2 & $09 / 12 / 1960$ & Box 8 \\
\hline Burrows, James (1940) & American Director & 1 & Unknown & Box 8 \\
\hline Burson, Harold (1921) & American Businessman & 1 & $18 / 08 / 1982$ & Box 8 \\
\hline Burton, Harold H. (1888 - 1964) & American Politician and Lawyer & 5 & $20 / 06 / 1957$ & Box 8 \\
\hline Bush, George Herbert Walker (1924) & American President & 3 & $25 / 08 / 1998$ & Box 8 \\
\hline Bush, Vannevar (1890 - 1974) & American Engineer & 5 & $01 / 11 / 1949$ & Box 8 \\
\hline Butler, John Marshall (1897 - 1978) & American Politician & 1 & $20 / 12 / 1951$ & Box 8 \\
\hline Byrd, Senator Harry (1887 - 1966) & American Politician & 6 & $01 / 12 / 1951$ & Box 8 \\
\hline Cage, John (1912 - 1992) & American Composer and Printmaker & 3 & $30 / 03 / 1978$ & Box 9 \\
\hline Cahn, Sammy (1913 - 1993) & American Lyricist and Songwriter & 2 & $13 / 01 / 1963$ & Box 9 \\
\hline Calder, Alexander (1898 - 1976) & $\begin{array}{l}\text { American Sculptor, Painter and } \\
\text { Designer }\end{array}$ & 7 & $03 / 01 / 1951$ & Box 9 \\
\hline Callaghan, Leonard James (1912 - 2005) & British Prime Minister & 3 & 09/06/1978 & Box 9 \\
\hline Callahan, Harry (1912 - 1999) & American Photographer and Teacher & $\begin{array}{l}3 \\
3 \\
3\end{array}$ & $\begin{array}{l}10 / 02 / 1980 \\
05 / 04 / 1980 \\
21 / 09 / 1995\end{array}$ & Box 9 \\
\hline Caponigro, Paul (1932) & American Photographer & 3 & $10 / 08 / 1995$ & Box 9 \\
\hline Caro, Anthony (1924) & English Sculptor & 6 & $22 / 06 / 1966$ & Box 9 \\
\hline Caro, Robert (1935) & American Journalist & 2 & $08 / 08 / 1975$ & Box 9 \\
\hline Carter, Jimmy (1924) & American President & 2 & $29 / 10 / 1976$ & Box 10 \\
\hline Cartier-Bresson, Henri (1908 - 2004) & French Photographer & 3 & $07 / 01 / 1947$ & Box 10 \\
\hline Cary, Frank T. (1920 - 2006) & American Businessman & 2 & $02 / 12 / 1982$ & Box 10 \\
\hline Castelli, Leo (1907 - 1999) & American Art Dealer & 2 & $20 / 04 / 1973$ & Box 10 \\
\hline Catledge, Turner (1901 - 1983) & American Journalist & 2 & $06 / 07 / 1959$ & Box 10 \\
\hline Cerf, Bennet (1898 - 1971) & American Publisher & 2 & 01/11/1949 & Box 10 \\
\hline Chagall, Marc (1887 - 1985) & Belorussian Painter and Designer & $\begin{array}{l}16 \\
2\end{array}$ & $\begin{array}{l}11 / 01 / 1942 \\
03 / 07 / 1962\end{array}$ & Box 10 \\
\hline Chain, Ernest (1906 - 1979) & German Scientist & 1 & $24 / 06 / 1966$ & Box 10 \\
\hline Chamberlain, Richard (1934) & American Actor & 1 & 03/04/1968 & Box 10 \\
\hline Cheshire, Leonard (1917 - 1992) & British Pilot & 1 & $17 / 05 / 1978$ & Box 10 \\
\hline
\end{tabular}




\begin{tabular}{|c|c|c|c|c|}
\hline Child, Julia (1912 - 2004) & $\begin{array}{l}\text { American Chef, Author and } \\
\text { Television Personality }\end{array}$ & 1 & $29 / 06 / 1970$ & Box 11 \\
\hline Chrysler, Walter P. Jr. (1909 - 1988) & American Art Collector & 2 & $02 / 10 / 1962$ & Box 11 \\
\hline Clark, Kenneth McKenzie (1903 - 1983) & $\begin{array}{l}\text { British Author, Museum Director and } \\
\text { Art Historian }\end{array}$ & 3 & $01 / 05 / 1978$ & $\begin{array}{l}\text { Box } 11 \\
\text { Oversized }\end{array}$ \\
\hline Clarke, Thomas (1918 - 1993) & British Writer & 2 & $02 / 01 / 1949$ & Box 11 \\
\hline Clinton, William Jefferson "Bill" (1946) & American President & 6 & $17 / 08 / 1999$ & $\begin{array}{l}\text { Box } 11 \\
\text { Box } 73\end{array}$ \\
\hline Cocteau, Jean (1889 - 1963) & $\begin{array}{l}\text { French Writer, Filmmaker and } \\
\text { Draftsman }\end{array}$ & 6 & $01 / 05 / 1960$ & $\begin{array}{l}\text { Box } 11 \\
\text { Box } 73\end{array}$ \\
\hline Cohn, Arthur (1927) & Swiss Film Producer & 2 & 19/04/1962 & Box 11 \\
\hline Coiner, Charles (1943) & American Politician & 2 & $01 / 02 / 1950$ & Box 11 \\
\hline Comden, Betty (1915 - 2006) & American Comedian & 1 & $02 / 03 / 1997$ & Box 11 \\
\hline Conners, John "Jack" (1913 - 2001) & American Marimbist & 1 & $28 / 08 / 1975$ & Box 12 \\
\hline Conte, Richard (1920 - 1975) & American Actor & 8 & $01 / 11 / 1949$ & $\begin{array}{l}\text { Box } 12 \\
\text { Box } 83\end{array}$ \\
\hline Cook, Mariana (1955) & American Photographer & 2 & $12 / 11 / 1981$ & Box 12 \\
\hline Cooke, Alistair (1908 - 2004) & British/American Journalist & 2 & 25/04/1977 & $\begin{array}{l}\text { Box } 12 \\
\text { Box } 73\end{array}$ \\
\hline Cooke, Jerry (1921 - 2005) & Ukrainian American Photographer & 1 & $01 / 02 / 1951$ & Box 12 \\
\hline Copland, Aaron (1900 - 1990) & American Composer and Writer & 3 & Unknown & Box 33 \\
\hline Copley, William (1919 - 1996) & $\begin{array}{l}\text { American Painter, Gallerist, Collector } \\
\text { and Publisher }\end{array}$ & $\begin{array}{l}1 \\
2\end{array}$ & $\begin{array}{l}01 / 08 / 1974 \\
01 / 08 / 1976\end{array}$ & Box 12 \\
\hline Cosell, Howard (1918 - 1995) & American Journalist & 1 & $16 / 07 / 1983$ & Box 12 \\
\hline Coward, Noel (1899 - 1973) & $\begin{array}{l}\text { English Playwright, Composer, } \\
\text { Director, Actor and Singer }\end{array}$ & 4 & $17 / 10 / 1968$ & Box 12 \\
\hline Crain, Jeanne (1925 - 2003) & American Actress & 1 & $07 / 08 / 1949$ & Box 23 \\
\hline Cranston, Alan (1914 - 2000) & American Journalist and Politician & $\begin{array}{l}2 \\
3\end{array}$ & $\begin{array}{l}19 / 03 / 1980 \\
09 / 02 / 1983\end{array}$ & Box 13 \\
\hline $\begin{array}{l}\text { Crick, Francis Harry Compton (1916 - } \\
\text { 2004) }\end{array}$ & English Scientist & 5 & $06 / 01 / 1979$ & $\begin{array}{l}\text { Box } 13 \\
\text { Box } 73\end{array}$ \\
\hline Criss, Francis (1901 -1973) & British Painter & 2 & $06 / 04 / 1944$ & Box 13 \\
\hline Crowther, Bosley (1905 - 1981) & American Journalist & 2 & $01 / 01 / 1952$ & Box 13 \\
\hline Culligan, Matthew J. (1919 - 2002) & American Publisher & 1 & $27 / 07 / 1962$ & Box 13 \\
\hline Cummings, Nathan (1896-1985) & Canadian-American Businessman & 4 & $13 / 11 / 1981$ & Box 13 \\
\hline Cunningham, Imogen (1883 - 1976) & American Photographer & $\begin{array}{l}3 \\
1\end{array}$ & $\begin{array}{l}20 / 05 / 1969 \\
28 / 02 / 1975\end{array}$ & Box 13 \\
\hline Dahl-Wolfe, Louise (1895 - 1989) & American Photographer & 2 & $25 / 09 / 1984$ & Box 13 \\
\hline Daley, Arthur & & 3 & $01 / 06 / 1951$ & Box 13 \\
\hline Dali, Salvador (1904 - 1989) & Spanish Painter and Printmaker & 1 & $10 / 01 / 1951$ & Box 13 \\
\hline Daniel, E. Clifton (1912 - 2000) & American Editor & $\begin{array}{l}1 \\
1\end{array}$ & $\begin{array}{l}04 / 03 / 1945 \\
23 / 04 / 1956\end{array}$ & $\begin{array}{l}\text { Box } 13 \\
\text { Box } 61\end{array}$ \\
\hline Danzig, Allison (1898 - 1987) & American Sportswriter & 1 & 06/06/1956 & Box 13 \\
\hline Daphnis, Nassos (1914 - 2010) & Greek-American Painter & 1 & $05 / 09 / 1965$ & Box 13 \\
\hline Dassin, Jules (1911 - 2008) & American Director & 2 & $18 / 04 / 1961$ & Box 13 \\
\hline Dater, Judy (1941) & American Photographer & $\begin{array}{l}2 \\
3 \\
1\end{array}$ & $\begin{array}{l}31 / 03 / 1974 \\
12 / 06 / 1980 \\
19 / 08 / 1977\end{array}$ & $\begin{array}{l}\text { Box } 13 \\
\text { Box } 73\end{array}$ \\
\hline Davidson, Jo (1883 - 1952) & American Sculptor & 1 & $03 / 06 / 1945$ & Box 13 \\
\hline
\end{tabular}




\begin{tabular}{|c|c|c|c|c|}
\hline Davies, David (1946) & British Writer & 1 & $23 / 11 / 1975$ & Box 13 \\
\hline Davis, Clive (1932) & American Record Producer & 1 & $19 / 08 / 1975$ & Box 14 \\
\hline Davis, Stuart (1892 - 1964) & American Painter and Printmaker & $\begin{array}{l}1 \\
4\end{array}$ & $\begin{array}{l}08 / 12 / 1941 \\
29 / 10 / 1957\end{array}$ & Box 14 \\
\hline Dayan, Moshe (1915 - 1981) & Israeli Military Leader & $\begin{array}{l}1 \\
1 \\
1\end{array}$ & $\begin{array}{l}01 / 08 / 1959 \\
24 / 11 / 1967 \\
18 / 04 / 1979\end{array}$ & Box 14 \\
\hline de Chirico, Giorgio (1888 - 1978) & $\begin{array}{l}\text { Italian Painter, Writer and } \\
\text { Scenographer }\end{array}$ & 6 & $01 / 12 / 1957$ & Box 11 \\
\hline de Hoffman, Frederic (1924) & American Physicist & 3 & $09 / 11 / 1962$ & Box 14 \\
\hline de Kooning, Willem (1903 - 1997) & American Painter and Sculptor & $\begin{array}{l}3 \\
1 \\
6 \\
1\end{array}$ & $\begin{array}{l}05 / 02 / 1959 \\
25 / 05 / 1959 \\
15 / 06 / 1959 \\
22 / 10 / 1982\end{array}$ & Box 14 \\
\hline de Mille, Agnes George (1905 - 1993) & American Dancer and Choreographer & 2 & $30 / 11 / 1955$ & Box 14 \\
\hline de Rothschild, Evelyn (1931) & British Financier & 2 & $09 / 02 / 1981$ & Box 50 \\
\hline de Sica, Vittorio (1901 - 1974) & Italian Director and Actor & 2 & $13 / 06 / 1966$ & Box 14 \\
\hline de Waart, Edo (1941) & Dutch Conductor & 2 & $05 / 04 / 1995$ & Box 15 \\
\hline Delany, Shelagh (1938 - 2011) & English Screenwriter & 5 & $07 / 08 / 1961$ & Box 14 \\
\hline Delillo, Don (1936) & American Essayist & 2 & $13 / 05 / 1997$ & Box 14 \\
\hline DeLorean, John (1925 - 2005) & American Engineer & 3 & $05 / 01 / 1981$ & Box 14 \\
\hline Dench, Dame Judith Olivia "Judi" (1934) & English Actress & 1 & $12 / 05 / 1978$ & Oversized \\
\hline Deniel, Enrique Pla Y (UNKNOWN) & Spanish Catholic Arch Bishop & 2 & $09 / 12 / 1964$ & Box 9 \\
\hline $\begin{array}{l}\text { Denning, Alfred Thompson "Tom" (1899 } \\
\text { - 1999) }\end{array}$ & British Lawyer and Judge & 2 & $24 / 05 / 1978$ & $\begin{array}{l}\text { Box } 14 \\
\text { Oversized }\end{array}$ \\
\hline DeSapio, Carmine (1908 - 2004) & American Politician & 2 & $01 / 11 / 1954$ & Box 14 \\
\hline Dewey, Thomas E. (1902 - 1971) & American Governor & 1 & $04 / 09 / 1954$ & Box 15 \\
\hline Dickey, James (1923 - 1997) & American Poet and Author & 3 & $09 / 09 / 1981$ & Box 15 \\
\hline Dickinson, Edwin (1891 - 1978) & American Painter & 3 & $29 / 06 / 1960$ & Box 15 \\
\hline Diebenkorn, Richard (1922) & American Painter & 1 & $14 / 11 / 1985$ & Box 15 \\
\hline Dietrich, Marlene (1901 - 1992) & German-American Actress & 3 & $02 / 06 / 1948$ & Box 15 \\
\hline Dine, Jim (1935) & $\begin{array}{l}\text { American Painter, Sculptor and } \\
\text { Printmaker }\end{array}$ & $\begin{array}{l}9 \\
2\end{array}$ & $\begin{array}{l}10 / 02 / 1977 \\
17 / 01 / 1978\end{array}$ & Box 15 \\
\hline Doisneau, Robert (1912 - 1994) & French Photographer & 2 & $26 / 04 / 1981$ & Box 15 \\
\hline Dolger, Henry (1909 - 1997) & American Medical Doctor & 2 & 13/06/1958 & Box 15 \\
\hline Donovan, Terence (1936 - 1996) & English Photographer & 7 & $20 / 02 / 1976$ & Box 60 \\
\hline $\begin{array}{l}\text { Douglas, Justice William O. (1939 - } \\
\text { 1975) }\end{array}$ & American Justice & 2 & $12 / 12 / 1961$ & Box 15 \\
\hline Douglas, Kirk (1916) & American Actor & 1 & $05 / 04 / 1949$ & Box 15 \\
\hline Douglas, Lewis Williams (1894 - 1974) & American Politician & 2 & $10 / 09 / 1947$ & Box 15 \\
\hline Douglas, Paul H. (1892 - 1976) & American Politician and Economist & 5 & $14 / 07 / 1953$ & $\begin{array}{l}\text { Box } 15 \\
\text { Box } 82\end{array}$ \\
\hline $\begin{array}{l}\text { Douglas-Home, Alexander "Alec" } \\
\text { Frederick (1903 - 1995) }\end{array}$ & British Politician & 1 & $24 / 05 / 1978$ & Oversized \\
\hline Downes, Olin (1886 - 1955) & American Music Critic & 1 & $18 / 01 / 1954$ & Box 15 \\
\hline
\end{tabular}




\begin{tabular}{|c|c|c|c|c|}
\hline Dryfoos, Orville E. (1912 - 1963) & American Publisher & $\begin{array}{l}1 \\
1\end{array}$ & $\begin{array}{l}18 / 10 / 1956 \\
13 / 03 / 1957\end{array}$ & Box 15 \\
\hline Dubuffet, Jean (1901 - 1985) & French Painter and Sculptor & 6 & $10 / 09 / 1956$ & Box 16 \\
\hline Duchamp, Marcel (1887 - 1968) & French Painter, Sculptor and Writer & $\begin{array}{l}5 \\
1 \\
12\end{array}$ & $\begin{array}{l}14 / 09 / 1942 \\
28 / 01 / 1966 \\
09 / 01 / 1967\end{array}$ & Box 16 \\
\hline Duffy, Brian (1933 - 2010) & English Photographer & 8 & $20 / 02 / 1976$ & Box 60 \\
\hline Dufy, Raoul (1877 - 1953) & $\begin{array}{l}\text { French Painter, Designer and } \\
\text { Ceramicist }\end{array}$ & 4 & $01 / 02 / 1951$ & Box 16 \\
\hline Dugan, George & & 1 & $23 / 09 / 1954$ & Box 16 \\
\hline Duhamel, Georges (1884 - 1966) & French Author & 1 & $06 / 10 / 1956$ & Box 1 \\
\hline Dumaine, Alexandre (1895 - 1974) & French Chef & 2 & $24 / 09 / 1956$ & Box 16 \\
\hline Dunkelman, Elaine (Unknown) & Relation to Arnold Dunkelman & 2 & $13 / 03 / 1983$ & $\begin{array}{l}\text { Box } 16 \\
\text { Box } 57\end{array}$ \\
\hline Eames, Charles (1907 - 1978) & American Designer & 5 & $16 / 11 / 1974$ & Box 16 \\
\hline Eames, Ray (1916 - 1988) & $\begin{array}{l}\text { American Designer, Architect and } \\
\text { Filmmaker }\end{array}$ & 5 & $16 / 11 / 1974$ & Box 16 \\
\hline Eban, Abba (1915 - 2002) & Israeli Politician & 1 & $13 / 10 / 1968$ & Box 16 \\
\hline Eccles, Sir David (1904 - 1999) & British Politician & 1 & $01 / 03 / 1954$ & Box 16 \\
\hline Edgerton, Harold (1903 - 1990) & American Scientist & 4 & $10 / 10 / 1962$ & Box 35 \\
\hline Effront, Nadine (Unknown) & French? Artist & 2 & $10 / 05 / 1963$ & Box 16 \\
\hline Ehlers, Hermann (1904 - 1954) & German Politician & 1 & $01 / 03 / 1954$ & Box 16 \\
\hline Eisenhower, Dwight D. (1890 - 1969) & American President & $\begin{array}{l}10 \\
1\end{array}$ & $\begin{array}{l}01 / 03 / 1950 \\
12 / 06 / 1952\end{array}$ & Box 17 \\
\hline Elliot, Mark (1939) & American Voice Over Artist & 1 & $22 / 07 / 1978$ & Box 17 \\
\hline Ellison, Ralph (1914 - 1994) & American Novelist & 3 & $26 / 01 / 1953$ & Box 36 \\
\hline Embry, Lloyd (1913 - 1979) & American Artist & 1 & $01 / 02 / 1956$ & Box 17 \\
\hline Emmerich, André (2914 - 2007) & German-American Gallerist & $\begin{array}{l}1 \\
1\end{array}$ & $\begin{array}{l}26 / 09 / 1973 \\
31 / 01 / 1975 \\
\end{array}$ & Box 17 \\
\hline Englander, Caryl (Unknown) & Spouse to Israel Englander & 3 & $27 / 05 / 2004$ & Box 17 \\
\hline Englander, Israel "Izzy" (1948) & American Hedge Fund Manager & 3 & $27 / 05 / 2004$ & Box 17 \\
\hline Enyeart, James (1943) & American Photographer & 2 & $01 / 05 / 1992$ & Box 17 \\
\hline Epstein, Jason (1928) & American Editor & 1 & $07 / 02 / 1972$ & Box 17 \\
\hline Ernst, Jimmy (1920 - 1984) & American Painter & 4 & $29 / 08 / 1970$ & Box 17 \\
\hline Ernst, Max (1891 -1976) & German Painter, Sculptor and Author & 7 & $18 / 01 / 1942$ & $\begin{array}{l}\text { Box } 17 \\
\text { Box } 86\end{array}$ \\
\hline Esaki, Leo (1925) & Japanese Physicist & 2 & 20/09/1976 & Box 27 \\
\hline Escobar, Maria Sol (1930) & French Sculptor & 2 & $20 / 07 / 1985$ & Box 17 \\
\hline Eshkol, Levi (1895 - 1969) & Israeli Prime Minister & 1 & $24 / 11 / 1967$ & Box 17 \\
\hline Estes, Richard (1932) & American Painter & 2 & $13 / 03 / 1980$ & Box 17 \\
\hline Evans, Dame Edith Mary (1888 - 1976) & English Actress & 1 & $29 / 05 / 1968$ & Box 17 \\
\hline Evans, Gil (1912 - 1988) & Canadian Pianist & 1 & $21 / 10 / 1960$ & Box 17 \\
\hline Evans, Harold (1928) & British Journalist & 1 & $20 / 06 / 1978$ & Box 17 \\
\hline Evans, Sir Geraint (1922 - 1992) & Welsh Singer & 1 & $25 / 10 / 1978$ & Box 17 \\
\hline Evergood, Philip (1901 - 1973) & $\begin{array}{l}\text { American Painter, Illustrator and } \\
\text { Sculptor }\end{array}$ & 4 & $4 / 11 / 1944$ & Box 17 \\
\hline Fabray, Nanette (1920) & $\begin{array}{l}\text { American Actress, Singer, Dancer } \\
\text { and Activist }\end{array}$ & 1 & $16 / 05 / 1956$ & Box 18 \\
\hline Fairchild, John (1943) & American Basketball Player & 3 & $14 / 09 / 1981$ & Box 18 \\
\hline
\end{tabular}




\begin{tabular}{|c|c|c|c|c|}
\hline Farrell, Suzane (1945) & American Ballerina & 1 & 24/12/1968 & Box 18 \\
\hline Feinberg, Wilfred (1920) & American Judge & $\begin{array}{l}1 \\
1\end{array}$ & $\begin{array}{l}21 / 06 / 1965 \\
22 / 02 / 1984\end{array}$ & Box 18 \\
\hline Feininger, Lyonel (1871 - 1956) & German-American Painter & 1 & $13 / 09 / 1945$ & Box 20 \\
\hline Feller, Bob (1918 - 2010) & $\begin{array}{l}\text { American Major League Baseball } \\
\text { Player }\end{array}$ & 2 & $10 / 05 / 1956$ & Box 18 \\
\hline Ferber, Herbert (1906 - 1991) & American Sculptor and Painter & 3 & 29/01/1976 & Box 18 \\
\hline Fiene, Ernest (1894 - 1965) & American Graphic Artist & 3 & 07/01/1942 & Box 18 \\
\hline Filmus, Tully (1903) & Bessarabian Painter & 1 & $07 / 04 / 1944$ & Box 18 \\
\hline Finck, Furman (1900 - 1997) & American Artist & 1 & $19 / 09 / 1948$ & Box 18 \\
\hline Fine, Benjamin (1905 - 1975) & American Author & 1 & $24 / 09 / 1953$ & Box 18 \\
\hline Fink, Denman (1880 - 1956) & American Painter & 2 & 13/01/1940 & Box 18 \\
\hline Firkusny, Rudolf (1912 - 1994) & Czech-American Pianist & 1 & $20 / 04 / 1948$ & Box 18 \\
\hline Fischel, Eric (1948) & American Painter & 2 & $28 / 02 / 1984$ & Box 18 \\
\hline Flavin, Dan (1933 - 1996) & $\begin{array}{l}\text { American Installation Artist and } \\
\text { Painter }\end{array}$ & 4 & $25 / 10 / 1967$ & $\begin{array}{l}\text { Box } 18 \\
\text { Oversized }\end{array}$ \\
\hline Florsheim, Richard (Dick) (1916 - 1979) & American Artist & 1 & $20 / 08 / 1958$ & Box 19 \\
\hline Flynn, William (1890 - 1944) & American Architect & 2 & $18 / 10 / 1993$ & Box 19 \\
\hline Foch, Nina (1924 - 2008) & Dutch-American Actress & 2 & $01 / 01 / 1952$ & Box 43 \\
\hline Ford, Gerald R. (1913 - 2006) & American President & 8 & $22 / 01 / 1975$ & $\begin{array}{l}\text { Box } 19 \\
\text { Oversized }\end{array}$ \\
\hline Ford, Henry II (1917 - 1987) & American Businessman & $\begin{array}{l}1 \\
1 \\
2\end{array}$ & $\begin{array}{l}11 / 09 / 1957 \\
08 / 10 / 1957 \\
27 / 06 / 1960\end{array}$ & Box 19 \\
\hline Forman, Carl (1914 - 1984) & American Screenwriter & 1 & $03 / 04 / 1961$ & Box 19 \\
\hline Foss, Lukas (1922 - 2009) & American Composer & 1 & $13 / 03 / 1962$ & Box 19 \\
\hline Francis, Sam (1923 - 1994) & American Painter & $\begin{array}{l}2 \\
3\end{array}$ & $\begin{array}{l}31 / 07 / 1957 \\
06 / 11 / 1985\end{array}$ & Box 19 \\
\hline Franco, Francisco (1892 - 1975) & Spansih Military Officer & 1 & $05 / 12 / 1964$ & Box 19 \\
\hline Frank, Otto $(1889$ - 1980) & German Businessman & 5 & $01 / 05 / 1960$ & Box 19 \\
\hline Frankenthaler, Helen (1928 - 2011) & American Painter & $\begin{array}{l}7 \\
1\end{array}$ & $\begin{array}{l}15 / 08 / 1963 \\
27 / 02 / 1989\end{array}$ & Box 19 \\
\hline Frankfurter, Felix (1882 - 1965) & American Justice & 1 & 19/06/1957 & Box 20 \\
\hline Franz, Jantzen (1964) & American Photographer & 1 & 20/05/1997 & Box 20 \\
\hline Freedman, Doris $(1928-1981)$ & American Artist & 1 & $18 / 05 / 1968$ & Box 20 \\
\hline Friedlander, Lee (1934) & American Photographer & 3 & $08 / 04 / 1976$ & Box 20 \\
\hline Friendly, Fred W. (1915 - 1998) & American Businessman and Producer & $\begin{array}{l}1 \\
1 \\
\end{array}$ & $\begin{array}{l}10 / 09 / 1968 \\
12 / 09 / 1983 \\
\end{array}$ & $\begin{array}{l}\text { Box } 20 \\
\text { Box } 25\end{array}$ \\
\hline Froman, Jane (1907 - 1980) & American Singer and Actress & 1 & $13 / 11 / 1952$ & Box 20 \\
\hline Frost, Robert (1874 - 1963) & American Poet & 7 & $23 / 03 / 1956$ & Box 20 \\
\hline Gabo, Naum (1890 - 1977) & $\begin{array}{l}\text { Russian-American Sculptor and } \\
\text { Designer }\end{array}$ & 7 & $27 / 07 / 1975$ & Box 20 \\
\hline Gabriel, Peter (1950) & English Musician & 5 & $01 / 07 / 2002$ & Box 20 \\
\hline Gagnebin, Albert P. (1909 - 1999) & American Businessman & 1 & $05 / 05 / 1964$ & Box 20 \\
\hline Galbraith, John Kenneth (1908 - 2006) & Canadian Economist & 2 & $15 / 07 / 1981$ & Box 20 \\
\hline Gamson, Arnold (1926) & American Conductor & 1 & $04 / 10 / 1958$ & Box 20 \\
\hline Gardner, Ava (1922 - 1990) & American Actress & 1 & $02 / 01 / 1949$ & Box 20 \\
\hline Gardner, Cowles Jr. (1902 - 1985) & American Editor & 3 & $23 / 01 / 1964$ & Box 20 \\
\hline
\end{tabular}




\begin{tabular}{|c|c|c|c|c|}
\hline Garfield, John (1913 - 1952) & American Actor & $\begin{array}{l}1 \\
4 \\
1\end{array}$ & $\begin{array}{l}10 / 06 / 1948 \\
11 / 06 / 1948 \\
12 / 06 / 1948\end{array}$ & Box 20 \\
\hline Garroway, Dave (1913 - 1982) & American Television Personality & 3 & $22 / 05 / 1957$ & Box 20 \\
\hline Gavin, John (1931) & American Actor & 1 & 03/04/1968 & Box 20 \\
\hline Geddes, Barbara Bell (1922 - 2005) & American Actress and Author & 1 & $21 / 06 / 1955$ & Box 20 \\
\hline Gelb, Jan (1906 - 1978) & American Artist & 2 & $23 / 08 / 1960$ & Box 36 \\
\hline Geldzahler, Henry (1935 - 1994) & $\begin{array}{l}\text { Belgian Art Curator, Historian and } \\
\text { Critic }\end{array}$ & 5 & $25 / 12 / 1972$ & Box 21 \\
\hline George, Walter F (1878 - 1957) & American Politician & $\begin{array}{l}1 \\
4\end{array}$ & $\begin{array}{l}01 / 12 / 1951 \\
25 / 06 / 1953\end{array}$ & Box 21 \\
\hline Gerber, David (1923 - 2010) & American Television Producer & 1 & $13 / 08 / 1975$ & Box 21 \\
\hline Gergiev, Valerie (1953) & Russian Conductor & 2 & $23 / 12 / 1997$ & $\begin{array}{l}\text { Box } 21 \\
\text { Box } 73\end{array}$ \\
\hline Gersheim, Helmut (1913 - 1995) & German Historian and Photographer & 1 & $04 / 11 / 1984$ & Box 21 \\
\hline Gerstenberg, Richard (1910 - 2002) & American Businessman & 1 & $18 / 11 / 1971$ & Box 21 \\
\hline Giacometti, Alberto (1901 - 1966) & $\begin{array}{l}\text { Swiss Painter, Sculptor and } \\
\text { Printmaker }\end{array}$ & 10 & $12 / 05 / 1954$ & Box 21 \\
\hline Gibson, Ralph (1939) & American Art Photographer & 1 & $26 / 07 / 2001$ & Box 21 \\
\hline Gielen, Michael (1927) & American Conductor & 1 & $01 / 11 / 1971$ & Box 21 \\
\hline Gielgud, Sir John (1904 - 2000) & English Actor, Director & 6 & $13 / 06 / 1978$ & $\begin{array}{l}\text { Box } 21 \\
\text { Oversized }\end{array}$ \\
\hline Gingold, Hermione (1897 - 1987) & English Actress & 2 & $20 / 09 / 1962$ & $\begin{array}{l}\text { Box } 21 \\
\text { Oversized }\end{array}$ \\
\hline Ginsberg, Allen (1926 - 1997) & American Poet & 4 & $01 / 11 / 1985$ & Box 21 \\
\hline Glass, Philip (1937) & American Composer & 9 & $14 / 06 / 1981$ & Box 22 \\
\hline Glimcher, Arnold "Arne" (1938) & American Art Dealer, Director & 4 & $21 / 07 / 1972$ & Box 22 \\
\hline Godel, Kurt (1906 - 1978) & Austrian-American Mathematician & 5 & $01 / 05 / 1956$ & Box 22 \\
\hline Gold, Herbert (1924) & American Novelist & 3 & $16 / 12 / 1969$ & Box 22 \\
\hline Goldenson, Leonard (1905 - 1999) & American Businessman & $\begin{array}{l}2 \\
2\end{array}$ & $\begin{array}{l}28 / 01 / 1957 \\
03 / 04 / 1979\end{array}$ & Box 22 \\
\hline Goldman, Jack E. (1921 - 2011) & American Physicist and Businessman & 1 & $12 / 02 / 1974$ & Box 22 \\
\hline Golub, William (1904 - 1992) & American Businessman & 1 & $01 / 03 / 1965$ & Box 22 \\
\hline Gomory, Ralph E. (1929) & American Scientist and Businessman & 2 & $17 / 01 / 1972$ & Box 22 \\
\hline Goodman, Arnold Abraham (1915 - 1995) & British Politician & 1 & $17 / 06 / 1078$ & Oversized \\
\hline Goodrich, Lloyd (1897 - 1987) & American Art Historian & 1 & $27 / 12 / 1962$ & Box 22 \\
\hline Gordimer, Nadine (1923) & South African Writer & 1 & 03/05/1982 & Box 22 \\
\hline Gottlieb, Adolph (1903 - 1974) & American Painter & $\begin{array}{l}2 \\
7 \\
4\end{array}$ & $\begin{array}{l}01 / 08 / 1953 \\
06 / 02 / 1970 \\
06 / 06 / 1973\end{array}$ & Box 22 \\
\hline Gould, Frederick (1879 - 1971) & English Trade Unionist & 2 & $11 / 10 / 1995$ & Box 22 \\
\hline Gould, Glenn (1932 - 1982) & Canadian Pianist & $\begin{array}{l}1 \\
4\end{array}$ & $\begin{array}{l}10 / 10 / 1959 \\
28 / 11 / 1963\end{array}$ & Box 22 \\
\hline Gould, Jack (1914 - 1993) & American Journalist & 2 & $10 / 07 / 1951$ & Box 22 \\
\hline Gould, Stephen Jay (1941 - 2002) & American Scientist & 2 & $07 / 06 / 1995$ & Box 22 \\
\hline
\end{tabular}




\begin{tabular}{|c|c|c|c|c|}
\hline Grade, Michael Ian (1943) & English Broadcast Executive & 1 & $10 / 05 / 1978$ & Oversized \\
\hline Graffman, Gary (1928) & American Pianist & 2 & $12 / 01 / 1961$ & Box 23 \\
\hline Graham, Katharine (1917 - 2001) & American Publisher & $\begin{array}{l}2 \\
1\end{array}$ & $\begin{array}{l}14 / 02 / 1973 \\
18 / 12 / 1996\end{array}$ & Box 25 \\
\hline Graham, Martha (1893 - 1991) & American Dancer and Choreographer & 12 & $02 / 03 / 1961$ & Box 23 \\
\hline Green, Adolph (1914 - 2002) & American Lyricist and Playwright & 1 & $02 / 03 / 1977$ & Box 11 \\
\hline Greenberg, Clement (1909 - 1994) & American Art Critic & 1 & $26 / 12 / 1972$ & Box 23 \\
\hline Gregorian, Vartan (1934) & Armenian-American Academic & 2 & 28/07/1983 & Box 23 \\
\hline Grooms, Red (1937) & American Painter and Sculptor & $\begin{array}{l}12 \\
2\end{array}$ & $\begin{array}{l}15 / 01 / 1974 \\
27 / 03 / 1980\end{array}$ & $\begin{array}{l}\text { Box } 23 \\
\text { Box } 73\end{array}$ \\
\hline Gropper, William (1897 - 1977) & $\begin{array}{l}\text { American Cartoonist, Painter, } \\
\text { Lithographer and Muralist }\end{array}$ & 1 & $23 / 09 / 1943$ & Box 23 \\
\hline Gross, Chaim (1904 - 1991) & $\begin{array}{l}\text { American Sculptor, Painter and } \\
\text { Printmaker }\end{array}$ & $\begin{array}{l}1 \\
2 \\
3 \\
1 \\
1 \\
3 \\
1 \\
1\end{array}$ & $\begin{array}{l}11 / 01 / 1942 \\
12 / 01 / 1942 \\
01 / 09 / 1942 \\
25 / 04 / 1959 \\
13 / 08 / 1960 \\
24 / 04 / 1971 \\
15 / 04 / 1985 \\
06 / 01 / 1991\end{array}$ & Box 23 \\
\hline Grosz, George (1893 - 1959) & German Painter and Printmaker & $\begin{array}{l}4 \\
1\end{array}$ & $\begin{array}{l}19 / 01 / 1942 \\
20 / 01 / 1942\end{array}$ & Box 23 \\
\hline Groth, John (1908 - 1988) & American Artist & $\begin{array}{l}1 \\
1\end{array}$ & $\begin{array}{l}09 / 01 / 1942 \\
18 / 09 / 1946\end{array}$ & \\
\hline Grube, Ernst (1932 - 2011) & German Historian & 1 & $12 / 04 / 1968$ & Box 24 \\
\hline Guare, John (1938) & American Playwright & 2 & $27 / 10 / 1995$ & Box 24 \\
\hline Guber, Howard Peter (1942) & American Film Producer & 2 & $11 / 08 / 1975$ & Box 19 \\
\hline Guggenheim, Peggy (1898 - 1979) & American Art Collector & 2 & $08 / 07 / 1954$ & Box 24 \\
\hline Gugliemi, Louis (1916 - 1991) & Italian Musician & 2 & $12 / 09 / 1945$ & Box 24 \\
\hline Guinness, Sir Alec (1914 - 2000) & English Actor & 6 & $03 / 05 / 1978$ & Box 24 \\
\hline Gurion, David Ben (1886 - 1973) & Israeli Prime Minister & $\begin{array}{l}5 \\
3 \\
3\end{array}$ & $\begin{array}{l}01 / 05 / 1951 \\
10 / 05 / 1965 \\
24 / 11 / 1967\end{array}$ & $\begin{array}{l}\text { Box } 5 \\
\text { Oversized } \\
\text { Box } 73\end{array}$ \\
\hline Guston, Philip (1913 - 1980) & American Painter & 4 & $15 / 04 / 1947$ & Box 24 \\
\hline Gutt, Camille (1884 - 1971) & Belgian Politician and Economist & 1 & $01 / 03 / 1948$ & \\
\hline $\begin{array}{l}\text { Hadley, Albert Livingston Jr. (1920 - } \\
\text { 2012) }\end{array}$ & American Interior Designer & 1 & $20 / 03 / 1973$ & Box 24 \\
\hline Hahn, Otto (1879 - 1968) & German Scientist & 1 & $10 / 07 / 1964$ & Box 24 \\
\hline Haimovitz, Matt (1970) & Israeli Cellist & 1 & $05 / 06 / 1990$ & Box 24 \\
\hline Halberstam, David (1934 - 2007) & American Journalist & 2 & $30 / 03 / 1993$ & Box 24 \\
\hline Hall, Sir Peter (1930) & English Theatre and Film Director & 3 & $01 / 06 / 1978$ & $\begin{array}{l}\text { Box } 24 \\
\text { Oversized }\end{array}$ \\
\hline Hamilton, Edward (1947) & American Sculptor & 2 & 06/08/1965 & Box 24 \\
\hline Hamilton, Sir Denis (1918 - 1988) & British Newspaper Editor & 2 & $06 / 12 / 1979$ & Box 24 \\
\hline Hamilton, Thomas (1975) & American Basketball Player & 1 & $17 / 10 / 1952$ & Box 24 \\
\hline Hampshire, Susan (1937) & English Actress & 1 & $12 / 05 / 1978$ & Oversized \\
\hline
\end{tabular}




\begin{tabular}{|c|c|c|c|c|}
\hline Hanauer, Chip (1954) & American Hydroplane Pilot & 1 & $16 / 01 / 1986$ & Box 24 \\
\hline Hare, David (1917 - 1992) & $\begin{array}{l}\text { American Sculptor, Photographer and } \\
\text { Painter }\end{array}$ & 6 & $01 / 09 / 1952$ & $\begin{array}{l}\text { Box } 24 \\
\text { Box } 85\end{array}$ \\
\hline Harel, Isser (1912 - 2003) & Israeli Intelligence Officer & 1 & $24 / 11 / 1967$ & Box 24 \\
\hline Harlan, John Marshall II (1899 - 1971) & American Jurist & 2 & 20/06/1957 & Box 24 \\
\hline Harmon, Lily (1912 - 1998) & American Painter & 3 & $04 / 09 / 1968$ & Box 24 \\
\hline Harriman, William Averell (1891 - 1986) & American Politician & 3 & $08 / 09 / 1954$ & Box 24 \\
\hline Harrison, George (1943 - 2001) & English Musician and Songwriter & $\begin{array}{l}1 \\
1\end{array}$ & $\begin{array}{l}24 / 09 / 1974 \\
12 / 06 / 1978\end{array}$ & Box 25 \\
\hline Hausner, Gideon (1915 - 1990) & Israeli Politician and Jurist & 2 & $16 / 09 / 1962$ & Box 25 \\
\hline Hawkins, Bill (1940) & Canadian Writer and Poet & 1 & $15 / 03 / 1957$ & Box 25 \\
\hline Hawthorne, Nigel (1929 - 2001) & English Actor & 2 & $08 / 10 / 1993$ & Box 25 \\
\hline Hayter, Stanley William (1901 - 1988) & $\begin{array}{l}\text { English Printmaker, Draftsman and } \\
\text { Painter }\end{array}$ & 4 & $04 / 20 / 1947$ & Box 25 \\
\hline Hayward, Leland (1902 - 1971) & American Theatrical Producer & 2 & $16 / 06 / 1955$ & Box 25 \\
\hline Heath, Rt. Hm. Edward (1916 - 2005) & British Politician & 1 & 05/06/1978 & Oversized \\
\hline Heineman, Ben W. (1914 - 2012) & American Attorney and Executive & 1 & $19 / 01 / 1978$ & Box 25 \\
\hline Heiskell, Andrew (1915 - 2003) & American Businessman & 3 & $18 / 01 / 1956$ & Box 25 \\
\hline Heisler, Greg (1954) & American Photographer & 2 & 26/07/1989 & Box 25 \\
\hline Heller, Walter (1915 - 1987) & American Economist & 2 & $08 / 07 / 1965$ & Box 25 \\
\hline Hellman, Lillian (1905 - 1984) & American Author and Playwright & 6 & $27 / 03 / 1973$ & Box 25 \\
\hline Henreid, Paul (1908 - 1992) & Trieste-born Actor and Director & 1 & $03 / 04 / 1968$ & Box 25 \\
\hline Hepburn, Katharine (1907 - 2003) & American Actor & 2 & $11 / 07 / 1954$ & Box 25 \\
\hline Herblock (1909 - 2001) & American Cartoonist & 2 & $15 / 11 / 1961$ & Box 6 \\
\hline Hesburgh, Theodore (1917) & American Priest & 1 & $14 / 05 / 1980$ & Box 25 \\
\hline Heusen, Van (1916 - 1990) & American Composer & 2 & $13 / 01 / 1963$ & Box 9 \\
\hline Hewitt, William (1951) & Scottish Minister & $\begin{array}{l}1 \\
1\end{array}$ & $\begin{array}{l}23 / 11 / 1965 \\
13 / 02 / 1982\end{array}$ & Box 25 \\
\hline Hiquily, Philippe (1925) & French Sculptor & 3 & 08/10/1961 & $\begin{array}{l}\text { Box } 25 \\
\text { Box } 73\end{array}$ \\
\hline Hirschfeld, Al (1903 - 2003) & American Cartoonist & $\begin{array}{l}3 \\
1 \\
2\end{array}$ & $\begin{array}{l}31 / 03 / 1983 \\
31 / 03 / 1984 \\
25 / 02 / 1997\end{array}$ & Box 26 \\
\hline Hirschfeld, Louise (Unknown) & Relation to Al Hirschfeld & 2 & $25 / 02 / 1997$ & Box 26 \\
\hline Hirshfield, Morris (1872 - 1946) & Polish American Painter & 2 & $1 / 10 / 1942$ & Box 26 \\
\hline Hirshhorn, Joseph (1899 -1981) & Latvian-American Art Collector & 8 & $06 / 12 / 1972$ & Box 26 \\
\hline Hockney, David (1937) & $\begin{array}{l}\text { English Painter, Printmaker and } \\
\text { Photographer }\end{array}$ & $\begin{array}{l}3 \\
1 \\
6\end{array}$ & $\begin{array}{l}12 / 05 / 1975 \\
29 / 05 / 1977 \\
29 / 05 / 1978\end{array}$ & \\
\hline Hoey, Clyde R. (1877 - 1954) & American Politician & 5 & $25 / 06 / 1953$ & Box 26 \\
\hline Hoffman, Julius J. (1895 - 1983) & American Judge & 1 & $13 / 01 / 1953$ & Box 26 \\
\hline Hofmann, Hans (1880 - 1966) & $\begin{array}{l}\text { German-American Painter and } \\
\text { Teacher }\end{array}$ & $\begin{array}{l}5 \\
1 \\
4\end{array}$ & $\begin{array}{l}01 / 09 / 1952 \\
14 / 08 / 1956 \\
21 / 08 / 1960\end{array}$ & Box 26 \\
\hline Holder, Geoffrey (1930) & $\begin{array}{l}\text { Trinidadian Director, Painter and } \\
\text { Singer }\end{array}$ & 5 & $12 / 03 / 1986$ & Box 26 \\
\hline Holm, Hanya (1893 - 1992) & $\begin{array}{l}\text { American Dancer, Choreographer } \\
\text { and Educator }\end{array}$ & 3 & $20 / 11 / 1956$ & Box 26 \\
\hline Holton, Gerald (1922) & German Physicist & 2 & $15 / 10 / 1959$ & Box 27 \\
\hline
\end{tabular}




\begin{tabular}{|c|c|c|c|c|}
\hline Hondius, Gerritt (1891 - 1970) & American Artist & 4 & $14 / 08 / 1964$ & $\begin{array}{l}\text { Box } 27 \\
\text { Oversized }\end{array}$ \\
\hline Hopkins, Budd (1931 - 2011) & American Painter and Sculptor & 4 & $05 / 09 / 1965$ & Box 27 \\
\hline Hopper, Edward (1882 - 1967) & American Painter & $\begin{array}{l}3 \\
3 \\
7\end{array}$ & $\begin{array}{l}01 / 11 / 1941 \\
01 / 11 / 1942 \\
14 / 08 / 1960\end{array}$ & Box 27 \\
\hline Hopper, Jo (1883 - 1968) & American Painter & 7 & $14 / 08 / 1960$ & $\begin{array}{l}\text { Box } 27 \\
\text { Oversized }\end{array}$ \\
\hline Horowitz, David (1939) & American Writer & 1 & $06 / 01 / 1981$ & Box 27 \\
\hline Horowitz, Norman (1915 - 2005) & American Geneticist & 1 & $11 / 08 / 1975$ & Box 37 \\
\hline Horowitz, Ryszard (1939) & Polish Photographer & 1 & $29 / 11 / 1995$ & Box 27 \\
\hline Hosoe, Eikoh (1933) & Japanese Photographer & 2 & $23 / 04 / 1991$ & Box 27 \\
\hline Houghton, Amory "Amo" Jr. (1926) & American Politician & 2 & $19 / 11 / 1965$ & Box 27 \\
\hline Houseman, John (1902 - 1988) & $\begin{array}{l}\text { British-American Actor and Film } \\
\text { Producer }\end{array}$ & 3 & $14 / 08 / 1974$ & Box 27 \\
\hline Hughes, Langston (1902 - 196) & American Poet & 2 & $29 / 01 / 1960$ & Box 27 \\
\hline Hume, Cardinal (1923 - 1990) & English Monk & 2 & $18 / 05 / 1978$ & Box 2 \\
\hline Hunt, Bryan (1947) & American Sculptor & 7 & $29 / 06 / 1983$ & $\begin{array}{l}\text { Box } 27 \\
\text { Box } 73\end{array}$ \\
\hline Hunt, James (1947 - 1993) & English Racing Driver & 1 & $03 / 06 / 1978$ & Oversized \\
\hline Hurok, Sol (1888 - 1974) & American Impresario & 2 & $20 / 12 / 1966$ & Box 27 \\
\hline Huszar, Tibor (1952) & Slovenian Photographer & $\begin{array}{l}1 \\
1\end{array}$ & $\begin{array}{l}23 / 11 / 1995 \\
14 / 12 / 1995\end{array}$ & Box 27 \\
\hline Indiana, Robert (1928) & American Painter and Sculptor & $\begin{array}{l}4 \\
2\end{array}$ & $\begin{array}{l}31 / 12 / 1971 \\
22 / 08 / 1993\end{array}$ & $\begin{array}{l}\text { Box } 27 \\
\text { Box } 73\end{array}$ \\
\hline Ingraham, Joe (1903 - 1990) & American Judge & 2 & $25 / 10 / 1956$ & Box 18 \\
\hline Irons, Jeremy (1948) & English Actor & 1 & $24 / 10 / 1985$ & $\begin{array}{l}\text { Box } 28 \\
\text { Box } 73\end{array}$ \\
\hline Jackson, Ann (1926) & American Actress & 2 & $\begin{array}{l}14 / 06 / 1961 \\
09 / 08 / 1984\end{array}$ & Box 63 \\
\hline Jaffe, Leo (1909 - 1997) & American Filmmaker & 2 & $06 / 08 / 1975$ & Box 26 \\
\hline Janis, Byron (1928) & American Pianist & 1 & $20 / 06 / 1963$ & Box 28 \\
\hline Janis, Sidney (1896 - 1989) & American Artist & 2 & $02 / 09 / 1943$ & Box 28 \\
\hline Javacheff, Christo Vladimirov (1935) & Bulgarian Environmental Artist & 2 & $02 / 04 / 1980$ & Box 11 \\
\hline Jemerin, Edward (1908 -1983) & American Scientist & 2 & $17 / 05 / 1969$ & Box 28 \\
\hline Jenkins, Alice & Spouse to Paul Jenkins & 6 & $18 / 06 / 1968$ & Box 28 \\
\hline Jenkins, Paul (1923) & American Painter & $\begin{array}{l}2 \\
7 \\
2 \\
1\end{array}$ & $\begin{array}{l}06 / 10 / 1956 \\
18 / 06 / 1968 \\
16 / 09 / 1977 \\
19 / 10 / 1978\end{array}$ & Box 28 \\
\hline Johns, Jasper (1930) & $\begin{array}{l}\text { American Painter, Sculptor and } \\
\text { Printmaker }\end{array}$ & 4 & $01 / 02 / 1980$ & Box 29 \\
\hline Johnson, Barbara (1947 - 2009) & American Literary Critic & 2 & $23 / 11 / 1975$ & Box 29 \\
\hline Johnson, Lyndon B. (1908 - 1973) & American President & $\begin{array}{l}2 \\
1 \\
7 \\
2\end{array}$ & $\begin{array}{l}12 / 07 / 1953 \\
29 / 07 / 1960 \\
19 / 12 / 1963 \\
10 / 01 / 1964\end{array}$ & Box 29 \\
\hline Johnson, Philip (1906 - 2005) & American Architect & $\begin{array}{l}10 \\
1\end{array}$ & $\begin{array}{l}01 / 07 / 1949 \\
26 / 01 / 1957\end{array}$ & $\begin{array}{l}\text { Box } 29 \\
\text { Oversized } \\
\text { Box } 83\end{array}$ \\
\hline
\end{tabular}




\begin{tabular}{|c|c|c|c|c|}
\hline & & & & Box 84 \\
\hline Jonas, Maryla (1911 - 1959) & Dutch Pianist & 2 & $24 / 09 / 1948$ & Box 29 \\
\hline Jones, Harold (1904 - 1992) & British Artist & 2 & $09 / 08 / 1974$ & Box 29 \\
\hline Jones, James (1921 - 1977) & American Author & 2 & 19/04/1961 & Box 29 \\
\hline Jones, Jim (1931 - 1978) & American Cult Leader & 1 & $01 / 11 / 1968$ & Box 29 \\
\hline Judd, Donald (1928 - 1994) & $\begin{array}{l}\text { American Sculptor, Painter and } \\
\text { Author }\end{array}$ & 4 & $15 / 09 / 1973$ & Box 29 \\
\hline Jules, Mervin (1912 - 1994) & American Artist & 1 & $01 / 09 / 1952$ & Box 29 \\
\hline Justine, Colette (1952) & Tunisian Artist & 1 & $23 / 02 / 1973$ & Box 11 \\
\hline Kadishman, Menashe (1932) & Israeli Sculptor and Painter & $\begin{array}{l}4 \\
2\end{array}$ & $\begin{array}{l}14 / 02 / 1970 \\
29 / 07 / 1986\end{array}$ & Box 29 \\
\hline Kahane, Meir (1932 - 1990) & $\begin{array}{l}\text { American-Israeli Rabbi, Writer and } \\
\text { Politician }\end{array}$ & 2 & $07 / 11 / 1971$ & Box 30 \\
\hline Kahn, Louis Isadore (1901 - 1974) & American Architect & 4 & $17 / 10 / 1964$ & Box 30 \\
\hline Kane, "Killer" & Fictional Character & 1 & $07 / 12 / 1959$ & Box 30 \\
\hline Kanovitz, Howard (1929 - 2009) & American Painter & 2 & $05 / 09 / 1963$ & Box 30 \\
\hline Kantor, Morris (1896 - 1974) & American Painter & 3 & $01 / 04 / 1944$ & Box 30 \\
\hline Kaplan, Jacques (1924 - 2008) & American Fashion Designer & 1 & $10 / 07 / 1966$ & Box 30 \\
\hline Kaplan, Joseph (1902 - 1991) & American Physicist & 2 & $01 / 08 / 1953$ & Box 30 \\
\hline Karloff, Boris (1887 - 1969) & English Actor & 1 & $2 / 11 / 1948$ & Box 30 \\
\hline Karp, Ivan (1926 - 2012) & $\begin{array}{l}\text { American Art Dealer, Author and } \\
\text { Gallerist }\end{array}$ & 2 & $26 / 09 / 1973$ & Box 30 \\
\hline Karp, Marilyn (Unknown) & Relation to Ivan Karp & 1 & $26 / 09 / 1973$ & Box 30 \\
\hline Katz, Alex (1927) & American Paint and Printmaker & 2 & $18 / 05 / 1993$ & Box 30 \\
\hline $\begin{array}{l}\text { Katzenbach, Nicholas de Belleville (1922 } \\
\text { - 2012) }\end{array}$ & American Lawyer & 1 & $01 / 02 / 1983$ & Box 30 \\
\hline Kaye, Danny (1913 - 1987) & American Actor & $\begin{array}{l}3 \\
3\end{array}$ & $\begin{array}{l}02 / 01 / 1949 \\
03 / 04 / 1968\end{array}$ & $\begin{array}{l}\text { Box } 30 \\
\text { Box } 73\end{array}$ \\
\hline Kazin, Alfred (1915 - 1998) & American Author & 4 & $25 / 04 / 1968$ & Box 30 \\
\hline Kelly, Ellsworth (1923) & American Painter and Sculptor & $\begin{array}{l}1 \\
5\end{array}$ & $\begin{array}{l}27 / 01 / 1980 \\
25 / 09 / 1992\end{array}$ & $\begin{array}{l}\text { Box } 30 \\
\text { Oversized }\end{array}$ \\
\hline Kennedy, David M. (1941) & American Historian & 1 & $30 / 01 / 1958$ & Box 30 \\
\hline Kennedy, John F. (1917 - 1963) & American President & $\begin{array}{l}5 \\
2 \\
1\end{array}$ & $\begin{array}{l}25 / 06 / 1953 \\
28 / 07 / 1960 \\
12 / 12 / 1961\end{array}$ & $\begin{array}{l}\text { Box } 30 \\
\text { Oversized }\end{array}$ \\
\hline Kepes, György (1906 - 2001) & Hungarian Painter & 3 & $04 / 09 / 1965$ & Box 30 \\
\hline Kertesz, Andre (1894 - 1985) & American Photographer & 3 & $15 / 01 / 1980$ & Box 31 \\
\hline Ketcham, Hank (1920 - 2001) & American Cartoonist & 1 & $08 / 11 / 1968$ & Box 31 \\
\hline Kienholz, Edward (1927 - 1994) & American Sculptor & 3 & $16 / 10 / 1967$ & Box 31 \\
\hline Kiesler, Frederick John (1890 - 1965) & $\begin{array}{l}\text { Austrian Architect, Sculptor and } \\
\text { Painter }\end{array}$ & 6 & $17 / 03 / 1962$ & $\begin{array}{l}\text { Box } 31 \\
\text { Oversized } \\
\text { Box } 73\end{array}$ \\
\hline Kimball, Fiske (1888 - 1955) & American Architect & 1 & $01 / 03 / 1951$ & Box 18 \\
\hline King, Phillip (1934) & British Sculptor & 6 & $24 / 06 / 1966$ & Box 31 \\
\hline Kinsey, Alfred (1894 - 1956) & American Biologist & 5 & $04 / 15 / 1948$ & $\begin{array}{l}\text { Box } 31 \\
\text { Box } 73\end{array}$ \\
\hline Kirby, Robert E. (1919 - 1999) & American Businessman & 2 & $18 / 10 / 1974$ & Box 31 \\
\hline Kirkpatrick, Jeane (1926 - 2006) & American Ambassador & 1 & $09 / 02 / 1981$ & Box 31 \\
\hline
\end{tabular}




\begin{tabular}{|c|c|c|c|c|}
\hline Kline, Franz (1910 - 1962) & American Painter & 5 & 19/08/1960 & Box 31 \\
\hline Knaths, Karl (1891 - 1971) & American Artist & 3 & $20 / 08 / 1960$ & Box 31 \\
\hline Knopf, Alfred (1892 - 1984) & American Publisher & 4 & $01 / 11 / 1949$ & $\begin{array}{l}\text { Box } 31 \\
\text { Box } 73\end{array}$ \\
\hline Knowles, John (1926 - 2001) & American Author & 1 & $06 / 02 / 1964$ & Box 31 \\
\hline Kolin, Oscar (1911 - 1995) & $\begin{array}{l}\text { Polish American Businessman and } \\
\text { Chemist }\end{array}$ & 1 & $01 / 09 / 1970$ & Box 31 \\
\hline Kolisch, Marian Wood (1920 - 2008) & American photographer & 1 & $13 / 11 / 1984$ & Box 31 \\
\hline Kollek, Teddy (1911 - 2007) & Israeli Politician & $\begin{array}{l}2 \\
2 \\
1 \\
1 \\
2\end{array}$ & $\begin{array}{l}10 / 05 / 1965 \\
01 / 12 / 1967 \\
20 / 04 / 1978 \\
08 / 05 / 1979 \\
30 / 05 / 1982\end{array}$ & Box 31 \\
\hline Koussevitzky, Madame Serge (Unknown) & Spouse to Serge Kousssevitzky & 3 & $18 / 01 / 1961$ & Box 32 \\
\hline Krasner, Lee (1908 - 1984) & American Painter & 4 & $18 / 09 / 1973$ & Box 32 \\
\hline Krock, Arthur (1886 - 1974) & American Journalist & 2 & $01 / 11 / 1951$ & Box 32 \\
\hline Kroll, Leon (1884 - 1974) & American Painter and Printmaker & $\begin{array}{l}1 \\
3\end{array}$ & $\begin{array}{l}01 / 06 / 1947 \\
11 / 02 / 1958\end{array}$ & Box 32 \\
\hline Krupp, Alfried (1907 - 1967) & Nazi War Criminal & 6 & 06/07/1963 & Box 32 \\
\hline Kuniyoshi, Yasuo (1889 - 1953) & $\begin{array}{l}\text { American Painter, Photographer and } \\
\text { Printmaker }\end{array}$ & 3 & 06/09/1941 & Box 32 \\
\hline Kupferman, Moshe (1926) & Israeli Painter & 5 & $24 / 05 / 1982$ & Box 32 \\
\hline Kurosawa, Akira (1910 - 1998) & Japanese Film Director & 3 & $07 / 10 / 1981$ & Box 32 \\
\hline Kuroyanagi, Tetsuko (1933) & Japanese Actress & 2 & $05 / 11 / 1995$ & Box 32 \\
\hline Kuzunuki, Ritsuko (1959 - 2004) & Japanese Singer and Songwriter & 2 & $20 / 06 / 1992$ & Box 32 \\
\hline La Parc, Julio (1928) & Argentine Painter & $\begin{array}{l}3 \\
4\end{array}$ & $\begin{array}{l}19 / 06 / 1966 \\
12 / 03 / 1967\end{array}$ & Box 32 \\
\hline LaGuerre, Andre (1915 - 1979) & American Journalist & 3 & $16 / 09 / 1972$ & Box 32 \\
\hline Lake and Palmer Emerson & English Rock and Roll Band & 3 & 28/04/1977 & Box 17 \\
\hline Laker, Sir Freddie (1922 - 2006) & British Businessman & 2 & $31 / 10 / 1978$ & $\begin{array}{l}\text { Box } 32 \\
\text { Oversized }\end{array}$ \\
\hline Land, Edwin H. (1909 - 1991) & American Scientist and Businessman & 2 & 09/02/1977 & Box 32 \\
\hline Lassaw, Ibram (1913 - 2003) & American Sculptor & 1 & $01 / 08 / 1953$ & Box 33 \\
\hline Laughlin, James (1914 - 1997) & American Poet & 1 & $01 / 11 / 1949$ & Box 33 \\
\hline Laurence, William (1888 - 1977) & American Journalist & 3 & $18 / 06 / 1946$ & Box 33 \\
\hline Lavin, Bernice (1925 - 2007) & $\begin{array}{l}\text { American Businesswoman and } \\
\text { Philanthropist }\end{array}$ & 1 & $05 / 02 / 1973$ & Box 33 \\
\hline Lawrence, Gwen (Unknown) & Relation to Jacob Lawrence & $\begin{array}{l}2 \\
4\end{array}$ & $\begin{array}{l}08 / 04 / 1944 \\
06 / 10 / 1987\end{array}$ & $\begin{array}{l}\text { Box } 33 \\
\text { Box } 73\end{array}$ \\
\hline Lawrence, Jacob (1917 - 2000) & American Painter & $\begin{array}{l}2 \\
4 \\
5\end{array}$ & $\begin{array}{l}08 / 04 / 1944 \\
29 / 03 / 1959 \\
06 / 10 / 1987\end{array}$ & $\begin{array}{l}\text { Box } 33 \\
\text { Box } 73\end{array}$ \\
\hline Ledoux, Jean Picard (1902 - 1982) & French Painter & 2 & Unknown & $\begin{array}{l}\text { Box } 28 \\
\text { Box } 73\end{array}$ \\
\hline Lee, Gypsy Rose (1911 - 1970) & American Dancer, Entertainer & 4 & $07 / 09 / 1945$ & Box 33 \\
\hline Leger, Cardinal Paul (1904 - 1991) & Canadian Cardinal & 2 & $17 / 09 / 1963$ & Box 34 \\
\hline Leger, Fernand (1881 - 1955) & French Painter & 5 & $07 / 10 / 1941$ & Box 34 \\
\hline
\end{tabular}




\begin{tabular}{|c|c|c|c|c|}
\hline Lehman, Herbert (1878 - 1963) & American Politician & 3 & $14 / 07 / 1953$ & Box 34 \\
\hline Leibman, Max (1902 - 1982) & American Producer and Director & 1 & $27 / 10 / 1955$ & Box 34 \\
\hline Leigh, Janet (1927 - 2004) & American Actress and Author & 1 & $07 / 09 / 1948$ & Box 34 \\
\hline Leighton, Margaret (1922 - 1976) & English Actress & 1 & $03 / 04 / 1968$ & Box 34 \\
\hline Leinsdorf, Erich (1912 - 1993) & Austrian-American Conductor & $\begin{array}{l}1 \\
1\end{array}$ & $\begin{array}{l}04 / 04 / 1956 \\
20 / 04 / 1956\end{array}$ & Box 34 \\
\hline Lelong, Lucien (1889 - 1958) & French Couturier & 1 & $23 / 01 / 1942$ & Box 34 \\
\hline Lettvin, Jerry (1920 - 2011) & American Scientist & 1 & $15 / 09 / 1970$ & Box 34 \\
\hline Levi, Carlo (1902 - 1975) & Italian Painter, Writer and Activist & 1 & $05 / 06 / 1954$ & $\begin{array}{l}\text { Box } 34 \\
\text { Box } 73\end{array}$ \\
\hline Levi, Julian E. (1900 - 1982) & American Painter & 3 & $16 / 01 / 1942$ & Box 34 \\
\hline Levine, Jack (1915 - 2010) & American Painter & 8 & $1 / 15 / 1942$ & Box 34 \\
\hline Levinson, Mon (1926) & American Artist & 4 & $29 / 07 / 1969$ & Box 34 \\
\hline Levitt, Helen (1913 - 2009) & American Photographer & 2 & $13 / 04 / 1944$ & Box 34 \\
\hline Levy, Norman (1931 - 1998) & American Politician and Lawyer & 1 & $18 / 08 / 1975$ & Box 34 \\
\hline Lewis, Norman (1908 - 2003) & British Author & 1 & $05 / 02 / 1960$ & Box 34 \\
\hline Lewis, Tillie Ehrlich (1901 - 1977) & American Businesswoman & 2 & $08 / 02 / 1973$ & Box 34 \\
\hline Libchaber, Dr. Albert (1934) & American Physicist & 2 & $01 / 12 / 1995$ & Box 34 \\
\hline Licade, Cecile (1961) & Filipina Pianist & 2 & $02 / 05 / 1983$ & Box 1 \\
\hline Lichtenstein, Roy (1923 - 1997) & $\begin{array}{l}\text { American Painter, Sculptor and } \\
\text { Printmaker }\end{array}$ & 4 & $18 / 09 / 1976$ & Box 34 \\
\hline Lieberson, Goddard (1956 - 1971) & American Businessman & 2 & 28/10/1957 & Box 34 \\
\hline Lilienthal, David (1899 - 1981) & American Politician & $\begin{array}{l}2 \\
1\end{array}$ & $\begin{array}{l}03 / 01 / 1948 \\
11 / 02 / 1963\end{array}$ & $\begin{array}{l}\text { Box } 35 \\
\text { Box } 73\end{array}$ \\
\hline Lindner, Richard (1901 - 1978) & American Painter & 11 & 05/03/1977 & Box 35 \\
\hline Lipchitz, Jacques (1891 - 1973) & French Sculptor & $\begin{array}{l}2 \\
2\end{array}$ & $\begin{array}{l}10 / 09 / 1942 \\
11 / 10 / 1946\end{array}$ & Box 35 \\
\hline Lippman, Walter (1889 - 1974) & American Writer and Journalist & 1 & $01 / 02 / 1960$ & Box 35 \\
\hline Lipton-Shahak, Amnon (1944 - 2012) & Israeli Politician & 1 & $14 / 01 / 1994$ & Box 54 \\
\hline Logan, Joshua (1908 - 1988) & American Actor & 1 & $24 / 03 / 1978$ & Box 35 \\
\hline Logan, Nedda (1945-1988) & Spouse to Joshua Logan & 1 & $24 / 03 / 1978$ & Box 35 \\
\hline Lombardo, Joseph (1929) & American Mafioso & 1 & $12 / 12 / 1972$ & Box 35 \\
\hline London, Ephraim (1912 - 1990) & American Lawyer & 2 & $27 / 07 / 1960$ & Box 35 \\
\hline Longworth, Alice (Unknown) & Spouse to Nichols Longworth & 1 & $20 / 04 / 1948$ & Box 35 \\
\hline $\begin{array}{l}\text { Longworth, Alice Roosevelt (1884 - } \\
\text { 1980) }\end{array}$ & American Socialite & 1 & $4 / 20 / 1948$ & Box 35 \\
\hline Lowe, Ira (1924 - 2012) & American Lawyer & 2 & $19 / 01 / 1984$ & Box 35 \\
\hline Luce, Henry (1898 - 1967) & American Publisher & 4 & $30 / 01 / 1962$ & Box 35 \\
\hline Lynn, Dame Vera (1917) & English Singer and Dancer & 1 & 03/11/1978 & Box 35 \\
\hline $\begin{array}{l}\text { Maclean, Charles Hector Fitzroy (1916 - } \\
\text { 1990) }\end{array}$ & Scottish Clan Chief & 2 & $09 / 04 / 1954$ & Box 36 \\
\hline MacLeish, Archibald (1892 - 1982) & American Poet & $\begin{array}{l}3 \\
1\end{array}$ & $\begin{array}{l}26 / 01 / 1953 \\
28 / 04 / 1959\end{array}$ & Box 36 \\
\hline Mailer, Norman (1923 - 2007) & $\begin{array}{l}\text { American Novelist, Journalist, } \\
\text { Playwright and Filmmaker }\end{array}$ & $\begin{array}{l}2 \\
5\end{array}$ & $\begin{array}{l}01 / 09 / 1952 \\
22 / 08 / 1964\end{array}$ & Box 36 \\
\hline Mansfield, Michael (1941) & English Lawyer & 1 & $14 / 11 / 1961$ & Box 36 \\
\hline Mansfield, Mike (1903 - 2001) & American Politician and Diplomat & 1 & $29 / 12 / 1961$ & Box 36 \\
\hline Manso, Leo (1914 - 1993) & American Artist & 5 & $01 / 08 / 1953$ & Box 36 \\
\hline Marantz, Irving (1912 - 1972) & American Artist & 1 & $01 / 09 / 1952$ & Box 36 \\
\hline
\end{tabular}




\begin{tabular}{|c|c|c|c|c|}
\hline Marcks, Gerhard (1889 - 1981) & $\begin{array}{l}\text { German Sculptor, Draftsman and } \\
\text { Printmaker }\end{array}$ & 1 & $02 / 06 / 1950$ & Box 36 \\
\hline Marcus, Stanley (1905 - 2002) & American Businessman & 1 & $17 / 01 / 1957$ & Box 36 \\
\hline Margolin, Janet (1943 - 1993) & American Actress & 1 & $11 / 03 / 1964$ & Box 36 \\
\hline Margules, De Hirsh (1899 - 1965) & American Painter & 1 & $19 / 09 / 1943$ & Box 36 \\
\hline Marin, John $(1872$ - 1953) & American Painter and Etcher & 5 & $11 / 02 / 1947$ & Box 37 \\
\hline Marini, Marino (1901 - 1980) & Italian Sculptor & 5 & $01 / 02 / 1950$ & Box 37 \\
\hline Mark, Mary Ellen (1941) & American Photographer & $\begin{array}{l}2 \\
2\end{array}$ & $\begin{array}{l}18 / 08 / 1992 \\
18 / 08 / 1993\end{array}$ & Box 37 \\
\hline Markel, Lester (1894 - 1977) & American Journalist & 1 & $06 / 01 / 1956$ & Box 37 \\
\hline Marsalis, Wynton (1961) & American Musician & 2 & 07/10/1999 & Box 66 \\
\hline Marsh, Reginald (1898 - 1954) & American Painter & 5 & 05/09/1941 & Box 37 \\
\hline Marshall, Thurgood (1908 -1993) & American Justice & 2 & $01 / 02 / 1960$ & Box 37 \\
\hline Martin, Fletcher (1904 - 1979) & $\begin{array}{l}\text { American Watercolourist and } \\
\text { Muralist }\end{array}$ & 2 & $10 / 09 / 1943$ & Box 37 \\
\hline Marzel, Baruch Meir (Unknown) & American/Israeli Politician & 1 & $12 / 01 / 1994$ & Box 37 \\
\hline Masina, Giulietta (1921 - 1994) & Italian Actress & 1 & $03 / 04 / 1968$ & Box 37 \\
\hline Masket, Ed (1923 - 2011) & American Businessman & 1 & $11 / 08 / 1975$ & Box 37 \\
\hline Mason, James (1909 - 1984) & English Actor & 2 & $9 / 12 / 1946$ & $\begin{array}{l}\text { Box } 37 \\
\text { Box } 74\end{array}$ \\
\hline Masson, Andre (1896 - 1987) & French Painter and Author & 1 & $23 / 11 / 1959$ & $\begin{array}{l}\text { Box } 2 \\
\text { Box } 78\end{array}$ \\
\hline Mathieu, Georges (1921) & $\begin{array}{l}\text { French Painter, Sculptor, Designer } \\
\text { and Illustrator }\end{array}$ & 2 & $12 / 05 / 1954$ & Box 37 \\
\hline Matta, Roberto (1911 - 2002) & Chilean Painter and Printmaker & 7 & $05 / 01 / 1960$ & Box 37 \\
\hline Matta, Sebastian Echaurren (1911 - 2002) & Chilean Painter and Printmaker & 7 & $01 / 05 / 1960$ & Box 37 \\
\hline Maybank, Burnet R. (1899 - 1954) & American Politician & 2 & $01 / 12 / 1951$ & Box 37 \\
\hline Mayer, Jules (Unknown) & American Artist & 2 & $18 / 10 / 1971$ & Box 37 \\
\hline Maynard, Frederick C. Jr. (1922 - 1997) & American Businessman & 2 & $08 / 01 / 1975$ & Box 38 \\
\hline McArdell, Archie (1926 - 2008) & American Businessman & 1 & $19 / 11 / 1973$ & Box 38 \\
\hline McCabe, Thomas B. (1893 - 1982) & American Politician & 2 & $28 / 01 / 1955$ & Box 38 \\
\hline McCarthy, Joseph R. (1908 - 1957) & American Senator & 2 & $14 / 07 / 1953$ & Box 38 \\
\hline McCormick, Anne O'Hare (1880 - 1954) & American Journalist & 2 & $25 / 11 / 1953$ & Box 38 \\
\hline McGeorge, Bundy (1919 - 1996) & American National Security Advisor & 1 & $09 / 07 / 1965$ & Box 7 \\
\hline McGhee, Alan (1960) & American Music Label Owner & 2 & $10 / 08 / 1990$ & Box 38 \\
\hline McGovern, George (1922 - 2012) & American Author and Politician & 2 & $21 / 01 / 1975$ & Box 38 \\
\hline McIlhenny, Henry P. (1910 - 1986) & $\begin{array}{l}\text { American Art Collector, } \\
\text { Philanthropist and Museum Director }\end{array}$ & 3 & $24 / 03 / 1973$ & Box 36 \\
\hline McNamara, Robert (1916 - 2009) & American Secretary of Defense & 1 & $12 / 07 / 1965$ & Box 38 \\
\hline Mehta, Ved (1934) & Indian Writer & 1 & $08 / 04 / 1960$ & Box 38 \\
\hline Meier, Richard (1934) & American Architect & $\begin{array}{l}2 \\
1\end{array}$ & $\begin{array}{l}19 / 12 / 1975 \\
21 / 09 / 1999\end{array}$ & Box 38 \\
\hline Meir, Golda (1898 - 1978) & Israeli Prime Minister & 3 & $22 / 06 / 1970$ & Box 38 \\
\hline $\begin{array}{l}\text { Melish, Rev. William Howard (1910 - } \\
\text { 1986) }\end{array}$ & Unknown Priest & 3 & $16 / 04 / 1972$ & Box 38 \\
\hline Mellon, Paul (1907 - 1999) & American Philanthropist & 1 & $24 / 02 / 1992$ & Box 38 \\
\hline
\end{tabular}




\begin{tabular}{|c|c|c|c|c|}
\hline Melnicker, Benjamin (Unknown) & American Film Director & 1 & $08 / 01 / 1969$ & Box 38 \\
\hline Mercouri, Melina (1920 - 1994) & Greek Actress and Politician & 1 & $10 / 01 / 1983$ & Box 38 \\
\hline Merrick, David (1911 - 2000) & American Theatre Producer & 2 & $11 / 01 / 1961$ & Box 38 \\
\hline Merrill, Dina (1925) & American Actress & $\begin{array}{l}2 \\
1\end{array}$ & $\begin{array}{l}05 / 06 / 1974 \\
08 / 09 / 1982\end{array}$ & Box 38 \\
\hline Meyerowitz, Joel (1938) & American Photographer & 2 & 26/05/1993 & Box 38 \\
\hline Michals, Duane (1932) & American Photographer & $\begin{array}{l}5 \\
7\end{array}$ & $\begin{array}{l}29 / 05 / 1977 \\
27 / 08 / 1986\end{array}$ & $\begin{array}{l}\text { Box } 39 \\
\text { Box } 74\end{array}$ \\
\hline Middelton, Drew (1914 - 1990) & American Journalist & 1 & $01 / 05 / 1954$ & Box 39 \\
\hline Miller, Arthur (1915 - 2005) & American Playwright and Essayist & $\begin{array}{l}1 \\
2 \\
3\end{array}$ & $\begin{array}{l}20 / 02 / 1947 \\
17 / 04 / 1947 \\
20 / 01 / 1962\end{array}$ & Box 39 \\
\hline Miller, Henry (1891 - 1980) & American Writer and Painter & 5 & $17 / 04 / 1976$ & $\begin{array}{l}\text { Box } 39 \\
\text { Box } 74\end{array}$ \\
\hline Miller, Lee (1907 - 1977) & American Photographer & 1 & $25 / 04 / 1975$ & Box 46 \\
\hline Minkkinen, Arno Rafael (1945) & Finnish Photographer & 1 & Unknown & Box 39 \\
\hline Miriani, Louis (1897 - 1987) & American Politician & 1 & $19 / 07 / 1960$ & Box 39 \\
\hline Miro, Joan (1893 - 1983) & $\begin{array}{l}\text { Spanish Painter, Printmaker and } \\
\text { Ceramicist }\end{array}$ & $\begin{array}{l}3 \\
7\end{array}$ & $\begin{array}{l}27 / 09 / 1947 \\
22 / 03 / 1979\end{array}$ & $\begin{array}{l}\text { Box } 39 \\
\text { Box } 74\end{array}$ \\
\hline Mitchell, Jan (1940 - 2008) & Australian Artist & 1 & $27 / 11 / 1954$ & Box 39 \\
\hline Model, Lisette (1901 - 1983) & American Photographer & 4 & 19/06/1980 & Box 39 \\
\hline Modica, Andrea (1960) & American Photographer & 2 & $03 / 03 / 2004$ & Box 39 \\
\hline Mondrian, Piet (1872 - 1944) & Dutch Painter & 9 & $17 / 01 / 1942$ & $\begin{array}{l}\text { Box } 40 \\
\text { Oversized }\end{array}$ \\
\hline Monroe, Marilyn (1926 - 1962) & American Actress & $\begin{array}{l}1 \\
18\end{array}$ & $\begin{array}{l}09 / 11 / 1961 \\
20 / 01 / 1962\end{array}$ & Box 40 \\
\hline Moore, Henry (1898 - 1986) & English Sculptor & $\begin{array}{l}5 \\
6 \\
6 \\
13\end{array}$ & $\begin{array}{l}17 / 09 / 1947 \\
25 / 06 / 1966 \\
22 / 10 / 1977 \\
27 / 10 / 1978\end{array}$ & $\begin{array}{l}\text { Box } 40 \\
\text { Box } 74\end{array}$ \\
\hline Moreell, Ben (1892 - 1978) & American Admiral & 1 & $11 / 12 / 1952$ & Box 41 \\
\hline $\begin{array}{l}\text { Morrison, Rt. Hon. Herbert Stanley (1888 } \\
-1965)\end{array}$ & British Politician & 1 & $01 / 03 / 1954$ & Box 41 \\
\hline Morrison, Stanley (1889 - 1967) & British Typographer & 1 & $01 / 03 / 1954$ & Box 41 \\
\hline Morse, Wayne (1900 - 1974) & American Politician & 2 & $09 / 07 / 1953$ & Box 41 \\
\hline Moses, Grandma (1960 - 1961) & American Painter & 6 & $01 / 10 / 1949$ & Box 41 \\
\hline Moses, Robert (1888 - 1981) & American Urban Planner & $\begin{array}{l}1 \\
4\end{array}$ & $\begin{array}{l}04 / 06 / 1959 \\
08 / 04 / 1964\end{array}$ & Box 41 \\
\hline Moskin, Robert (Unknown) & American Author & 1 & 28/03/1986 & Box 41 \\
\hline Moskowitz, Robert (1935) & American Painter & 2 & $05 / 01 / 1990$ & Box 41 \\
\hline Moss, Stirling (1929) & English Racing Driver & 1 & $03 / 06 / 1978$ & Oversized \\
\hline Mostel, Zero (1915 - 1977) & American Actor & 5 & $14 / 12 / 1962$ & Box 41 \\
\hline Motherwell, Robert (1915 - 1991) & $\begin{array}{l}\text { American Painter, Printmaker and } \\
\text { Author }\end{array}$ & $\begin{array}{l}4 \\
2 \\
\end{array}$ & $\begin{array}{l}27 / 03 / 1959 \\
23 / 08 / 1980\end{array}$ & Box 41 \\
\hline Mott, Nevill Francis (1905 - 1996) & English Physician & 1 & $19 / 05 / 1978$ & Oversized \\
\hline Mountbatten, Lord Louis (1900 - 1979) & British Statesman & 1 & $16 / 06 / 1978$ & Box 41 \\
\hline Mumford, Lewis (1895 - 1990) & American Historian & 3 & $03 / 02 / 1959$ & Box 41 \\
\hline Murdoch, Iris (1919 - 1999) & Irish Author and Philosopher & 2 & $07 / 06 / 1978$ & Box 41 \\
\hline Murdoch, Rupert (1931) & Australian-American Businessman & 2 & $31 / 01 / 1977$ & Box 41 \\
\hline
\end{tabular}




\begin{tabular}{|c|c|c|c|c|}
\hline Murphy, Thomas F. (1905 - 1995) & American Judge & 2 & $16 / 01 / 1951$ & Box 41 \\
\hline Murray, Lionel (1922 - 2004) & British Politician & 1 & $25 / 05 / 1978$ & Oversized \\
\hline Murrow, Edward R. (1908 - 1965) & American Journalist & 3 & $17 / 10 / 1951$ & Box 41 \\
\hline Mydans, Carl (1907 - 2004) & American Photographer & 1 & 27/01/1997 & Box 42 \\
\hline Mydans, Shelley (1915 - 2002) & American Author and Photographer & 1 & 27/01/1997 & Box 42 \\
\hline Nabokov, Vladimir (1899 - 1977) & Russian-American Novelist & 1 & $18 / 10 / 1968$ & Box 42 \\
\hline Navasky, Victor Saul (1932) & American Journalist & 2 & Unknown & Box 42 \\
\hline Neleman, Hans (1960) & Dutch Photographer & 2 & $18 / 10 / 1988$ & Box 42 \\
\hline Nelson, George (1908 - 1986) & American Architect and Designer & 3 & $06 / 01 / 1960$ & Box 42 \\
\hline Netanyahu, Benjamin (1949) & Israeli Politician & 2 & $26 / 04 / 1998$ & Box 42 \\
\hline Nevelson, Louise (1899 - 1988) & American Sculptor & $\begin{array}{l}9 \\
1\end{array}$ & $\begin{array}{l}29 / 08 / 1972 \\
17 / 08 / 1980\end{array}$ & $\begin{array}{l}\text { Box } 42 \\
\text { Box } 74\end{array}$ \\
\hline Newhall, Beaumont (1908 - 1993) & American Photographer and Curator & $\begin{array}{l}2 \\
2 \\
2\end{array}$ & $\begin{array}{l}01 / 10 / 1941 \\
27 / 02 / 1983 \\
20 / 07 / 1992\end{array}$ & Box 42 \\
\hline Newman, Arnold (1918 - 2006) & American Photographer & $\begin{array}{l}3 \\
3 \\
3 \\
1 \\
1 \\
1 \\
1 \\
1 \\
2 \\
1 \\
1 \\
2 \\
3 \\
1 \\
2 \\
1 \\
1 \\
1 \\
1 \\
1 \\
1 \\
1 \\
1 \\
1 \\
1 \\
1\end{array}$ & $\begin{array}{l}08 / 12 / 1941 \\
10 / 09 / 1945 \\
21 / 07 / 1954 \\
10 / 08 / 1957 \\
01 / 05 / 1960 \\
01 / 09 / 1962 \\
17 / 09 / 1964 \\
05 / 09 / 1968 \\
29 / 07 / 1969 \\
06 / 08 / 1971 \\
23 / 12 / 1972 \\
12 / 01 / 1973 \\
08 / 10 / 1976 \\
29 / 03 / 1978 \\
16 / 08 / 1979 \\
20 / 09 / 1979 \\
04 / 01 / 1983 \\
02 / 07 / 1984 \\
19 / 10 / 1987 \\
30 / 06 / 1992 \\
15 / 06 / 1993 \\
11 / 07 / 1993 \\
15 / 07 / 1998 \\
29 / 10 / 1998 \\
15 / 03 / 1999\end{array}$ & $\begin{array}{l}\text { Box } 42 \\
\text { Box } 43\end{array}$ \\
\hline Newman, Barnett (1904 - 1970) & American Artist & 7 & $06 / 02 / 1970$ & Box 43 \\
\hline Ney, Edward N. (1925) & $\begin{array}{l}\text { American Businessman and } \\
\text { Ambassador }\end{array}$ & 4 & $25 / 04 / 1977$ & Box 43 \\
\hline Nixon, Richard M. (1913 - 1994) & American President & $\begin{array}{l}3 \\
5 \\
1 \\
1\end{array}$ & $\begin{array}{l}11 / 07 / 1953 \\
28 / 09 / 1953 \\
16 / 07 / 1956 \\
07 / 02 / 1964\end{array}$ & Box 43 \\
\hline Nkrumah, Kwame (1909 - 1972) & Ghanaian Politician & 1 & $19 / 10 / 1958$ & Box 32 \\
\hline Noguchi, Isamu (1904 - 1988) & American Sculptor and Designer & $\begin{array}{l}4 \\
4\end{array}$ & $\begin{array}{l}04 / 07 / 1947 \\
10 / 03 / 1986\end{array}$ & Box 43 \\
\hline
\end{tabular}




\begin{tabular}{|c|c|c|c|c|}
\hline Norman, Dorothy (1905 - 1997) & American Photographer & 3 & $04 / 12 / 1975$ & Box 44 \\
\hline Nunn, Trevor (1940) & English Theatre and Film Director & 3 & $01 / 06 / 1978$ & $\begin{array}{l}\text { Box } 24 \\
\text { Oversized }\end{array}$ \\
\hline O'Doherty, Brian (1934) & American-Irish Sculptor and Author & 3 & $10 / 10 / 1983$ & Box 44 \\
\hline O'Keeffe, Georgia (1887 - 1986) & American Painter & $\begin{array}{l}6 \\
9\end{array}$ & $\begin{array}{l}17 / 04 / 1944 \\
02 / 08 / 1968\end{array}$ & $\begin{array}{l}\text { Box } 44 \\
\text { Box } 58 \\
\text { Oversized }\end{array}$ \\
\hline Oldenburg, Claes (1929) & $\begin{array}{l}\text { American Sculptor, Draftsman and } \\
\text { Printmaker }\end{array}$ & $\begin{array}{l}3 \\
1 \\
1\end{array}$ & $\begin{array}{l}15 / 10 / 1967 \\
27 / 09 / 1969 \\
14 / 04 / 1988\end{array}$ & $\begin{array}{l}\text { Box } 44 \\
\text { Oversized }\end{array}$ \\
\hline Olitski, Jules (1922 - 2007) & American Painter and Sculptor & 2 & $27 / 12 / 1978$ & Box 44 \\
\hline Olivier, Laurence Kerr (1907 - 1989) & British Actor & 2 & $14 / 06 / 1978$ & Box 44 \\
\hline Ollman, Arthur (1947) & American Photographer & $\begin{array}{l}1 \\
1\end{array}$ & $\begin{array}{l}17 / 02 / 1986 \\
05 / 06 / 1986\end{array}$ & Box 44 \\
\hline O'Neill, Eugene (1888 - 1953) & American Playwright & 8 & $10 / 12 / 1946$ & $\begin{array}{l}\text { Box } 44 \\
\text { Box } 74 \\
\text { Box } 82\end{array}$ \\
\hline Opel, John (1925 - 2011) & American Businessman & 1 & $31 / 01 / 1983$ & Box 45 \\
\hline Oppenheimer, Robert (1904 - 1967) & American Physicist & 4 & $06 / 06 / 1948$ & Box 45 \\
\hline Ormandy, Eugene (1899 - 1985) & Hungarian Conductor & 1 & $10 / 12 / 1959$ & Box 45 \\
\hline Osheroff, Douglas (1945) & American Scientist & 1 & $13 / 08 / 1984$ & Box 45 \\
\hline Owens, Robert (1961) & American Musician & $\begin{array}{l}1 \\
1\end{array}$ & $\begin{array}{l}12 / 07 / 1972 \\
29 / 10 / 1978\end{array}$ & Box 45 \\
\hline Ozenfant, Amédée (1886 - 1966) & French Painter & 1 & $01 / 14 / 1942$ & Box 45 \\
\hline Palade, George E. (1912 - 2008) & Romanian Cell Biologist & 2 & 19/06/1964 & Box 45 \\
\hline Paley, William S. (1901 - 1990) & American Businessman & $\begin{array}{l}2 \\
2\end{array}$ & $\begin{array}{l}02 / 01 / 1949 \\
12 / 03 / 1959\end{array}$ & Box 45 \\
\hline Palmer, Edward L. & American Author and Educator & 1 & $24 / 06 / 1976$ & Box 45 \\
\hline Papp, Joseph (1921 - 1991) & American Producer and Director & 2 & $17 / 01 / 1968$ & Box 45 \\
\hline Parks, Gordon (1912 - 2006) & $\begin{array}{l}\text { American Photographer, Writer, Film } \\
\text { Director }\end{array}$ & 3 & $16 / 06 / 1992$ & Box 45 \\
\hline Parmeggiani, Tancredi (1927 - 1964) & Italian Painter & 2 & $08 / 07 / 1954$ & Box 59 \\
\hline Parrott, Alice Kagawa (1929 - 2009) & Mexican/American Textile Artist & 2 & $04 / 02 / 1977$ & Box 45 \\
\hline Parsons, Estelle (1927) & American Actress & 1 & $09 / 04 / 1971$ & Box 45 \\
\hline Patterson, Alicia (1906 - 1963) & American Editor & 2 & $19 / 03 / 1962$ & Box 45 \\
\hline Paulus, Stephen (1949) & American Composer & 1 & $11 / 07 / 1994$ & Box 45 \\
\hline Pei, Ieoh Ming (1917) & Chinese-American Architect & 8 & $23 / 09 / 1967$ & Box 46 \\
\hline Penrose, Sir Rolan (1900 - 1984) & English Artist, Historian and Poet & 1 & $25 / 04 / 1975$ & Box 46 \\
\hline Penzias, Arno (1933) & American Physicist & 3 & $20 / 02 / 1985$ & Box 46 \\
\hline Peres, Shimon (1923) & Israeli Politician & 2 & $07 / 05 / 1979$ & $\begin{array}{l}\text { Box } 46 \\
\text { Box } 74\end{array}$ \\
\hline Phillips, Anne (Unknown) & Daughter to Anne Tandy & $\begin{array}{l}1 \\
3\end{array}$ & $\begin{array}{l}15 / 10 / 1973 \\
16 / 10 / 1973\end{array}$ & Box 59 \\
\hline Phillips, Warren (1954) & American Teacher & 1 & $24 / 06 / 1980$ & Box 46 \\
\hline Piatigorsky, Gregor (1903 - 1976) & Russian-American Cellist & 1 & 28/07/1971 & Box 46 \\
\hline Picasso, Pablo (1881 - 1973) & $\begin{array}{l}\text { Spanish Painter, Sculptor, Printmaker } \\
\text { and Ceramicist }\end{array}$ & $\begin{array}{l}20 \\
4\end{array}$ & $\begin{array}{l}02 / 06 / 1954 \\
11 / 09 / 1956\end{array}$ & $\begin{array}{l}\text { Box } 46 \\
\text { Oversized }\end{array}$ \\
\hline Picasso, Sara & Relation of Pablo Picasso & 1 & $14 / 09 / 1973$ & Box 46 \\
\hline
\end{tabular}




\begin{tabular}{|c|c|c|c|c|}
\hline Pinter, Harold (1930 - 2008) & English Playwright & 2 & $08 / 06 / 1978$ & $\begin{array}{l}\text { Box } 46 \\
\text { Oversized }\end{array}$ \\
\hline Pippin, Horace (1888 - 1946) & American Painter & 5 & $04 / 06 / 1945$ & Box 46 \\
\hline Pleasance, Donald (1919 - 1995) & English Actor & 1 & $03 / 04 / 1968$ & Box 46 \\
\hline Podhoretz, Norman (1930) & American Journalist & $\begin{array}{l}2 \\
2\end{array}$ & $\begin{array}{l}07 / 02 / 1972 \\
23 / 01 / 1980\end{array}$ & Box 46 \\
\hline Pollack, Peter (1941) & South African Cricket Player & 2 & $19 / 01 / 1961$ & Box 47 \\
\hline Pollock, Jackson (1912 - 1956) & American Painter & 9 & $03 / 01 / 1949$ & $\begin{array}{l}\text { Box } 47 \\
\text { Oversized }\end{array}$ \\
\hline Pollock, Sam (1925 - 2007) & American Hockey Manager & 2 & 29/03/1977 & Box 47 \\
\hline Pope-Hennessy, Sir John (1913 - 1994) & $\begin{array}{l}\text { British Art Historian and Museum } \\
\text { Director }\end{array}$ & 1 & $21 / 03 / 1978$ & Oversized \\
\hline Porter, Sylvia (1913 - 1991) & American Economist & $\begin{array}{l}2 \\
2\end{array}$ & $\begin{array}{l}17 / 09 / 1957 \\
13 / 03 / 1962\end{array}$ & Box 47 \\
\hline Powell, Adam Clayton (1908 - 1972) & American Politician and Pastor & 2 & $01 / 02 / 1960$ & Box 47 \\
\hline Powell, Charles (1941) & English Politician & 1 & $12 / 08 / 1975$ & Box 47 \\
\hline Powell, Enoch (1912 - 1998) & British Politician & 1 & $09 / 05 / 1978$ & Oversized \\
\hline Priebe, Karl (1914 - 1976) & American Painter & 1 & $10 / 14 / 1947$ & Box 47 \\
\hline Priestley, John Boynton (1894 - 1984) & English Novelist and Broadcaster & 3 & $15 / 06 / 1978$ & Box 47 \\
\hline Quant, Mary (1934) & British Fashion Designer & 1 & $07 / 06 / 1978$ & Box 47 \\
\hline Rabin, Yitzhak (1922 - 1995) & Israeli Politician & 1 & $11 / 01 / 1994$ & Box 47 \\
\hline Rambert, Dame Marie (1888 - 1982) & Polish Dancer & 1 & $08 / 05 / 1978$ & Oversized \\
\hline Rand, Ayn (1905 - 1982) & $\begin{array}{l}\text { Russian-American Novelist and } \\
\text { Playwright }\end{array}$ & $\begin{array}{l}1 \\
6\end{array}$ & $\begin{array}{l}14 / 09 / 1964 \\
15 / 09 / 1964\end{array}$ & Box 48 \\
\hline Raskin, Abe (1911 - 1993) & American Journalist & 2 & $20 / 07 / 1953$ & Box 48 \\
\hline Rattner, Abraham (1893 - 1978) & American Painter and Designer & 2 & $03 / 04 / 1944$ & Box 48 \\
\hline Rauscheberg, Robert (1925 - 2008) & $\begin{array}{l}\text { American Painter, Sculptor and } \\
\text { Photographer }\end{array}$ & $\begin{array}{l}12 \\
1\end{array}$ & $\begin{array}{l}09 / 05 / 1977 \\
17 / 05 / 1977\end{array}$ & Box 48 \\
\hline Rawleigh, Warner Jr. (1921 - 2013) & American Businessman & $\begin{array}{l}1 \\
1 \\
1 \\
1\end{array}$ & $\begin{array}{l}12 / 11 / 1973 \\
11 / 12 / 1978 \\
17 / 01 / 1979 \\
24 / 01 / 1980\end{array}$ & Box 63 \\
\hline Ray, Man (1890 - 1976) & American Painter and Photographer & $\begin{array}{l}2 \\
6\end{array}$ & $\begin{array}{l}13 / 06 / 1948 \\
01 / 05 / 1960\end{array}$ & $\begin{array}{l}\text { Box } 48 \\
\text { Box } 74\end{array}$ \\
\hline Reagan, Ronald (1911 - 2004) & American President & 2 & $14 / 12 / 1981$ & Box 50 \\
\hline Rears, Sir Peter (1910 - 1986) & English Singer & 2 & $23 / 10 / 1978$ & Box 48 \\
\hline Rees-Mogg, William (1928 - 2012) & English Journalist & 2 & $06 / 12 / 1979$ & Box 24 \\
\hline Reid, Ogden R. (1925) & United States Ambassador & 2 & $01 / 08 / 1959$ & Box 28 \\
\hline Reston, James (1909 - 1995) & American Journalist & 2 & $01 / 11 / 1951$ & Box 48 \\
\hline Reuther, Walter (1907 - 1970) & American Politician & 1 & $09 / 08 / 1960$ & Box 48 \\
\hline Revson, Charles (1906 - 1975) & $\begin{array}{l}\text { American Businessman and } \\
\text { Philanthropist }\end{array}$ & 1 & $18 / 02 / 1969$ & Box 48 \\
\hline Ribicoff, Abraham (1910 - 1998) & American Politician & 3 & $22 / 02 / 1962$ & $\begin{array}{l}\text { Box } 48 \\
\text { Box } 74\end{array}$ \\
\hline Rice, Tim (1944) & British Lyricist & 3 & $13 / 06 / 1978$ & Box 63 \\
\hline Richards, Eugene (1944) & American Photographer & 2 & $15 / 09 / 1977$ & Box 48 \\
\hline Richardson, Elliot (1920 - 1999) & American Lawyer & 2 & $09 / 04 / 1974$ & Box 48 \\
\hline Richardson, Sir Ralph (1902 - 1983) & English Actor & 6 & $13 / 06 / 1978$ & $\begin{array}{l}\text { Box } 21 \\
\text { Oversized }\end{array}$ \\
\hline
\end{tabular}




\begin{tabular}{|c|c|c|c|c|}
\hline Richier, Germaine (1904 - 1959) & French Sculptor and Draftsman & 3 & $12 / 10 / 1956$ & Box 48 \\
\hline Rickey, Branch (1881 - 1965) & American Executive & 2 & $01 / 10 / 1959$ & Box 48 \\
\hline Rickey, George (1907 - 2002) & American Sculptor & 8 & 28/12/1973 & Box 48 \\
\hline Rickover, Hyman George (1900 - 1986) & American Admiral & 1 & $21 / 02 / 1962$ & Box 1 \\
\hline Riley, Bridget (1931) & English Painter and Printmaker & 4 & $22 / 06 / 1966$ & Box 49 \\
\hline Riopelle, Jean-Paul (1923 - 2002) & Canadian Painter and Sculptor & 4 & $21 / 07 / 1954$ & Box 49 \\
\hline Rivers, Larry (1923 - 2002) & American Painter and Sculptor & 3 & $03 / 08 / 1975$ & Box 49 \\
\hline Robards, Jason (1922 - 2000) & American Actor & 5 & $05 / 01 / 1974$ & Box 49 \\
\hline Robbins, Jerome (1918 - 1998) & $\begin{array}{l}\text { American Theater Producer and } \\
\text { Director }\end{array}$ & $\begin{array}{l}3 \\
3 \\
1 \\
1\end{array}$ & $\begin{array}{l}08 / 01 / 1958 \\
02 / 04 / 1958 \\
01 / 10 / 1958 \\
07 / 10 / 1958\end{array}$ & Box 49 \\
\hline Robbins, Warren (1923 - 2008) & American Art Collector & 1 & $19 / 09 / 1987$ & Box 49 \\
\hline Robertson, Howard (1903 - 1961) & American Physicist & 1 & $18 / 06 / 1948$ & Box 49 \\
\hline Robinson, Sugar Ray (1921 - 1989) & American Boxer & 4 & $12 / 03 / 1960$ & Box 49 \\
\hline Rockefeller, Blanchette (1909 - 1992) & American Philanthropist & 1 & $11 / 07 / 1979$ & Box 49 \\
\hline Rockefeller, David (1915) & American Banker & $\begin{array}{l}1 \\
1\end{array}$ & $\begin{array}{l}21 / 11 / 1962 \\
03 / 04 / 1981\end{array}$ & Box 49 \\
\hline Rockefeller, John D. III (1906 - 1978) & American Banker & $\begin{array}{l}6 \\
2\end{array}$ & $\begin{array}{l}14 / 11 / 1962 \\
11 / 06 / 1964\end{array}$ & Box 49 \\
\hline Rockefeller, Laurance (1910 - 2004) & American Financer & $\begin{array}{l}1 \\
4\end{array}$ & $\begin{array}{l}30 / 11 / 1962 \\
16 / 09 / 1963\end{array}$ & Box 49 \\
\hline Rockefeller, Nelson (1908 - 1979) & American Businessman & 3 & $06 / 02 / 1948$ & Box 49 \\
\hline Rockefeller, Winthrop (1912 - 1973) & $\begin{array}{l}\text { American Politician and } \\
\text { Philanthropist }\end{array}$ & 1 & $14 / 11 / 1962$ & Box 49 \\
\hline Rogers, Ginger (1911 -1995) & American Actress, Dancer & 1 & $18 / 10 / 1951$ & Box 49 \\
\hline Rogoff, Mortimer (1921 - 2008) & American Inventor & 1 & $23 / 01 / 1974$ & Box 49 \\
\hline Rome, Harold (1908 - 1993) & $\begin{array}{l}\text { American Composer, Lyricist and } \\
\text { Writer }\end{array}$ & $\begin{array}{l}1 \\
1 \\
2 \\
2 \\
1 \\
1\end{array}$ & $\begin{array}{l}22 / 02 / 1961 \\
03 / 01 / 1962 \\
28 / 01 / 1962 \\
29 / 03 / 1964 \\
22 / 09 / 1970 \\
24 / 01 / 1986\end{array}$ & $\begin{array}{l}\text { Box } 49 \\
\text { Box } 74\end{array}$ \\
\hline Romney, George (1907 - 1995) & $\begin{array}{l}\text { American Businessman and } \\
\text { Politician }\end{array}$ & $\begin{array}{l}1 \\
2\end{array}$ & $\begin{array}{l}22 / 06 / 1960 \\
31 / 03 / 1962\end{array}$ & Box 50 \\
\hline Ronis, Willy (1910 - 2009) & French Photographer & 3 & $04 / 08 / 1980$ & Box 50 \\
\hline Roosevelt, Eleanor (1884 - 1962) & American First Lady & 3 & $25 / 01 / 1962$ & Box 50 \\
\hline Roosevelt, Franklin Delano Jr. & American Politician & 2 & $06 / 09 / 1954$ & Box 50 \\
\hline Rorimer, James (1905 - 1966) & American Curator & 3 & $08 / 01 / 1956$ & Box 50 \\
\hline Rosen, Ken (Unknown) & American Author and Mathematician & 1 & 19/03/1977 & Box 50 \\
\hline Rosenquist, James (1933) & American Artist & 3 & 09/01/1980 & Box 50 \\
\hline Rosenthal, Tony (1914 - 2009) & American Sculptor & 4 & $18 / 05 / 1974$ & Box 50 \\
\hline Ross, Steve (1927 - 1992) & American Businessman & 1 & 06/01/1981 & Box 50 \\
\hline Rothman, David (Unknown) & American Author & 3 & $03 / 06 / 1999$ & Box 50 \\
\hline $\begin{array}{l}\text { Rothschild, Edmond James de (1845 - } \\
\text { 1934) }\end{array}$ & French Banker & 1 & $13 / 04 / 1961$ & Box 50 \\
\hline Rothschild, Élie (1917 - 2007) & French Banker & 3 & 20/04/1961 & Box 50 \\
\hline Rothschild, Guy de (1909 - 2007) & French Banker & 2 & $22 / 04 / 1961$ & Box 50 \\
\hline Rothschild, Jacob (1936) & British Investment Banker & 2 & $31 / 03 / 1961$ & Box 35 \\
\hline
\end{tabular}




\begin{tabular}{|c|c|c|c|c|}
\hline $\begin{array}{l}\text { Rothschild, Nathaniel Charles Jacob } \\
\text { (1936) }\end{array}$ & British Banker & 2 & $31 / 03 / 1961$ & Box 35 \\
\hline Rouault, George (1871 - 1958) & French Painter and Printmaker & 11 & $13 / 04 / 1957$ & $\begin{array}{l}\text { Box } 50 \\
\text { Box } 74\end{array}$ \\
\hline Rovem, Ned (1923) & American Composer and Diarist & 3 & $02 / 05 / 1987$ & $\begin{array}{l}\text { Box } 51 \\
\text { Box } 74\end{array}$ \\
\hline Rubenstein, Arturo (1887 - 1982) & Polish/American Pianist & $\begin{array}{l}3 \\
1\end{array}$ & $\begin{array}{l}24 / 02 / 1956 \\
22 / 03 / 1962\end{array}$ & Box 51 \\
\hline Rubin, Reuven (1893 - 1974) & Romanian-Israeli Artist & 2 & $12 / 11 / 1962$ & Box 48 \\
\hline Rubinstein, Helena (1870 - 1965) & American Businesswoman & 3 & $01 / 12 / 1948$ & Box 51 \\
\hline Rudolph, Paul (1918 - 1997) & American Architect & $\begin{array}{l}1 \\
3\end{array}$ & $\begin{array}{l}08 / 10 / 1964 \\
22 / 03 / 1976\end{array}$ & Box 51 \\
\hline Ruscha, Edward (1937) & $\begin{array}{l}\text { American Painter, Photographer and } \\
\text { Printmaker }\end{array}$ & 5 & $11 / 11 / 1985$ & $\begin{array}{l}\text { Box } 51 \\
\text { Oversized }\end{array}$ \\
\hline Rusk, Dean (1909 - 1994) & American Secretary of State & 3 & $02 / 06 / 1962$ & Box 51 \\
\hline Sagan, Françoise (1935 - 2004) & French Playwright and Screenwriter & 2 & $28 / 10 / 1968$ & Box 51 \\
\hline Sainte-Marie, Buffy (1941) & Canadian/American Cree Artist & 3 & $30 / 12 / 1966$ & Box 56 \\
\hline Salinger, Pierre (1925 - 2004) & $\begin{array}{l}\text { American White House Press } \\
\text { Secretary }\end{array}$ & $\begin{array}{l}1 \\
1 \\
2\end{array}$ & $\begin{array}{l}03 / 01 / 1948 \\
11 / 12 / 1961 \\
11 / 02 / 1963\end{array}$ & $\begin{array}{l}\text { Box } 51 \\
\text { Box } 74\end{array}$ \\
\hline Salk, Jonas (1914 - 1995) & American Scientist & $\begin{array}{l}2 \\
4\end{array}$ & $\begin{array}{l}25 / 02 / 1975 \\
05 / 04 / 1991\end{array}$ & $\begin{array}{l}\text { Box } 51 \\
\text { Box } 74\end{array}$ \\
\hline Samras, Lucas (1936) & $\begin{array}{l}\text { American Photographer, Painter and } \\
\text { Installation Artist }\end{array}$ & 7 & $23 / 05 / 1980$ & Box 51 \\
\hline Sandberg, Willem (1897 - 1984) & Dutch Typographer and Curator & 1 & $20 / 04 / 1978$ & Box 51 \\
\hline Sandburg, Carl (1878 - 1967) & American Poet & $\begin{array}{l}6 \\
2\end{array}$ & $\begin{array}{l}03 / 11 / 1955 \\
15 / 05 / 1959\end{array}$ & Box 51 \\
\hline Sanders, Felica (1922 - 1975) & American Pop Artist & 3 & $31 / 01 / 1955$ & Box 52 \\
\hline Scanga, Italo (1932 - 2001) & Italian-American Artist & 1 & $08 / 11 / 1985$ & Oversized \\
\hline Schaffer, Paul (1963) & Canadian-American Musician & 1 & $22 / 09 / 1975$ & Box 52 \\
\hline Schapiro, Meyer (1904- 1996) & American Art Historian & 1 & $01 / 06 / 1979$ & Box 54 \\
\hline Schick, Bella (1877 - 1967) & American Medical Doctor & 2 & $6 / 15 / 1947$ & Box 52 \\
\hline $\begin{array}{l}\text { Schlesinger, Arthur Meier Jr. (1917 - } \\
\text { 2007) }\end{array}$ & American Historian & 2 & $07 / 07 / 1965$ & Box 52 \\
\hline Schwartz, Harry (1924 - 2010) & South African Lawyer & $\begin{array}{l}1 \\
3\end{array}$ & $\begin{array}{l}19 / 02 / 1953 \\
13 / 03 / 1953\end{array}$ & Box 52 \\
\hline Schwartz, Manfred (1909 - 1970) & Polish-American Artist & 2 & $05 / 01 / 1956$ & Box 52 \\
\hline Scorsese, Martin (1942) & American Film Director & 1 & $05 / 10 / 1999$ & Box 37 \\
\hline Scotese, Peter (Unknown) & American Businessman & 2 & $11 / 09 / 1979$ & Box 52 \\
\hline Scott, Willard (1934) & $\begin{array}{l}\text { American Actor, Author and Media } \\
\text { Personality }\end{array}$ & 4 & $13 / 10 / 1982$ & Box 52 \\
\hline Seaborg, Glenn (1912 - 1999) & American Scientist & 2 & $14 / 06 / 1948$ & Box 52 \\
\hline Seberg, Jean (1938 - 1979) & American Actress & 2 & $20 / 04 / 1961$ & Box 52 \\
\hline
\end{tabular}




\begin{tabular}{|c|c|c|c|c|}
\hline Segal, George (1924 - 2000) & American Sculptor & $\begin{array}{l}3 \\
4 \\
3 \\
5 \\
2 \\
4 \\
14 \\
2 \\
1 \\
2 \\
1 \\
13 \\
1\end{array}$ & $\begin{array}{l}01 / 04 / 1964 \\
04 / 09 / 1966 \\
29 / 03 / 1970 \\
04 / 11 / 1976 \\
06 / 10 / 1979 \\
29 / 03 / 1980 \\
18 / 02 / 1982 \\
26 / 06 / 1982 \\
15 / 08 / 1982 \\
21 / 11 / 1983 \\
09 / 06 / 1985 \\
06 / 08 / 1985 \\
10 / 08 / 1999\end{array}$ & $\begin{array}{l}\text { Box } 3 \\
\text { Box } 53 \\
\text { Box } 74\end{array}$ \\
\hline Selassie, Haile I (1892 - 1975) & Ethiopian Regent & 2 & $22 / 11 / 1958$ & Box 17 \\
\hline Seldado, Sebastiao (1944) & Brazilian Photographer & 4 & 19/08/1991 & Box 51 \\
\hline Seldes, Gilbert (1893 - 1970) & American Writer and Critic & 2 & $15 / 01 / 1957$ & Box 54 \\
\hline Seliger, Charles (1926 - 2009) & American Painter and Designer & 2 & $13 / 06 / 2002$ & Box 10 \\
\hline Selye, Hans (1907 - 1982) & Hungarian Endocrinologist & 2 & $01 / 07 / 1958$ & Box 54 \\
\hline Shahn, Ben (1898 - 1969) & $\begin{array}{l}\text { American Painter, Photographer and } \\
\text { Lithographer }\end{array}$ & $\begin{array}{l}2 \\
1 \\
4 \\
1\end{array}$ & $\begin{array}{l}6 / 15 / 1946 \\
12 / 01 / 1951 \\
14 / 01 / 1951 \\
31 / 03 / 1958\end{array}$ & Box 54 \\
\hline Shapiro, Irving (1916 - 2001) & American Lawyer and Businessman & 1 & $30 / 11 / 1973$ & Box 54 \\
\hline Sharon, Ariel (1928) & Israeli General & $\begin{array}{l}2 \\
2\end{array}$ & $\begin{array}{l}12 / 05 / 1979 \\
23 / 04 / 1979\end{array}$ & Box 54 \\
\hline Shaver, Dorothy (1893 - 1959) & American Businesswoman & 1 & $04 / 04 / 1947$ & Box 54 \\
\hline Sheeler, Charles (1883 - 1965) & American Painter and Photographer & 3 & $10 / 1 / 1942$ & Box 54 \\
\hline Shemi, Yehiel (1922) & Israeli Sculptor & 5 & $24 / 05 / 1982$ & $\begin{array}{l}\text { Box } 54 \\
\text { Box } 74\end{array}$ \\
\hline Shenk, Richard L. (1940 - 2011) & American Photographer & 2 & $14 / 03 / 1983$ & Box 54 \\
\hline Shenk, Sol (1911 - 1994) & American Businessman & 1 & $11 / 09 / 1986$ & Box 54 \\
\hline Shenka, Florence (Unknown) & Relation to Sol Shenk & 1 & $11 / 09 / 1986$ & Box 54 \\
\hline Sherman, George (1908 - 1991) & American Film Director, Producer & 1 & $01 / 11 / 1949$ & Box 54 \\
\hline Shriner, Herb (1918 - 1970) & American Humorist & 1 & $16 / 09 / 1955$ & Box 54 \\
\hline Shuman, Fred (Unknown) & $\begin{array}{l}\text { British Businessman and Art } \\
\text { Collector }\end{array}$ & 1 & $20 / 05 / 2004$ & Box 54 \\
\hline Shuman, Stephanie (Unknown) & Spouse to Fred Shuman & 1 & $20 / 05 / 2004$ & Box 54 \\
\hline Sibley, Don (Unknown) & Relation to Marilyn Sibley & 1 & $14 / 02 / 2000$ & Box 15 \\
\hline Sibley, Marilyn (1921 - 2006) & American Historian & 1 & $14 / 02 / 2000$ & Box 15 \\
\hline Sill, Lester (1918 - 1994) & American Businessman & 1 & $13 / 08 / 1975$ & Box 54 \\
\hline Simenon, Georges (1903 - 1989) & Belgian Writer & 1 & $24 / 10 / 1968$ & Box 55 \\
\hline Simon, Neil (1927) & $\begin{array}{l}\text { American Playwright and } \\
\text { Screenwriter }\end{array}$ & 1 & $22 / 09 / 1999$ & Box 42 \\
\hline Simone, Beck (1904 - 1991) & French Chef, Author and Teacher & 1 & $29 / 06 / 1970$ & Box 11 \\
\hline Singer, Isaac Bashevis (1902 - 1991) & Jewish-American Author & 5 & $29 / 02 / 1968$ & Box 55 \\
\hline Siporin, Mitch (1910 - 1976) & American Painter & 1 & $6 / 16 / 1946$ & Box 55 \\
\hline Siskind, Aaron (1903 - 1991) & American Photographer & 3 & $23 / 05 / 1976$ & $\begin{array}{l}\text { Box } 55 \\
\text { Box } 74\end{array}$ \\
\hline
\end{tabular}




\begin{tabular}{|c|c|c|c|c|}
\hline Sloan, John French (1871 - 1951) & American Artist & $\begin{array}{l}1 \\
2 \\
1\end{array}$ & $\begin{array}{l}01 / 10 / 1941 \\
06 / 10 / 1941 \\
03 / 09 / 1941\end{array}$ & Box 55 \\
\hline Smith, Chesterfield Harvey (1917 - 2003) & American Lawyer & 1 & $11 / 06 / 1997$ & Box 55 \\
\hline Smith, Howard W. (1883 - 1976) & American Politician & 1 & $01 / 02 / 1960$ & Box 55 \\
\hline Smith, Margaret Chase (1897 - 1995) & American Politician & 2 & $10 / 07 / 1953$ & Box 55 \\
\hline Smith, Tony $(1912$ - 1980) & American Sculptor and Artist & 5 & $25 / 10 / 1967$ & Box 55 \\
\hline Smith, William Eugene (1918 - 1978) & American Photographer & 9 & $01 / 03 / 1977$ & Box 55 \\
\hline Smith, Willie "The Lion" (1893 - 1973) & American Pianist & 5 & $09 / 03 / 1960$ & Box 55 \\
\hline Snow, Charles Percy (1905 - 1980) & English Chemist & 3 & $23 / 06 / 1966$ & Box 56 \\
\hline Solms, Mrs. Steve (1929 - 2010) & American Philanthropist & 1 & $27 / 10 / 1983$ & Box 56 \\
\hline Solomon, Laura (1974) & New Zealander Author & 1 & $21 / 04 / 2003$ & Box 56 \\
\hline Solomon, Mitzi (1918 - 2006) & American Sculptor & 2 & $06 / 05 / 1945$ & Box 56 \\
\hline $\begin{array}{l}\text { Sonnabend, Abraham Malcolm (1896 - } \\
\text { 1964) }\end{array}$ & American Financier and Businessman & 2 & $03 / 03 / 1961$ & Box 56 \\
\hline Soulages, Pierre (1919) & French Painter and Printmaker & 4 & $21 / 07 / 1954$ & $\begin{array}{l}\text { Box } 56 \\
\text { Box } 78\end{array}$ \\
\hline Soyer, David (1923 - 2010) & American Cellist & 1 & $12 / 01 / 1957$ & Box 56 \\
\hline Soyer, Moses (1899 - 1974) & American Painter & $\begin{array}{l}1 \\
1 \\
2\end{array}$ & $\begin{array}{l}15 / 04 / 1944 \\
20 / 03 / 1965 \\
13 / 11 / 1969\end{array}$ & Box 56 \\
\hline Soyer, Raphael (1899 - 1987) & Russian-American Painter & $\begin{array}{l}1 \\
4 \\
1 \\
1 \\
1 \\
4 \\
4\end{array}$ & $\begin{array}{l}07 / 09 / 1942 \\
08 / 09 / 1942 \\
16 / 04 / 1944 \\
11 / 09 / 1945 \\
12 / 01 / 1947 \\
16 / 06 / 1947 \\
16 / 10 / 1979\end{array}$ & $\begin{array}{l}\text { Box } 56 \\
\text { Box } 78 \\
\text { Box } 86\end{array}$ \\
\hline Spivakovsky, Tossy (1906 - 1998) & German Violinist & 1 & $10 / 09 / 1948$ & Box 56 \\
\hline Spock, Benjamin McLane (1903 - 1998) & American Doctor and Author & $\begin{array}{l}3 \\
2\end{array}$ & $\begin{array}{l}23 / 08 / 1991 \\
22 / 08 / 1992\end{array}$ & $\begin{array}{l}\text { Box } 56 \\
\text { Box } 74\end{array}$ \\
\hline Sprague, Peter (1955) & American Guitarist & 3 & $11 / 08 / 1978$ & Box 56 \\
\hline Spruance, Benton (1904 - 1967) & $\begin{array}{l}\text { American Painter, Printmaker and } \\
\text { Architect }\end{array}$ & 2 & 06/07/1945 & Box 56 \\
\hline Stanford, Henry King (1916 - 2009) & American Professor & 1 & $04 / 05 / 1964$ & Box 57 \\
\hline Stanley, Kim (1925 - 2001) & American Actress & $\begin{array}{l}5 \\
5\end{array}$ & $\begin{array}{l}07 / 05 / 1963 \\
20 / 05 / 1963\end{array}$ & $\begin{array}{l}\text { Box } 57 \\
\text { Box } 74\end{array}$ \\
\hline Stassen, Harold (1907 - 2001) & American Politician & 1 & $01 / 06 / 1946$ & Box 57 \\
\hline Steichen, Edward (1879 - 1973) & American Photographer & $\begin{array}{l}4 \\
3\end{array}$ & $\begin{array}{l}09 / 11 / 1951 \\
15 / 11 / 1955\end{array}$ & $\begin{array}{l}\text { Box } 16 \\
\text { Box } 57 \\
\text { Box } 74 \\
\end{array}$ \\
\hline Steig, William (1907 - 2003) & American Cartoonist and Author & $\begin{array}{l}2 \\
2\end{array}$ & $\begin{array}{l}12 / 04 / 1944 \\
06 / 09 / 1946\end{array}$ & Box 57 \\
\hline Steinberg, Saul (1914 - 1999) & American Cartoonist and Illustrator & $\begin{array}{l}3 \\
2\end{array}$ & $\begin{array}{l}21 / 02 / 1947 \\
22 / 01 / 1951\end{array}$ & Box 57 \\
\hline Steinway, Henry (1915 - 2008) & American Businessman & 3 & $01 / 09 / 1977$ & Box 57 \\
\hline Stella, Frank (1936) & $\begin{array}{l}\text { American Painter, Printmaker and } \\
\text { Mixed-Media Artist }\end{array}$ & 7 & $10 / 10 / 1967$ & $\begin{array}{l}\text { Box } 57 \\
\text { Box } 74\end{array}$ \\
\hline Stella, Joseph (1877 - 1946) & American Futurist & 2 & $06 / 09 / 1943$ & Box 57 \\
\hline
\end{tabular}




\begin{tabular}{|c|c|c|c|c|}
\hline Stern, Isaac (1920 - 2001) & Ukrainian Conductor and Violinist & $\begin{array}{l}1 \\
7 \\
1 \\
1\end{array}$ & $\begin{array}{l}09 / 01 / 1962 \\
23 / 09 / 1985 \\
16 / 11 / 1988 \\
12 / 04 / 1990\end{array}$ & Box 58 \\
\hline Sterne, Hedda (1910 - 2011) & Romanian Artist & 2 & $22 / 01 / 1951$ & Box 57 \\
\hline Sterne, Maurice (1877 - 1957) & American Sculptor and Painter & 2 & $01 / 09 / 1952$ & Box 58 \\
\hline Stevens, George (1904 - 1975) & $\begin{array}{l}\text { American Film Director, Producer } \\
\text { and Screenwriter }\end{array}$ & 2 & $20 / 01 / 1962$ & Box 58 \\
\hline Stevens, Joseph Edward Jr. (1928 - 1998) & American Judge & 2 & $01 / 02 / 1950$ & Box 58 \\
\hline Stevens, Risë (1913) & American Singer & 2 & $18 / 05 / 1956$ & Box 58 \\
\hline Stevenson, Adlai (1900 - 165) & American Politician & $\begin{array}{l}2 \\
3\end{array}$ & $\begin{array}{l}01 / 02 / 1952 \\
12 / 03 / 1962\end{array}$ & $\begin{array}{l}\text { Box } 61 \\
\text { Box } 74\end{array}$ \\
\hline Stewart, Jackie (1939) & English Racing Driver & 1 & $03 / 06 / 1978$ & Oversized \\
\hline Stieglitz, Alfred (1864 - 1946) & American Photographer & $\begin{array}{l}2 \\
6\end{array}$ & $\begin{array}{l}05 / 04 / 1944 \\
17 / 04 / 1944\end{array}$ & Box 58 \\
\hline Stockhausen, Karlheinz (1928 - 2007) & German Composer & 1 & $07 / 07 / 1964$ & Box 58 \\
\hline Stoppard, Tom (1937) & Czech-British Playwright & 2 & $08 / 06 / 1978$ & $\begin{array}{l}\text { Box } 46 \\
\text { Oversized }\end{array}$ \\
\hline Strand, Paul (1880 - 1976) & $\begin{array}{l}\text { American Photographer and } \\
\text { Filmmaker }\end{array}$ & 6 & $30 / 01 / 1966$ & Box 58 \\
\hline Stravinsky, Igor (1882 - 1971) & Russian Composer & $\begin{array}{l}5 \\
8 \\
4 \\
3 \\
2\end{array}$ & $\begin{array}{l}01 / 12 / 1946 \\
14 / 01 / 1963 \\
05 / 11 / 1966 \\
13 / 12 / 1966 \\
08 / 01 / 1967\end{array}$ & $\begin{array}{l}\text { Box } 59 \\
\text { Oversized }\end{array}$ \\
\hline Stubbins, Hugh (1912 - 2006) & American Architect & 1 & $13 / 08 / 1979$ & Box 59 \\
\hline Stutz, Geraldine (1924 - 2005) & American Businesswoman & 4 & $05 / 09 / 1969$ & Box 58 \\
\hline Sulzberger, Arthur Ochs Jr. (1951 - 1992) & American Publisher & 4 & $25 / 08 / 1976$ & Box 59 \\
\hline Sulzberger, Arthur Ochs Sr. (1926 - 2012) & American Publisher & $\begin{array}{l}4 \\
1\end{array}$ & $\begin{array}{l}12 / 10 / 1951 \\
04 / 05 / 1956\end{array}$ & Box 59 \\
\hline Surtees, John (1934) & English Racing Driver & 1 & $03 / 06 / 1978$ & Oversized \\
\hline Suvero, Mark di (1933) & American Sculptor & 2 & $23 / 02 / 1980$ & Box 59 \\
\hline Symington, Stuart (1901 - 1988) & $\begin{array}{l}\text { American Businessman and } \\
\text { Politician }\end{array}$ & 2 & $13 / 07 / 1953$ & Box 59 \\
\hline Taft, Robert (1889 - 1953) & American Politician & 1 & $31 / 05 / 1952$ & Box 59 \\
\hline Takis, Vassilakis (1925) & Greek Artist & 2 & $25 / 04 / 1970$ & Box 59 \\
\hline Tamayo, Olga (Unknown) & Spouse to Rufino Tamayo & 1 & 03/01/1949 & Box 59 \\
\hline Tamayo, Rufino (1899 - 1991) & Mexican Painter & $\begin{array}{l}2 \\
4\end{array}$ & $\begin{array}{l}02 / 12 / 1959 \\
18 / 10 / 1965\end{array}$ & $\begin{array}{l}\text { Box } 59 \\
\text { Box } 74\end{array}$ \\
\hline Tanning, Dorothea (1910 - 2012) & American Painter and Printmaker & 1 & $13 / 01 / 1988$ & Box 60 \\
\hline Tapié, Michel (1909 - 1987) & $\begin{array}{l}\text { French Art Critic, Curator and } \\
\text { Collector }\end{array}$ & 3 & $12 / 05 / 1954$ & Box 60 \\
\hline Tàpies, Antoni (1923 - 2012) & Catalan Artist & $\begin{array}{l}3 \\
3 \\
3\end{array}$ & $\begin{array}{l}19 / 03 / 1961 \\
04 / 12 / 1964 \\
21 / 05 / 1990\end{array}$ & $\begin{array}{l}\text { Box } 60 \\
\text { Box } 74\end{array}$ \\
\hline
\end{tabular}




\begin{tabular}{|c|c|c|c|c|}
\hline Tavoulareas, William (1919 - 1996) & American Businessman & $\begin{array}{l}1 \\
1 \\
1\end{array}$ & $\begin{array}{l}12 / 11 / 1973 \\
17 / 01 / 1979 \\
24 / 01 / 1980\end{array}$ & Box 63 \\
\hline Teller, Edward (1908 - 2003) & Hungarian American Scientist & 2 & $21 / 12 / 1961$ & Box 60 \\
\hline Tenneson, Joyce (1945) & Fine Art Photographer & 2 & 14/08/1991 & Box 60 \\
\hline Tharp, Twyla (1941) & American Dancer and Choreographer & 2 & $14 / 05 / 1987$ & Box 60 \\
\hline Theiler, Max (1899 - 1972) & South African Scientist & 4 & $22 / 10 / 1951$ & Box 60 \\
\hline Theodore Kheel (1914 - 2010) & American Attorney & 1 & $09 / 11 / 1961$ & Box 60 \\
\hline Thielicke, Helmut (1908 - 1986) & German Professor & 1 & $02 / 07 / 1964$ & Box 60 \\
\hline Thomas, Michael Tilson (1944) & $\begin{array}{l}\text { American Conductor, Pianist and } \\
\text { Composer }\end{array}$ & $\begin{array}{l}2 \\
2 \\
2\end{array}$ & $\begin{array}{l}10 / 05 / 1973 \\
12 / 08 / 1976 \\
\text { Unknown }\end{array}$ & Box 60 \\
\hline Thompson, John F. (1920 - 1965) & American Politician & 1 & 23/03/1966 & Box 60 \\
\hline Thomson, Virgil (1896 - 1989) & American Composer and Critic & 2 & 03/09/1976 & Box 60 \\
\hline Thorne, Oakliegh (1866 - 1948) & American Businessman & 1 & 13/06/1973 & Box 60 \\
\hline Tilson, Joe (1928) & British Artist & 2 & $24 / 06 / 1966$ & Box 60 \\
\hline Tippett, Sir Michael (1905 - 1998) & English Composer & 1 & $16 / 05 / 1978$ & Box 60 \\
\hline Todd, Alexander R. (1907 - 1997) & Scottish Biochemist & 1 & $19 / 05 / 1978$ & Oversized \\
\hline Tourell, Jennie $(1900$ - 1973) & Russian-American Singer & 3 & $12 / 09 / 1948$ & Box 61 \\
\hline Toynbee, Arnold J. (1889 - 1975) & British Historian & 4 & $10 / 03 / 1969$ & Box 61 \\
\hline Trova, Ernest (1927 - 2009) & American Artist & 7 & 09/01/1971 & Box 61 \\
\hline Truman Capote (1924 - 1984) & American Author & 3 & 28/06/1977 & Box 9 \\
\hline Truman, Harry S. (1884 - 1972) & American President & 3 & 19/06/1960 & Box 61 \\
\hline Truman, Margaret (1924 - 2008) & American Singer & $\begin{array}{l}2 \\
1\end{array}$ & $\begin{array}{l}19 / 02 / 1951 \\
01 / 01 / 1952\end{array}$ & Box 61 \\
\hline Tubman, William V. (1895 - 1971) & Liberian Politician & 2 & $15 / 10 / 1958$ & Box 61 \\
\hline Tully, Alice (1902-1993) & American Singer & 2 & 08/09/1976 & Box 61 \\
\hline Tumarkin, Yigal (1933) & Israeli Painter and Sculptor & $\begin{array}{l}3 \\
4\end{array}$ & $\begin{array}{l}10 / 05 / 1965 \\
20 / 08 / 1967\end{array}$ & Box 61 \\
\hline Turner, Catledge (1901 - 1983) & American Journalist & 1 & $16 / 06 / 1952$ & Box 61 \\
\hline Turner, Pete (1934) & American Photographer & 1 & $14 / 02 / 1997$ & Box 61 \\
\hline Turrell, James (1943) & American Artist & 1 & $13 / 11 / 1985$ & Box 61 \\
\hline Twining, Nathan Farragut (1897 - 1982) & American Air Force Officer & 1 & $01 / 02 / 1960$ & Box 61 \\
\hline Tworkov, Jack (1900 -1982) & American Painter & $\begin{array}{l}3 \\
4\end{array}$ & $\begin{array}{l}18 / 08 / 1960 \\
15 / 07 / 1973\end{array}$ & Box 61 \\
\hline Udall, Stewart (1920 - 2010) & American Politician & 1 & $07 / 01 / 1965$ & Box 61 \\
\hline Uelsmann, Jerry (1934) & American Photographer & 6 & $11 / 11 / 1980$ & Box 61 \\
\hline Van Dyke, Marcia (1924 - 2002) & American Actress & 2 & $21 / 05 / 1951$ & Box 62 \\
\hline Van Fleet, James (1892 - 1992) & American Military Officer & 1 & $29 / 04 / 1953$ & Box 62 \\
\hline Vanderbilt, Amy (1908 - 1974) & American Author & 1 & $01 / 07 / 1959$ & Box 62 \\
\hline Vevers, Tony (1926 - 2008) & American Artist & 1 & $11 / 07 / 1993$ & Box 62 \\
\hline Vicente, Estaben (1903 - 2001) & American Painter & 2 & $22 / 04 / 1996$ & Box 62 \\
\hline Vidal, Gore (1925 - 2012) & American Writer & $\begin{array}{l}5 \\
1 \\
\end{array}$ & $\begin{array}{l}01 / 10 / 1946 \\
05 / 02 / 1982\end{array}$ & Box 62 \\
\hline Villa-Lobos, Heitor (1887 - 1959) & Brazilian Composer & 7 & $15 / 09 / 1951$ & $\begin{array}{l}\text { Box } 62 \\
\text { Box } 74 \\
\text { Box } 79\end{array}$ \\
\hline Villon, Jacques (1875 - 1963) & French Painter & 9 & $13 / 04 / 1957$ & Box 62 \\
\hline
\end{tabular}




\begin{tabular}{|c|c|c|c|c|}
\hline & & & & Box 74 \\
\hline Von Wiegand, Charmion (1896 - 1983) & American Journalist and Artist & 2 & $16 / 08 / 1961$ & Box 62 \\
\hline Vorse, Mary Heaton (1874-1966) & American Journalist & 1 & $18 / 08 / 1964$ & Box 62 \\
\hline Vreeland, Diana (1903 - 1989) & American Magazine Editor & 3 & $25 / 08 / 1974$ & Box 62 \\
\hline Wagner, Robert F. (1877 - 1953) & American Politician & 1 & $06 / 09 / 1954$ & Box 62 \\
\hline Wagstaff, Sam (1921 - 1987) & American Art Curator and Collector & 1 & $02 / 04 / 1976$ & Box 62 \\
\hline Wallace, DeWitt (1889 - 1981) & American Magazine Publisher & 1 & $19 / 10 / 1951$ & Box 63 \\
\hline Wallace, Henry (1888 - 1965) & American Politician & 3 & $18 / 04 / 1956$ & Box 63 \\
\hline Wallace, Lila Bell (1889 - 1984) & American Publisher & 4 & $19 / 10 / 1951$ & Box 63 \\
\hline Wallach, Eli (1915) & American Actor & $\begin{array}{l}2 \\
2\end{array}$ & $\begin{array}{l}14 / 06 / 1961 \\
09 / 08 / 1984\end{array}$ & Box 63 \\
\hline Walton, Sir Williams (1902 - 1983) & English Composer & 1 & $25 / 05 / 1978$ & Oversized \\
\hline Warhol, Andy (1928 - 1987) & American Artist & 3 & $02 / 02 / 1973$ & Box 63 \\
\hline Warren, Earl (1891 - 1974) & American Justice and Politician & $\begin{array}{l}4 \\
4 \\
1\end{array}$ & $\begin{array}{l}01 / 02 / 1960 \\
27 / 11 / 1961 \\
22 / 04 / 1964\end{array}$ & $\begin{array}{l}\text { Box } 63 \\
\text { Box } 74\end{array}$ \\
\hline Wassom, Gordon (1898 - 1986) & American Author & 3 & $23 / 02 / 1957$ & Box 63 \\
\hline Watkins, Franklin (1894 - 1972) & American Painter & 2 & $16 / 09 / 1943$ & Box 63 \\
\hline Watkins, Tom (1937 - 2011) & American Football Player & 1 & $06 / 07 / 1974$ & Box 63 \\
\hline Watson, James (1928) & American Scientist & 1 & $12 / 09 / 1964$ & Box 63 \\
\hline Watson, John B. (1878 - 1958) & American Psychologist & 1 & $07 / 06 / 1990$ & Box 63 \\
\hline Watts, Andre (1946) & American/German Pianist & 3 & $06 / 12 / 1983$ & Box 63 \\
\hline Wauneka, Annie Dodge (1910 - 1997) & Navajo First Nation Councillor & 3 & $19 / 09 / 1955$ & Box 63 \\
\hline Webber, Andrew Lloyd (1948) & English Composer & 3 & $13 / 06 / 1978$ & Box 63 \\
\hline Weber, Max (1881 - 1961) & American Artist & $\begin{array}{l}2 \\
4\end{array}$ & $\begin{array}{l}09 / 11 / 1942 \\
15 / 09 / 1943\end{array}$ & Box 63 \\
\hline Weicker, Lowell P. Jr. (1931) & American Politician & 3 & $01 / 05 / 1974$ & Box 64 \\
\hline Weill, Sanford (1933) & American Banker & 1 & $12 / 04 / 1990$ & Box 66 \\
\hline Weinstein, Henry (1924 - 2000) & American Film Producer & $\begin{array}{l}1 \\
14\end{array}$ & $\begin{array}{l}04 / 10 / 1960 \\
20 / 01 / 1962\end{array}$ & $\begin{array}{l}\text { Box } 40 \\
\text { Box } 64\end{array}$ \\
\hline Weisman, Frederick (1930) & $\begin{array}{l}\text { American Filmmaker and } \\
\text { Documentarist }\end{array}$ & 1 & $03 / 11 / 1985$ & Box 64 \\
\hline Weitzen,Hyman (Unknown) & American Museum Director & 1 & $08 / 03 / 1970$ & Box 64 \\
\hline Weitzenhoffer, Frances (1945 - 1991) & American Art Historian & 1 & $16 / 09 / 1986$ & Box 64 \\
\hline Welch, Joseph N. (1890 - 1960) & American Politician & 2 & $21 / 02 / 1957$ & Box 64 \\
\hline Welliver, Neil (1929 - 2005) & American Artist & 1 & $03 / 08 / 1990$ & Box 64 \\
\hline Welpott, Jack (1923) & American Photographer & 2 & $31 / 03 / 1974$ & Box 13 \\
\hline Werden, Lincoln (1904 - 1980) & American Journalist & 2 & $29 / 06 / 1957$ & Box 64 \\
\hline Wesselmann, Tom (1931 - 2004) & American Artist & 6 & $18 / 04 / 1970$ & Box 64 \\
\hline Weston, Cole (1919 - 2003) & American Photographer & 2 & $14 / 06 / 1980$ & Box 65 \\
\hline Weyhe, Erhard (1883 - 1972) & American Gallerist & 4 & 01/01/1952 & $\begin{array}{l}\text { Box } 65 \\
\text { Box } 80 \\
\end{array}$ \\
\hline Whitehead, Edwin C. (1920 - 1992) & American Philanthropist & 2 & $11 / 09 / 1984$ & Box 65 \\
\hline Widmark, Richard (1914 - 2008) & American Actor & 3 & $01 / 06 / 1949$ & Box 65 \\
\hline Wiesel, Elie (1928) & Transylvanian Writer and Professor & 3 & $25 / 11 / 1980$ & $\begin{array}{l}\text { Box } 65 \\
\text { Oversized }\end{array}$ \\
\hline Wiesenthal, Simon (1908 - 2005) & Austrian Nazi-Hunter & 3 & $08 / 05 / 1975$ & Box 64 \\
\hline Wiesner, Jerome (1915 - 1994) & American Scientist & 1 & $02 / 08 / 1965$ & Box 65 \\
\hline
\end{tabular}




\begin{tabular}{|c|c|c|c|c|}
\hline Wilder, Billy (1906 - 2002) & $\begin{array}{l}\text { Austrian/American Filmmaker, } \\
\text { Producer and Journalist }\end{array}$ & 3 & $20 / 01 / 1962$ & Box 65 \\
\hline Wilder, Thorton (1897 - 1975) & American Playwright and Novelist & 6 & 28/01/1962 & Box 65 \\
\hline Wilke, Hannah (1940) & $\begin{array}{l}\text { American Painter, Sculptor and } \\
\text { Photographer }\end{array}$ & 4 & $29 / 07 / 1974$ & Box 65 \\
\hline Wilson, Sir Harold (1916 - 1995) & British Politician & 1 & $13 / 05 / 1978$ & Oversized \\
\hline Wilson, Sol (1896 - 1974) & American Painter & $\begin{array}{l}3 \\
1\end{array}$ & $\begin{array}{l}01 / 07 / 1950 \\
20 / 08 / 1960\end{array}$ & Box 65 \\
\hline Wingate, Henry S. (1905 - 1982) & American Businessman & 1 & $28 / 07 / 1965$ & Box 65 \\
\hline Witkin, Joel Peter (1939) & American Photographer & 2 & $16 / 08 / 1988$ & Box 65 \\
\hline Wolfensohn, James (1933) & American Banker & 1 & $12 / 04 / 1990$ & Box 66 \\
\hline Wolfson, Norman L. (1922 - 2007) & $\begin{array}{l}\text { American Journalist, Politician and } \\
\text { Author }\end{array}$ & 1 & $09 / 01 / 1970$ & Box 66 \\
\hline Wormley, Edward (1907 - 1995) & American Designer & 3 & $06 / 09 / 1948$ & Box 20 \\
\hline Wright, Frank Lloyd (1867 - 1959) & American Architect & 4 & $13 / 10 / 1947$ & Box 66 \\
\hline Wyeth, Andrew (1917 - 2009) & American Painter & $\begin{array}{l}4 \\
5 \\
6 \\
1\end{array}$ & $\begin{array}{l}04 / 16 / 1948 \\
02 / 12 / 1976 \\
24 / 08 / 1994 \\
13 / 08 / 1995\end{array}$ & $\begin{array}{l}\text { Box } 66 \\
\text { Box } 74\end{array}$ \\
\hline Yadin, Yigael (1917 - 1984) & Israeli Archeologist and Politician & $\begin{array}{l}1 \\
1\end{array}$ & $\begin{array}{l}01 / 08 / 1959 \\
24 / 11 / 1967\end{array}$ & $\begin{array}{l}\text { Box } 66 \\
\text { Box } 74\end{array}$ \\
\hline Yamasaki, Minoru (1912 - 1986) & American Architect & 2 & $24 / 06 / 1960$ & Box 66 \\
\hline Yavno, Max (1911 - 1985) & American Photographer & 5 & $08 / 03 / 1985$ & Box 66 \\
\hline Yevtushenko, Yevgeny (1933) & Russian Poet & 3 & $16 / 01 / 1993$ & Box 66 \\
\hline York, Susannah (1939 - 2011) & English Actress & 1 & $12 / 05 / 1978$ & Oversized \\
\hline Young, Milton (1897 - 1983) & American Politician & 1 & $01 / 03 / 1965$ & Box 66 \\
\hline Zadkine, Ossip (1890 - 1967) & French-Russian Artist & 1 & $10 / 10 / 1956$ & Box 66 \\
\hline Zaritsky, Joseph (1891 - 1985) & Israeli Painter & 4 & $05 / 06 / 1982$ & Box 66 \\
\hline Zorach, William (1887 - 1966) & $\begin{array}{l}\text { Lithuanian-American Sculptor, } \\
\text { Painter, Printmaker and Writer }\end{array}$ & 3 & $01 / 09 / 1943$ & Box 66 \\
\hline Zworykin, Vladimir K. (1888 - 1982) & $\begin{array}{l}\text { Russian-American Inventor and } \\
\text { Engineer }\end{array}$ & 1 & $16 / 04 / 1958$ & Box 66 \\
\hline
\end{tabular}

\section{Incomplete Sitting Subject Index}

\begin{tabular}{|l|l|l|l|}
\hline Name & $\#$ & Neg. Date & $\begin{array}{l}\text { General } \\
\text { Location }\end{array}$ \\
\hline Jacobs, Jerrold L. & 2 & $23 / 03 / 1990$ & Box 27 \\
\hline Abrahms, Marc & 2 & $26 / 08 / 1993$ & Box 1 \\
\hline Adams, William R., & 2 & $23 / 09 / 1968$ & Box 1 \\
\hline
\end{tabular}




\begin{tabular}{|c|c|c|c|}
\hline Adler, Ernie & 1 & $21 / 02 / 1967$ & Box 1 \\
\hline Adminstrator Morrison & 1 & $02 / 09 / 1961$ & Box 41 \\
\hline Adnon, Shamuel & 2 & 24/11/1967 & Box 1 \\
\hline Alexander, John White & 1 & $11 / 01 / 1956$ & Box 2 \\
\hline Allen & 1 & $01 / 02 / 1960$ & Box 2 \\
\hline Alston, Elizabeth & 1 & $15 / 03 / 1973$ & Box 2 \\
\hline Ames, John & 1 & $02 / 08 / 1990$ & Box 2 \\
\hline Amore, Carol & 2 & 29/12/1994 & Box 2 \\
\hline Amster, James & 4 & $15 / 02 / 1985$ & Box 2 \\
\hline Arden, Forrest & 2 & $28 / 06 / 1947$ & Box 2 \\
\hline Armstrong, Tom & 1 & $12 / 12 / 1979$ & Box 3 \\
\hline Armstrong, William George & 2 & $15 / 05 / 1978$ & Box 24 \\
\hline Arsht, S. Samuel & 1 & $07 / 11 / 1980$ & Box 3 \\
\hline Ashton, Marie & 3 & $25 / 11 / 1994$ & Box 3 \\
\hline Atamiam, Dickran & 1 & $05 / 11 / 1975$ & Box 3 \\
\hline Austin, C.L. & 1 & $30 / 12 / 1952$ & Box 3 \\
\hline Bagar, Robert & 1 & $14 / 09 / 1977$ & Box 4 \\
\hline Barron, Dr. Moses & 1 & $15 / 08 / 1958$ & Box 4 \\
\hline Barwick, Joann & 1 & $07 / 11 / 1988$ & Box 4 \\
\hline Basch, Sarah & 1 & $16 / 02 / 1988$ & Box 4 \\
\hline Beach, Morrison H. & 2 & $07 / 01 / 1975$ & Box 4 \\
\hline Beasrer, Dr. & 1 & $11 / 07 / 1958$ & Box 4 \\
\hline Beebe, Dr. & 1 & $02 / 07 / 1957$ & Box 4 \\
\hline Begner, Dr. Jack & 2 & $30 / 09 / 1958$ & Box 4 \\
\hline Berentson, John & 1 & $14 / 12 / 1973$ & Box 22 \\
\hline Bergorac, Michel & 1 & $08 / 12 / 1975$ & Box 5 \\
\hline Berkowitz, Roseanna & 1 & $01 / 06 / 2000$ & Box 5 \\
\hline Berlofsky, Lillian & 1 & $13 / 08 / 1990$ & Box 5 \\
\hline Biggs, Stephen & 1 & $11 / 01 / 1956$ & Box 5 \\
\hline Bijur, William & 1 & $29 / 11 / 1956$ & Box 5 \\
\hline Blai, Boris & 1 & $9 / 14 / 1945$ & Box 5 \\
\hline Blair, Felix & 1 & $29 / 09 / 1953$ & Box 5 \\
\hline Blair, William & 1 & $10 / 01 / 1958$ & Box 5 \\
\hline Bohndell, Henry & 1 & $17 / 08 / 1977$ & Box 6 \\
\hline Bongiovanni, Michael & 1 & $23 / 01 / 1976$ & Box 6 \\
\hline Bonhomme, Pierre & 1 & $23 / 04 / 2001$ & Box 6 \\
\hline Booth, Carol & 1 & $15 / 02 / 1996$ & Box 6 \\
\hline Booth, Greg & 1 & $15 / 02 / 1996$ & Box 6 \\
\hline Booth, Warren & 2 & $23 / 06 / 1960$ & Box 6 \\
\hline Botkin, Harry & 1 & $18 / 09 / 1948$ & Box 6 \\
\hline Bracker, Milton & 1 & $26 / 12 / 1956$ & Box 6 \\
\hline
\end{tabular}




\begin{tabular}{|c|c|c|c|}
\hline Brennan, Charles & 1 & $02 / 01 / 1949$ & Box 7 \\
\hline Brett & 1 & $01 / 11 / 1949$ & Box 7 \\
\hline Brown, Robert Dejove & 1 & $21 / 12 / 1971$ & Box 7 \\
\hline Brown, W. Lyons & 1 & $23 / 10 / 1969$ & Box 7 \\
\hline Burch, Peter & 3 & $17 / 12 / 1981$ & Box 8 \\
\hline Burnham, D.C. & 1 & $10 / 10 / 1974$ & Box 8 \\
\hline Burton, T.B. & 1 & $23 / 06 / 1960$ & Box 8 \\
\hline Burton, Will & 2 & $02 / 01 / 1949$ & Box 8 \\
\hline Bush, Dr. Martin & 3 & $13 / 11 / 1969$ & Box 8 \\
\hline Buxbaum, Sandy & 1 & $07 / 02 / 1967$ & Box 8 \\
\hline Cahn, Edmund & 1 & $10 / 10 / 1960$ & Box 9 \\
\hline Calderon, Anna Maria Alvarez & 2 & $01 / 12 / 1949$ & Box 9 \\
\hline Callender, Stuart & 2 & $30 / 04 / 1990$ & Box 9 \\
\hline Campbell, Douglas Argyle & 1 & $07 / 02 / 1973$ & Box 9 \\
\hline Candel, Victor & 3 & 08/08/1964 & Box 9 \\
\hline Carroll, Thomas & 1 & $08 / 12 / 1976$ & Box 10 \\
\hline Cave, Ray & 5 & $23 / 08 / 1984$ & Box 10 \\
\hline Childs, T.W. & 1 & $22 / 12 / 1964$ & Box 11 \\
\hline Clark, Fraser & 1 & $24 / 11 / 1975$ & Box 11 \\
\hline Clarke, E.V. Jr. & 1 & $11 / 10 / 1974$ & Box 11 \\
\hline Clayton, Leonard & 1 & $04 / 07 / 1976$ & Box 11 \\
\hline Cleary, John V. & 1 & $20 / 01 / 1967$ & Box 11 \\
\hline Cogan, Maureen & 1 & $16 / 11 / 1995$ & Box 11 \\
\hline Colin, Ralph & 2 & $08 / 12 / 1972$ & Box 11 \\
\hline Cooper, Paula & 1 & $28 / 09 / 1973$ & Box 12 \\
\hline Costanzo, G.A. & 1 & $21 / 10 / 1976$ & Box 12 \\
\hline Cowels, Russel & 2 & $12 / 09 / 1947$ & Box 13 \\
\hline Cox, E. Morris & 1 & $29 / 03 / 1969$ & Box 13 \\
\hline Crump, Morris Ray & 1 & $24 / 06 / 1963$ & Box 13 \\
\hline Culberg, Morris & 1 & $01 / 08 / 1952$ & Box 81 \\
\hline Dahlberg, Jeffery & 2 & $25 / 11 / 1994$ & Box 13 \\
\hline Dale, Edward & 1 & $08 / 08 / 1957$ & Box 13 \\
\hline Danforth, D.D. & 2 & $28 / 10 / 1974$ & Box 13 \\
\hline Dauphin, Claude & 1 & $03 / 04 / 1968$ & Box 13 \\
\hline Davis, Dr. D. Barry & 1 & $30 / 10 / 1975$ & Box 14 \\
\hline Deall, Clyde & 1 & $11 / 11 / 1951$ & Box 14 \\
\hline DeLigne, Dr. Pierce & 2 & $22 / 02 / 1991$ & Box 14 \\
\hline Dempsey, Dr. James R. & 3 & $08 / 11 / 1962$ & Box 14 \\
\hline DeVeto, Benardo & 3 & $26 / 01 / 1953$ & Box 36 \\
\hline Dixon, Pat & 1 & $19 / 11 / 1984$ & Box 15 \\
\hline Doan, Alexandra & 2 & $14 / 12 / 1992$ & Box 15 \\
\hline
\end{tabular}




\begin{tabular}{|c|c|c|c|}
\hline Duff, James F. & 1 & $11 / 07 / 1953$ & Box 16 \\
\hline Dunkelman, Arnold & 2 & $13 / 03 / 1983$ & Box 16 \\
\hline Dunkelman, Elaine & 2 & $13 / 03 / 1983$ & Box 16 \\
\hline Dupont, E. I. & 2 & $18 / 10 / 1954$ & Box 16 \\
\hline Eaken, Andrew & 1 & $28 / 06 / 1950$ & Box 16 \\
\hline Eble, Charles & 1 & $20 / 01 / 1967$ & Box 16 \\
\hline Ehrlich, Michelle & 2 & $15 / 01 / 1974$ & Box 16 \\
\hline Engel, Harry & 1 & $16 / 08 / 1964$ & Box 17 \\
\hline Epley, Dr. Daniel & 2 & $23 / 10 / 1990$ & Box 17 \\
\hline Ernest, Albert Jr. & 1 & $24 / 09 / 1973$ & Box 17 \\
\hline Ettinger, Mahala & 1 & $11 / 01 / 1956$ & Box 17 \\
\hline Evans, Dr. Earl & 1 & $25 / 08 / 1975$ & Box 17 \\
\hline Evans, M.K. & 2 & 29/10/1974 & Box 17 \\
\hline Faden, Charles A. & 1 & $08 / 10 / 1975$ & Box 18 \\
\hline Feld, Stuart & 4 & $13 / 12 / 1983$ & Box 18 \\
\hline Fellrath, Charles J. & 1 & $22 / 04 / 1967$ & Box 18 \\
\hline Field, Richard & 1 & $11 / 01 / 1956$ & Box 18 \\
\hline Finley, James & 2 & $22 / 03 / 1966$ & Box 18 \\
\hline Finney & 1 & $08 / 08 / 1957$ & Box 18 \\
\hline Fischer, Joe & 1 & $20 / 08 / 1975$ & Box 18 \\
\hline Fleshner, Laura & 3 & $09 / 02 / 1968$ & Box 18 \\
\hline Florsheim, Richard (Dick) & $\begin{array}{l}2 \\
2\end{array}$ & $\begin{array}{l}20 / 08 / 1958 \\
04 / 09 / 1968\end{array}$ & Box 19 \\
\hline Fogelson, Andy & 2 & $11 / 08 / 1975$ & Box 19 \\
\hline Foley, Paul & 2 & $07 / 07 / 1959$ & Box 19 \\
\hline Ford, Colin & $\begin{array}{l}1 \\
1\end{array}$ & $\begin{array}{l}26 / 02 / 1976 \\
05 / 04 / 1989\end{array}$ & Box 19 \\
\hline Forrest, Jack & 1 & $01 / 03 / 1952$ & Box 19 \\
\hline Franco, Bollo & 1 & $02 / 11 / 1982$ & Box 19 \\
\hline Frank, Carr & 1 & $09 / 01 / 1970$ & Box 19 \\
\hline Friedman, Emmuel & 1 & $16 / 01 / 1954$ & Box 20 \\
\hline Garden, Judith & 1 & $04 / 01 / 1985$ & Box 20 \\
\hline Gera, Ella & 1 & $07 / 05 / 1982$ & Box 21 \\
\hline Gera, Oded & 1 & $10 / 09 / 1979$ & Box 60 \\
\hline Gerard, Dr. R.W. & 2 & $20 / 12 / 1958$ & Box 21 \\
\hline Gerrity, Edward & 1 & $04 / 03 / 1981$ & Box 21 \\
\hline Gian, Mario Bycellati & 1 & $15 / 06 / 1971$ & Box 8 \\
\hline Gibbons, Rob & 1 & $24 / 09 / 1947$ & Box 21 \\
\hline Gillmore & 2 & $01 / 11 / 1949$ & Box 21 \\
\hline Ginott, Dr. Chaim & 1 & $13 / 12 / 1971$ & Box 21 \\
\hline Gordon, J. Roy & 2 & $30 / 03 / 1964$ & Box 22 \\
\hline
\end{tabular}




\begin{tabular}{|c|c|c|c|}
\hline Gorman, Lynn & 1 & $14 / 12 / 1973$ & Box 22 \\
\hline Graham & 1 & $16 / 12 / 1959$ & Box 23 \\
\hline Graham, Dr. Ronald & 1 & 27/07/1984 & Box 23 \\
\hline Guttmacher, Dr. & 2 & $14 / 05 / 1959$ & Box 24 \\
\hline Haggarty, James & 1 & $01 / 09 / 1952$ & Box 24 \\
\hline Hammond, C.E. & 1 & $30 / 10 / 1974$ & Box 24 \\
\hline Hancock, John & 1 & $10 / 09 / 1946$ & Box 24 \\
\hline Handler, Mike & 1 & $01 / 03 / 1954$ & Box 24 \\
\hline Hanley, John W. & 2 & $03 / 11 / 1972$ & Box 24 \\
\hline Harry, Engle & 3 & $04 / 01 / 1951$ & $\begin{array}{l}\text { Box } 25 \\
\text { Box } 73\end{array}$ \\
\hline Hart, Bill & 1 & $11 / 08 / 1975$ & Box 37 \\
\hline Hausner, Cliff & 1 & $19 / 01 / 2004$ & Box 25 \\
\hline Heils, Joseph & 1 & $11 / 08 / 1966$ & Box 25 \\
\hline Heiting, Hanna & 1 & $01 / 11 / 1991$ & Box 25 \\
\hline Hester, Dr. James & 2 & $16 / 04 / 1968$ & Box 25 \\
\hline Hey, Raymond A. & 1 & $12 / 02 / 1974$ & Box 25 \\
\hline Hicks, Barry & 1 & $02 / 11 / 1986$ & Box 25 \\
\hline Hipp, Francis & 1 & $14 / 10 / 1969$ & Box 25 \\
\hline Hirshfield, Alan J. & 4 & $06 / 08 / 1975$ & Box 26 \\
\hline Hiske, Maas & 3 & $29 / 12 / 1964$ & Box 26 \\
\hline Hoffman, Eric & 2 & $14 / 11 / 1984$ & Box 26 \\
\hline Hoffman, Ronna & 2 & $14 / 11 / 1984$ & Box 26 \\
\hline Horne, George & 1 & $08 / 10 / 1954$ & Box 27 \\
\hline Horowitz, Eli & 1 & $12 / 08 / 1975$ & Box 47 \\
\hline Huggard, E. Douglas & 2 & $23 / 03 / 1990$ & Box 27 \\
\hline Hurlbert, Allan & 1 & $10 / 04 / 1963$ & Box 27 \\
\hline Hurlburt, G.C. & 3 & $21 / 10 / 1974$ & Box 27 \\
\hline Israel, Robert & 2 & $23 / 08 / 1989$ & Box 28 \\
\hline J.B. & 2 & $15 / 04 / 1959$ & Box 28 \\
\hline Jacobson & 2 & $20 / 06 / 1966$ & Box 28 \\
\hline James, Nicol & 1 & $30 / 01 / 1979$ & Box 43 \\
\hline Jenkins, Suzanne & 1 & $24 / 06 / 1983$ & Box 28 \\
\hline Jensen, Oliver & 3 & $09 / 08 / 1974$ & Box 28 \\
\hline Johnson, C.W. & 2 & $19 / 01 / 1960$ & Box 29 \\
\hline Jones, B.F. III & 1 & $18 / 12 / 1952$ & Box 29 \\
\hline Jones, Edward & 1 & $10 / 01 / 1979$ & Box 29 \\
\hline Kaiser & 1 & $01 / 05 / 1951$ & Box 30 \\
\hline Kalish, Ursula & 1 & $25 / 05 / 1967$ & Box 30 \\
\hline Kapstein, John & 1 & $03 / 02 / 1967$ & Box 30 \\
\hline Karimer, James & 1 & $31 / 12 / 1963$ & Box 30 \\
\hline Karrien, Von Karl & 2 & $27 / 05 / 1958$ & Box 30 \\
\hline
\end{tabular}




\begin{tabular}{|c|c|c|c|}
\hline Katz, Karl & 1 & $29 / 04 / 1967$ & Box 30 \\
\hline Kearns, Warren & 1 & $17 / 11 / 1983$ & Box 47 \\
\hline Kebble, Van & 3 & $06 / 09 / 1948$ & Box 20 \\
\hline Kerns, Dick & 1 & $14 / 08 / 1975$ & Box 30 \\
\hline Kneeland, George J. & 1 & $24 / 04 / 1972$ & Box 31 \\
\hline Koetters, Ronald and Florence & 1 & $14 / 03 / 1983$ & Box 31 \\
\hline Kootz, Sam & 1 & $08 / 01 / 1958$ & Box 31 \\
\hline Korman, Marvin & 1 & $20 / 08 / 1975$ & Box 31 \\
\hline Krickorian, George & 2 & $01 / 07 / 1951$ & Box 32 \\
\hline Krikorian, George & 2 & $01 / 07 / 1951$ & Box 8 \\
\hline Kucharski, John & 1 & $18 / 01 / 1993$ & Box 32 \\
\hline Kupperman, Dr. & 1 & $09 / 07 / 1958$ & Box 32 \\
\hline Kurtz, Jill & 1 & $18 / 06 / 1990$ & Box 32 \\
\hline Lassiter, Ken & 1 & $29 / 03 / 1992$ & Box 33 \\
\hline Laurent, Robb & 2 & $22 / 04 / 1948$ & Box 33 \\
\hline Lawler & 1 & $01 / 05 / 1951$ & Box 33 \\
\hline Lawrence, Larry & 2 & $09 / 06 / 1986$ & Box 33 \\
\hline Lawrence, Ride Trentle Sr. & 2 & $22 / 08 / 1974$ & Box 33 \\
\hline Lawrence, William & $\begin{array}{l}1 \\
3\end{array}$ & $\begin{array}{l}28 / 03 / 1959 \\
17 / 03 / 1953\end{array}$ & Box 33 \\
\hline Lawson, A.T. & 3 & $11 / 12 / 1952$ & Box 33 \\
\hline Lecash, Leon & 1 & $20 / 12 / 1990$ & Box 33 \\
\hline Leeds, Larry & $\begin{array}{l}1 \\
1\end{array}$ & $\begin{array}{l}11 / 07 / 1977 \\
12 / 07 / 1977\end{array}$ & Box 33 \\
\hline Leether, Jack & 2 & $06 / 07 / 1974$ & Box 33 \\
\hline Len, Commissioner James & 1 & 06/01/1970 & Box 34 \\
\hline Levy, Gerard & $\begin{array}{l}1 \\
4\end{array}$ & $\begin{array}{l}16 / 10 / 1977 \\
18 / 06 / 1971\end{array}$ & Box 34 \\
\hline Levy, Gerard & 1 & $16 / 10 / 1977$ & Box 34 \\
\hline Levy, Joseph & 1 & $16 / 10 / 1977$ & Box 34 \\
\hline Ludzin, Earle & 2 & $01 / 08 / 1952$ & Box 35 \\
\hline MacMillian, RT. Hon. & 1 & $01 / 03 / 1954$ & Box 36 \\
\hline Mahoney, Margaret & 1 & $28 / 05 / 1985$ & Box 36 \\
\hline Mailcoat, Philip & 2 & $12 / 08 / 1964$ & Box 36 \\
\hline Marcos, George & 1 & $05 / 07 / 1941$ & Box 36 \\
\hline Mark, Dr. Lawrence & 1 & $29 / 10 / 1975$ & Box 37 \\
\hline Markhel & 2 & $12 / 11 / 1951$ & Box 37 \\
\hline Marks, Ruth & 1 & $11 / 06 / 1968$ & Box 37 \\
\hline Marsh, John & 1 & $24 / 03 / 1966$ & Box 37 \\
\hline Martinez, Romeo & 1 & $18 / 06 / 1971$ & Box 37 \\
\hline Mathers, Laverne & 2 & $29 / 02 / 1948$ & Box 33 \\
\hline Maynard, Dr. & 1 & $01 / 02 / 1960$ & Box 38 \\
\hline
\end{tabular}




\begin{tabular}{|c|c|c|c|}
\hline Mazzucca, Estherina & 2 & $23 / 01 / 1983$ & Box 38 \\
\hline Mc Cormack, Edwin J. & 1 & $09 / 01 / 1970$ & Box 38 \\
\hline McCleary, Dan & 1 & $12 / 11 / 1985$ & Box 38 \\
\hline McCollough, Peter & 1 & $19 / 11 / 1973$ & Box 38 \\
\hline McCormack, Edwin J. & 1 & $09 / 01 / 1970$ & Box 38 \\
\hline McCray, Gordon & 2 & $01 / 09 / 1949$ & Box 38 \\
\hline McDermott, Edward A & 1 & 07/07/1965 & Box 38 \\
\hline McGannon, D.H. & 1 & $29 / 10 / 1974$ & Box 38 \\
\hline McWhinney, John & 3 & $24 / 01 / 1976$ & Box 38 \\
\hline Mercier, Louis & $\begin{array}{l}1 \\
1\end{array}$ & $\begin{array}{l}11 / 01 / 1956 \\
25 / 01 / 1956\end{array}$ & Box 38 \\
\hline Michaels, Lilly & 4 & $27 / 05 / 1959$ & $\begin{array}{l}\text { Box } 38 \\
\text { Box } 74\end{array}$ \\
\hline Minskoff, Myron & 4 & $20 / 04 / 1967$ & Box 39 \\
\hline Mitchell, Jean & 2 & $02 / 02 / 1954$ & Box 39 \\
\hline Mitchell, John H. & 1 & $13 / 08 / 1975$ & Box 39 \\
\hline Monroe, George & 2 & $14 / 08 / 1978$ & Box 40 \\
\hline Morgan, Weld & 2 & $27 / 12 / 1973$ & Box 41 \\
\hline Morris, Myra & 1 & $18 / 10 / 1974$ & Box 41 \\
\hline Morse, W.S. & 1 & $05 / 12 / 1969$ & Box 41 \\
\hline Mortimer, C.D. & 1 & $14 / 12 / 1954$ & Box 41 \\
\hline Mossberg, Dr. David & 1 & $30 / 04 / 1964$ & Box 41 \\
\hline Mr. Beech & $\begin{array}{l}1 \\
1\end{array}$ & $\begin{array}{l}11 / 09 / 1957 \\
08 / 10 / 1957\end{array}$ & Box 19 \\
\hline Murrin, T.J. & 1 & $22 / 10 / 1974$ & Box 41 \\
\hline Newman, David & $\begin{array}{l}1 \\
3\end{array}$ & $\begin{array}{l}21 / 08 / 1977 \\
20 / 10 / 1985\end{array}$ & Box 43 \\
\hline Nichols, Alexander L. & 1 & $07 / 11 / 1980$ & Box 43 \\
\hline Nielsen, Helmar & 4 & $15 / 11 / 1982$ & Box 43 \\
\hline Novack, Gloria & 3 & $15 / 05 / 1964$ & Box 44 \\
\hline Novak, Barbara & 3 & $10 / 10 / 1983$ & Box 44 \\
\hline Noyes, Blancke & 1 & $06 / 01 / 1969$ & Box 44 \\
\hline O'Flaherty, Kevin & 1 & $25 / 07 / 2001$ & Box 44 \\
\hline Ollman, Benn & 2 & $05 / 10 / 1982$ & Box 44 \\
\hline Open, John R. & 2 & $02 / 12 / 1982$ & Box 10 \\
\hline Page, John H. & 1 & 23/03/1966 & Box 45 \\
\hline Parish, P.S. & 1 & $14 / 01 / 1959$ & Box 45 \\
\hline Parker, Ann & 2 & $30 / 01 / 1942$ & Box 45 \\
\hline Parlee, James & 1 & $28 / 05 / 1964$ & Box 45 \\
\hline Percopo, Michael W. & 1 & $30 / 10 / 1975$ & Box 46 \\
\hline Perlman, Dr. Phillip & 1 & $24 / 10 / 1990$ & Box 46 \\
\hline
\end{tabular}




\begin{tabular}{|c|c|c|c|}
\hline Peter, John & 1 & $30 / 12 / 1969$ & Box 46 \\
\hline Pierce, Danny & 2 & $01 / 04 / 1962$ & Box 46 \\
\hline Poling, Dr. Daniel & 1 & $03 / 04 / 1956$ & Box 47 \\
\hline Polk, Dr. Charles & 1 & $25 / 04 / 1989$ & Box 47 \\
\hline Polk, Lewis & 1 & $08 / 01 / 1969$ & Box 47 \\
\hline Pomerance, Dr. Julius & 1 & 08/07/1958 & Box 47 \\
\hline Poole, Mary & 1 & $10 / 04 / 1975$ & Box 47 \\
\hline Pope, Virginia & 4 & $01 / 10 / 1951$ & Box 47 \\
\hline Porras, Arthur & 1 & $01 / 08 / 1993$ & Box 47 \\
\hline Porras, Sandy & 1 & $01 / 08 / 1993$ & Box 47 \\
\hline Porter, Milton & 1 & $17 / 11 / 1983$ & Box 47 \\
\hline Powers, Dr. Eric & 1 & $17 / 12 / 1985$ & Box 47 \\
\hline Price, Peter & 1 & $10 / 03 / 1981$ & Box 47 \\
\hline Prince, Philip & 2 & $05 / 11 / 1982$ & Box 47 \\
\hline Quillian, Kirk J. & 2 & 07/06/1987 & Box 47 \\
\hline Rawleigh Warner Jr. & $\begin{array}{l}1 \\
1 \\
1 \\
1\end{array}$ & $\begin{array}{l}11 / 12 / 1973 \\
11 / 12 / 1978 \\
17 / 01 / 1979 \\
24 / 01 / 1980\end{array}$ & Box 63 \\
\hline Reavis, J.W. & 2 & $22 / 12 / 1952$ & Box 48 \\
\hline Reed, Elizabeth & 1 & 09/03/1971 & Box 48 \\
\hline Reisenfeld, Ellen & 2 & $20 / 01 / 1953$ & Box 48 \\
\hline Remis, Harold & 2 & 05/05/1977 & Box 48 \\
\hline Remis, Mildred & 1 & $05 / 05 / 1977$ & Box 48 \\
\hline Rengel, J.C. & 1 & $16 / 10 / 1974$ & Box 48 \\
\hline Resony, John A. & 1 & $08 / 01 / 1975$ & Box 48 \\
\hline Rex, Barbara & 1 & $05 / 03 / 1962$ & Box 48 \\
\hline Ribicoff, Jane & 1 & $01 / 07 / 1965$ & Box 48 \\
\hline Richards, Harold & 2 & $04 / 12 / 1959$ & Box 48 \\
\hline Richardson, Linda & 1 & $25 / 11 / 1980$ & Box 48 \\
\hline Rolli, Dr. Elaine & 2 & $24 / 06 / 1958$ & Box 49 \\
\hline Rome, Florence & 1 & $22 / 09 / 1970$ & Box 49 \\
\hline Rose, Sidney & 1 & $14 / 12 / 1973$ & Box 50 \\
\hline Rosen, Dan & 1 & $01 / 02 / 1985$ & Box 50 \\
\hline Roslyn Richards & 2 & $29 / 09 / 1948$ & Box 48 \\
\hline Rosseau, Theodore & 2 & $29 / 01 / 1970$ & Box 50 \\
\hline Rothman, David & $\begin{array}{l}2 \\
1\end{array}$ & $\begin{array}{l}03 / 06 / 1999 \\
30 / 01 / 2002\end{array}$ & Box 50 \\
\hline Rowe, Ed & 2 & $10 / 02 / 1971$ & Box 51 \\
\hline Rubin, Esther & 1 & $08 / 05 / 1982$ & Box 51 \\
\hline Russell & 1 & $01 / 12 / 1951$ & Box 51 \\
\hline Salizard, Leo & 2 & $04 / 07 / 1963$ & Box 51 \\
\hline Sax, Samuel William & 2 & $24 / 03 / 1976$ & Box 52 \\
\hline
\end{tabular}




\begin{tabular}{|c|c|c|c|}
\hline Schapiro, James & 1 & $13 / 01 / 1964$ & Box 52 \\
\hline Scharffenberger, George & 1 & $14 / 12 / 1983$ & Box 52 \\
\hline Schaub, J. Stephen & 1 & $09 / 01 / 1970$ & Box 52 \\
\hline Schmitz, Renate & 2 & $27 / 01 / 1965$ & Box 52 \\
\hline Schnall, Mel & 1 & $02 / 10 / 1958$ & Box 52 \\
\hline Schrieber, R.S. & 1 & $14 / 01 / 1959$ & Box 52 \\
\hline Schulhof, Ruda & 1 & $29 / 06 / 1965$ & Box 52 \\
\hline Schuster, Dr. George & 2 & $08 / 09 / 1948$ & Box 52 \\
\hline Seaborg, Dr. & 1 & $14 / 06 / 1948$ & Box 52 \\
\hline Seay, E.W. & 1 & $30 / 10 / 1974$ & Box 52 \\
\hline Segy, L. & 1 & $01 / 01 / 1952$ & Box 54 \\
\hline Shaked, Haim & 1 & $19 / 11 / 2002$ & Box 52 \\
\hline Shapiro, Eli & 1 & $08 / 01 / 1975$ & Box 54 \\
\hline Sheret, M. & 2 & $02 / 04 / 1949$ & Box 54 \\
\hline Silver, Dr. & 2 & $10 / 07 / 1958$ & Box 55 \\
\hline Simmonds, Geoffrey R. & 1 & $19 / 03 / 1975$ & Box 55 \\
\hline Singer, Steven & 1 & $13 / 08 / 1974$ & Box 55 \\
\hline Skir, Leo & 2 & $03 / 01 / 1965$ & Box 55 \\
\hline Small, Marvin & 1 & $13 / 03 / 1972$ & Box 55 \\
\hline Smith, Andrew & 4 & 03/08/1994 & Box 55 \\
\hline Smith, David & 5 & $20 / 10 / 1957$ & Box 55 \\
\hline Smith, Richard & 2 & $23 / 06 / 1966$ & Box 55 \\
\hline Snaith, William & 2 & $27 / 03 / 1959$ & Box 56 \\
\hline Sonnenberg, Hilda & 1 & $02 / 08 / 1964$ & Box 5 \\
\hline Spencer, William & 1 & $17 / 12 / 1976$ & Box 56 \\
\hline Sperry, Paul & $\begin{array}{l}2 \\
1\end{array}$ & $\begin{array}{l}27 / 04 / 1984 \\
16 / 02 / 1988\end{array}$ & Box 56 \\
\hline Sproul, Dr. & 1 & $21 / 01 / 1960$ & Box 56 \\
\hline Stanley, Dr. Wende & 1 & $05 / 06 / 1948$ & Box 57 \\
\hline Staughton, Kathleen & 1 & $28 / 07 / 1993$ & Box 57 \\
\hline Steinberg, Dr. David & 1 & $28 / 05 / 1985$ & Box 57 \\
\hline Steinman, Dr. Anne & 1 & $07 / 11 / 1973$ & Box 57 \\
\hline Stephenson, Garrett & 1 & $13 / 12 / 1972$ & Box 57 \\
\hline Sterling, James & 1 & $24 / 10 / 1981$ & Box 57 \\
\hline Sterling, Lucretia & 1 & $24 / 10 / 1981$ & Box 57 \\
\hline Stern, Cassis & 2 & $20 / 10 / 1964$ & Box 58 \\
\hline Sterne, Joel & 1 & $28 / 03 / 1977$ & Box 58 \\
\hline Stevens, Robert & 1 & $09 / 05 / 1976$ & Box 58 \\
\hline Stevens, W. Clay & 2 & 09/01/1970 & Box 58 \\
\hline Sullivan, Walter & 2 & $04 / 02 / 1958$ & Box 59 \\
\hline
\end{tabular}




\begin{tabular}{|c|c|c|c|}
\hline Tandy, Anne & $\begin{array}{l}1 \\
3\end{array}$ & $\begin{array}{l}15 / 10 / 1973 \\
16 / 10 / 1973\end{array}$ & Box 59 \\
\hline Tatum, Edmond & 1 & $03 / 06 / 1964$ & Box 60 \\
\hline Taylor, Adrian & 1 & $29 / 06 / 1968$ & Box 60 \\
\hline Temkin, Jeremy & 1 & $18 / 06 / 1990$ & Box 32 \\
\hline Thompson, David & 4 & $15 / 09 / 1961$ & Box 60 \\
\hline Tobin, Charles & 1 & $02 / 01 / 1949$ & Box 60 \\
\hline Todd, David & 1 & $14 / 05 / 1969$ & Box 60 \\
\hline Todd, Foster F. & 2 & $23 / 03 / 1966$ & Box 60 \\
\hline Turl, Reverand Stanley & 2 & $18 / 05 / 1978$ & Box 2 \\
\hline Upjohn, Dr. LN & 1 & $01 / 11 / 1949$ & Box 62 \\
\hline Van Vector, David & 1 & $10 / 01 / 1952$ & Box 62 \\
\hline Victoria, Fred & 1 & $13 / 12 / 1972$ & Box 62 \\
\hline Walker, Hudson & 1 & $11 / 10 / 1965$ & Box 62 \\
\hline Wallace, Carol & 1 & 14/03/1957 & Box 63 \\
\hline Walod, Paul & 2 & $05 / 01 / 1956$ & Box 52 \\
\hline Warf, Victor & 1 & $27 / 04 / 1989$ & Box 63 \\
\hline Waterman, R.Lee & 1 & $18 / 11 / 1965$ & Box 63 \\
\hline Weiss, Edward & 3 & $22 / 06 / 1965$ & Box 64 \\
\hline Weiss, Steven S. & 1 & $01 / 01 / 1944$ & Box 64 \\
\hline Weissberg, Dan & 1 & $08 / 08 / 1964$ & Box 64 \\
\hline Weissenberg, Sigi & 2 & $10 / 07 / 1956$ & Box 64 \\
\hline Weitzen, Dr. Hyman & 2 & $31 / 12 / 1964$ & Box 64 \\
\hline White, Frank & 1 & $19 / 12 / 1951$ & Box 65 \\
\hline White, William & 1 & $14 / 01 / 1955$ & Box 65 \\
\hline Whitney, John (Jack) & 4 & $06 / 10 / 1943$ & $\begin{array}{l}\text { Box } 65 \\
\text { Box } 85\end{array}$ \\
\hline Wigler, Dr. Michael & 1 & $16 / 08 / 1984$ & Box 65 \\
\hline Wilcox, G.L. & 1 & $11 / 10 / 1974$ & Box 65 \\
\hline Wilson, C.E. & 1 & $21 / 06 / 1960$ & Box 65 \\
\hline Winston, Walter B. & 1 & $23 / 09 / 1976$ & Box 65 \\
\hline Wipple, Dr. Fred & 2 & $03 / 05 / 1958$ & Box 65 \\
\hline Wise, Howard & 3 & $04 / 07 / 1966$ & Box 65 \\
\hline Wolf, Vincente & 3 & $23 / 11 / 1982$ & Box 65 \\
\hline Wolfington, J.E. & 1 & $06 / 12 / 1969$ & Box 66 \\
\hline Woolf, Dr. Harry & 1 & $22 / 02 / 1991$ & Box 66 \\
\hline Wylie, Jeff & 1 & $30 / 11 / 1962$ & Box 66 \\
\hline Yamasaki, M. & 2 & $24 / 06 / 1960$ & Box 66 \\
\hline Yorke, Jones & 2 & $12 / 07 / 1976$ & Box 66 \\
\hline Zachary, Frank & $\begin{array}{l}1 \\
2\end{array}$ & $\begin{array}{l}01 / 11 / 1984 \\
07 / 01 / 1992\end{array}$ & Box 66 \\
\hline
\end{tabular}


Zoroff, Len

\begin{tabular}{|l|l|}
1 & $17 / 10 / 1964$
\end{tabular}

Box 66 


\section{Selected Associated Collections}

The Arnold Newman Archive/The Harry Ransom Center

$21^{\text {st }}$ Austin, Texas

United States of America

78712

(512) 471-8944

George Eastman House: International Museum of Photography and Film

900 East Avenue, Rochester, NY

United States of America

14607

(585) 271-3361

\section{National Gallery of Canada}

380 Sussex Drive, Ottawa, ON

Canada

K1N 9N4

(613) 990-1985

The Museum of Modern Art

11 West, $53^{\text {rd }}$ Street, New York City, NY

United States of America

10019

(212) 708-9400

The Metropolitan Museum of Art

$10005^{\text {th }}$ Ave, New York City, NY

United States of America

10028

(212) 535-7710

The Victoria and Albert Museum

Cromwell Road, London

United Kingdom

+4420 7942-2000

\section{Philadelphia Museum of Art}

2600 Benjamin Franklin Parkway, Philadelphia, PA

United States of America

19130

(215) 763-8100

National Gallery of Australia

Parkes PI, Canberra ACT 2600

Australia

+61262406411 
International Centre of Photography

1133 Avenue of the Americas, \#1 A, New York City, NY

United States of America

10036

(212) 857-0000

Tel Aviv Museum

שדרות שאול המלך Tel Aviv

Israel

64239

972 3-607-7020 


\section{Sources}

"Glossary." UofT Archives \& Records Management Services. Web. 30 June 2013.

$<$ http://www.library.utoronto.ca/utarms/info/glossary.html>

"EAD Best Practices." Library of Congress Finding Aids.Library of Congress, Web. 30 June 2013.

$<$ http://www.loc.gov/rr/ead/lcp/>

"Style Manual for Archival Finding Aids for the University of Wisconsin Digital Collections

Center." University of Winsoncin (2002)

Archives of American Art. "Artists Look Like This." The Quarterly Bulliton 2.4, 3.1, 3.2, 3.3, 3.4:

Ben-David, Calaev. The Jerusalem Report (Feb 24, 1994): 42.

Campbell, Bryn. Exploring Photography. New York: Hudson Hills, 1979.

Cox, Richard. "Revisiting the Archival Finding Aid." Journal of Archival Organization 5.4 (2008): 532.

Crane, Arnold H. On the Other Side of the Camera. Köln: Könemann, 1995.

Crist, Steve. The Contact Sheet. [Los Angeles, Calif.]: AMMO, 2009.

Danziger, James, and Barnaby Conrad. Interviews with Master Photographers. New York: Paddington, 1977.

Eastman Kodak Corporation, prod. "Techniques of the Masters. Arnold Newman and Andreas Heumann." Kodak Business Television.KBTV. Rochester, New York, 1990. Television.

Farber, Robert. Natural Beauty: Farber Nudes. London: Merrell, 2001.

Fundacion Pedro Barrie De La Maza, Conde De Fenosa, ed. El Regalo De Newman 50 Anos De Fotografia. Coruna: Tapa Blanda, 1998.

Gallery Systems. 30 June 2013. <http://www.gallerysystems.com/contact>.

Great Photographers. New York, NY: Time-Life, 1971.

Gruber, L. Fritz. Famous Portraits. New York: Ziff-Davis Pub., 1960.

Hennessey, Lisa C. The Mark A. Freeman Collection of World War II Photographs At George Eastman House. Diss. Ryerson University, 2007. Toronto, Ontario: Ryerson University, 2007.

Newman, Arnold. The Arnold Newman Sitting Book. Arnold Newman Archives, Web. $<\mathrm{http} / / /$ www.arnoldnewmanarchive.com/index.php?option=com_content\&view=article\&id=151\&Itemid $=33>$ 
Jay, Bill. Photographers Photographed. Salt Lake City: Peregrine Smith, 1983.

Lasala, Anthony. "Arnold Newman." Photo District News [New York City] Aug. 1998, 18th ed., sec. 8.

Loengard, John. Celebrating the Negative. New York: Arcade Pub., 1994.

Lyons, Nathan, Jean Sutherland. Boggs, James Borcoman, and Beaumont Newhall.Photography in the 20th Century: An Exhibition Circulated in Canada by the National Gallery of Canada. New York: [s.n.], 1967.

Newman, Arnold. The Arnold Newman Sitting Book. Arnold Newman Archives, Web.

$<$ http://www.arnoldnewmanarchive.com/index.php?option=com_content\&view=article\&id=151\&Itemid $=33>$

Newman, Arnold. Artists, Portraits from Four Decades. Boston: New York Graphic Society, 1980.

Newman, Arnold. Faces USA. Garden City, NY: American Photographic Book Pub., 1978.

Newman, Arnold. The Great British. Boston: New York Graphic Society, 1979.

Newman, Arnold. One Mind's Eye: The Portraits and Other Photographs of Arnold Newman. Boston: D. R. Godine, 1974.

Newman, Arnold, and Bruce Weber. Arnold Newman in Florida. Boston, MA: D.R. Godine in Association with Norton Gallery of Art, 1988.

Newman, Arnold, Robert Craft, and Igor Stravinsky. Bravo Stravinsky. Cleveland: World Pub., 1967.

Newman, Arnold, Ron Kurtz, Howard Greenberg, and Philip Brookman. Arnold Newman: The Early Work. Göttingen: Steidl, 2008.

Morning Edition: 1. Washington, D.C.: National Public Radio. 2000. Broadcast

Ollman, Arthur, and Arnold Newman. Arnold Newman: Five Decades. San Diego: Harcourt Brace Jovanovich Publ., 1986.

Pollack, Peter. The Picture History of Photography: From the Earliest Beginnings to the Present Day. New York: H.N. Abrams, 1969.

Stuchell, Lance. "Creating Finding Aids at the Benson Ford Research Center." Benson Ford Research Centre 1.12012.

Szarkowski, John. The Photographer's Eye. New York: Museum of Modern Art; Distributed by Doubleday, Garden City, N.Y., 1966.

Szarkowski, John. Looking at Photographs; 100 Pictures from the Collection of the Museum of Modern Art. New York: Distributed by New York Graphic Society, Greenwich, Conn, 1973 